

\title{
BUKU AJAR \\ ADMINISTRASI PEMERINTAH DAERAH
}

\author{
Oleh \\ Ilmi Usrotin Choiriyah, M.AP \\ Lailul Mursyidah, M.AP
}

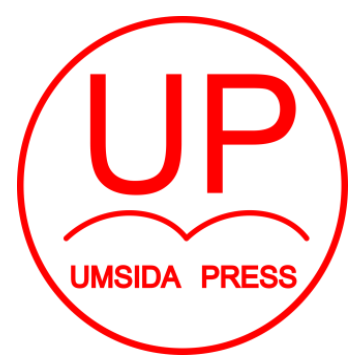

Diterbitkan oleh: UMSIDA Press

UNIVERSITAS MUHAMMADIYAH SIDOARJO

2020 


\section{BUKU AJAR \\ ADMINISTRASI PEMERINTAH DAERAH}

\section{Penulis:}

Ilmi Usrotin Choiriyah, M.AP

Lailul Mursyidah, M.AP

\section{ISBN :}

978-623-6833-51-3

\section{Editor:}

Dr. Isnaini Rodiyah, M.Si.

Kukuh Sinduwiatmo, M.Si

\section{Design Sampul dan Tata Letak:}

Mochammad Nashrulloh, S.Pd.

Amy Yoga Prajati, S.Kom.

Penerbit:

UMSIDA Press

Anggota IKAPI No.218 Anggota Luar Biasa/JTI/2019

Anggota APPTI No. 0020181092017

Redaksi

Universitas Muhammadiyah Sidoarjo

Jl. Mojopahit No 666B

Sidoarjo, Jawa Timur

Cetakan Pertama, November 2020

CHak Cipta dilindungi undang undang

Dilarang memperbanyak karya tulis ini dengan sengaja, tanpa ijin tertulis dari penerbit. 


\section{KATA PENGANTAR}

Puji syukur kami panjatkan kehadirat Allah SWT, atas rahmat dan karunia-Nya Buku Ajar Pemerintah Daerah dapat diselesaikan dengan baik dan tanpa halangan yang berarti. Shalawat dan salam selalu kami sampaikan kepada junjungan Nabi Muhammad SAW.

Tim penulis mengucapkan terimakasih kepada:

1. Wisnu Panggah Setiyono, SE, M.Si, Ph.D., Dekan Fakultas Bisnis, Hukum dan Ilmu Sosial yang memberikan arahan dan motivasi kepada penulis dalam menyelesaikan buku ajar ini.

2. Lailul Mursyidah, M.AP, Kaprodi Administrasi Publik yang telah memberikan dukungan untuk menyusun buku ajar ini.

3. Rekan-rekan dosen pengampu Mata Kuliah Pemerintah Daerah di Prodi Administrasi Publik yang telah berbagi pengalaman dalam mengampu mata kuliah tersebut.

Saran dan kritik sangat penulis harapkan untuk mewujudkan buku ajar Pemerintah Daerah yang lebih baik dan tentunya sesuai dengan amanat peraturan yang berlaku. Terimakasih.

Tim Penulis 


\section{DAFTAR ISI}

HALAMAN SAMPUL............................................. ii

KATA PENGANTAR ............................................. ii

DAFTAR ISI ....................................................... iii

BAB I. Perkembangan administrasiPemerintah daerah di Indonesia
A. Deskripsi Singkat
1
B. Kompetensi Dasar ................................................. 2
C. Indikator ................................................................ 2

1.1 Administrasi Pemerintah Daerah Pada Masa

Penjajahan Belanda .................................... 3

1.2 Administrasi Pemerintah Daerah Pada Masa Penjajahan Jepang..................................... 5

1.3 Administrasi Pemerintah Daerah Pada Masa Setelah Kemerdekaan ................................ 6

D. Quiz ................................................................. 22

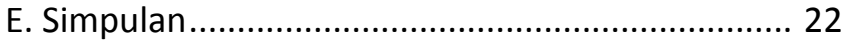

F. Daftar Pustaka ..................................................... 23

BAB II. Pengantar Desentralisasi

A. Deskripsi Singkat ............................................. 25

B. Kompetensi Dasar ............................................... 26

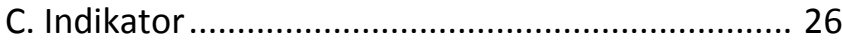

2.1 Teori Utama Desentralisasi .......................... 26

2.2 Rentang Perdebatan teori Desentralisasi:

Rondinelli Vs Slater.................................... 43

2.3 Rentang Pengertian Desentralisasi ............... 50

2.4 Derajat Desentralisasi .................................. 55

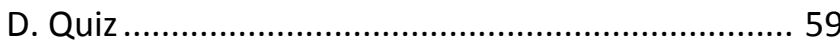




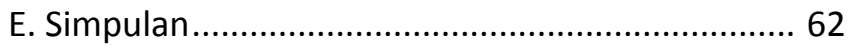

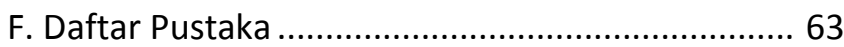

BAB III. Organisasi Pemerintah Daerah

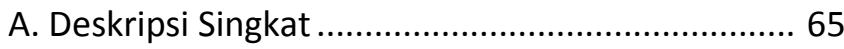

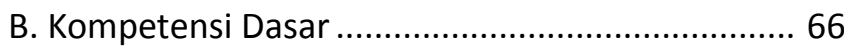

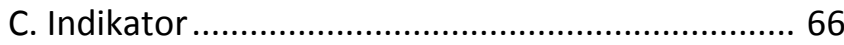

3.1 Pembentukan Daerah dan Kriterianya.......... 66

3.2 Bantuk dan Sasaran Pemerintah Daerah ...... 69

3.3 Kepegawaian Pemerintah Daerah ................ 76

3.4 Rekrutmen Pegawai Daerah .......................... 81

3.5 Pembinaan dan Pengembangan Pegawai

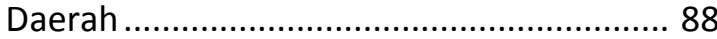

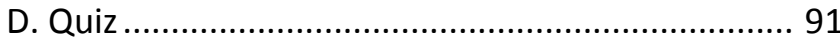

E. Simpulan........................................................ 92

F. Daftar Pustaka ..................................................... 93

BAB IV. Pembagian Kekuasaan Ke Daerah

A. Deskripsi Singkat .................................................. 94

B. Kompetensi Dasar .................................................. 95

C. Indikator .............................................................. 95

4.1 Perlunya Pembagian Kekuasaan .................... 95

4.2 Cara Pembagian Kekuasaan .......................... 98

4.3 Pembagian Kekuasaan Berdasarkan proses.. 99

4.4 Pembagian Kekuasaan Berdasarkan

Pembagian Fungsi ..................................... 101

4.5 Hubungan Real Division Of Power (ADP)

dengan Capital Division Of Power (CDP) ... 103

4.6 Hubungan Pembagian Kekuasaan

Pemerintah dengan Non Pemerintah ...... 105

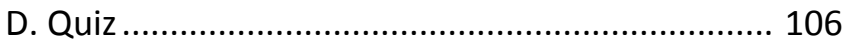

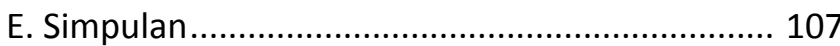

F. Daftar Pustaka ................................................... 109 
BAB V. Keuangan Daerah

A. Deskripsi Singkat .......................................... 110

B. Kompetensi Dasar ........................................... 110

C. Indikator ............................................................ 111

5.1 Sumber Pendapatan Asli Daerah (PAD) ...... 111

5.2 Sumber Pengeluaran................................ 113

5.3 Pengelolaan Keuangan Daerah .................. 116

5.4 Pemegang Kekuasaan Pengelolaan

Keuangan Daerah .................................. 120

5.5 Pejabat Pengelola Keuangan Daerah ......... 122

5.6 Proses Perencanaan dan penganggaran

Keuangan Daerah ................................... 124

5.7 Pelaksanaan Anggaran pendapatan dan

Belanja Daerah (APBD) ............................ 126

5.8 Kebijakan Penganggaran Terkait

Belanja dalam APBD ............................. 127

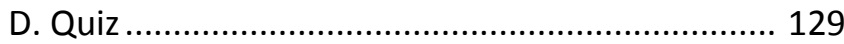

E. Simpulan....................................................... 130

F. Daftar Pustaka ................................................... 131

\section{DAFTAR PUSTAKA}

BIODATA PENULIS 


\section{BATANG TUBUH DAN \\ SUB-CAPAIAN PEMBELAJARAN MATA KULIAH}

\begin{tabular}{|c|c|}
\hline BAB & Sub-Capaian Pembelajaran Mata Kuliah \\
\hline $\begin{array}{l}\text { BAB I } \\
\text { PERKEMBA- } \\
\text { NGAN } \\
\text { ADMINISTRASI } \\
\text { PEMERINTAH } \\
\text { DAERAH DI } \\
\text { INDONESIA }\end{array}$ & $\begin{array}{l}\text { 1. Mahasiswa mampu memahami pemerintah } \\
\text { daerah pada masa penjajahan Belanda. } \\
\text { 2. Mahasiswa mampu memahami administrasi } \\
\text { pemerintah daerah pada masa penjajahan Jepang. } \\
\text { 3. Mahasiswa mampu memahami administrasi } \\
\text { pemerintah daerah pada masa setelah } \\
\text { Kemerdekaan }\end{array}$ \\
\hline $\begin{array}{l}\text { BAB II } \\
\text { PENGANTAR } \\
\text { DESENTRALI- } \\
\text { SASI }\end{array}$ & $\begin{array}{l}\text { 1. Mahasiswa mampu memahami teori utama } \\
\text { desentralisasi } \\
\text { 2. Mahasiswa mampu membandingkan rentang } \\
\text { perdebatan teori desentralisasi: Rondinelli vs } \\
\text { Slater } \\
\text { 3. Mahasiswa mampu membandingkan rentang } \\
\text { pengertian desentralisasi } \\
\text { 4. Mahasiswa mampu mengidentifikasi derajat } \\
\text { desentralisasi }\end{array}$ \\
\hline $\begin{array}{l}\text { BAB III } \\
\text { ORGANISASI } \\
\text { PEMERINTAH } \\
\text { DAERAH }\end{array}$ & $\begin{array}{l}\text { 1. Mahasiswa mampu mengidentifikasi } \\
\text { pembentukan daerah dan kriterianya; bentuk dan } \\
\text { sasaran pemerinah daerah; kepegawaian } \\
\text { pemerintah daerah; rekrutmen, pembinaan, dan } \\
\text { pengembangan pegawai daerah } \\
\text { 2. Mahasiswa mampu mengaplikasikan konsep } \\
\text { organisasi pemerintah daerah pada kasus-kasus di } \\
\text { daerah }\end{array}$ \\
\hline $\begin{array}{l}\text { BAB IV } \\
\text { PEMBAGIAN } \\
\text { KEKUASAAN KE } \\
\text { DAERAH }\end{array}$ & $\begin{array}{l}\text { 1. Mahasiswa mampu mengidentifikasi perlunya } \\
\text { pembagian kekuasaan dan cara pembagian } \\
\text { kekuasaan }\end{array}$ \\
\hline
\end{tabular}




\begin{tabular}{|l|l|}
\hline & $\begin{array}{l}\text { 2. Mahasiswa mampu membandingkan pembagian } \\
\text { kekuasaan berdasarkan proses dan fungsi } \\
\text { Bab V }\end{array}$ \\
$\begin{array}{l}\text { KEUANGAN } \\
\text { DAERAH }\end{array}$ & $\begin{array}{l}\text { 1. Mahasiswa mampu mengaplikasikan studi kasus } \\
\text { pendapatan daerah, sumber pengeluaran daerah, } \\
\text { pengelolaan keuangan daerah } \\
\text { Mahasiswa mampu mengidentifikasi pemegang } \\
\text { kekuasaan pengelolaan keuangan daerah dan } \\
\text { pejabat pengelola keuangan daerah } \\
\text { Mahasiswa mampu mengaplikasikan studi kasus } \\
\text { pengelolaan keuangan daerah }\end{array}$ \\
\hline
\end{tabular}




\section{BAB I}

\section{Perkembangan Administrasi Pemerintah Daerah di Indonesia}

\section{A. Deskripsi Singkat}

Indonesia merupakan sebuah negara yang wilayahnya terbagi atas daerah-daerah provinsi. Daerah provinsi itu dibagi lagi atas daerah kabupaten dan daerah kota. Setiap daerah provinsi, daerah kabupaten, dan daerah kota mempunyai pemerintahan daerah yang diatur dengan undang-undang. Pemerintahan Daerah adalah penyelenggaraan urusan pemerintahan oleh Pemerintah Daerah dan DPRD menurut asas otonomi dan tugas pembantuan dengan prinsip otonomi seluas-luasnya dalam sistem dan prinsip Negara Kesatuan Republik Indonesia sebagaimana dimaksud dalam UUD 1945.

Pemerintahan daerah provinsi, kabupaten, dan kota memiliki Dewan Perwakilan Rakyat Daerah yang anggota-anggotanya dipilih melalui pemilihan umum. Gubernur, Bupati, dan Walikota masing-masing sebagai Kepala Pemerintah Daerah Provinsi, Kabupaten, dan Kota dipilih secara demokratis. Hubungan wewenang antara pemerintah pusat dan pemerintah daerah provinsi, kabupaten, dan kota atau antara provinsi dan kabupaten dan kota, diatur dengan undangundang dengan memperhatikan kekhususan dan keragaman daerah. Hubungan keuangan, pelayanan umum, pemanfatan sumber daya alam dan sumber daya lainnya antara pemerintah pusat dan pemerintahan daerah diatur dan dilaksanakan secara adil dan selaras berdasarkan undang-undang.

Negara mengakui dan menghormati satuan-satuan pemerintahan daerah yang bersifat khusus atau bersifat istimewa yang diatur dengan undang-undang. Negara mengakui dan menghormati kesatuan-kesatuan masyarakat hukum adat serta hak- 
hak tradisonalnya sepanjang masih hidup dan sesuai dengan perkembangan masyarakat dan prinsip Negara Kesatuan Republik Indonesia, yang diatur dalam undang-undang.

Pada Bab I ini mempelajari tentang perkembangan administrasi pemerintah daerah di Indonesia. Administrasi pemerintah daerah di Indonesia mengalami perubahan sejak jaman penjajahan Belanda, penjajahan Jepang, dan masa setelah kemerdekaan.

\section{B. Kompetensi Dasar}

Setelah perkuliahan selesai diharapkan mahasiswa mampu dan memahami perkembangan administrasi pemerintah daerah di Indonesia.

\section{Indikator}

1. Mahasiswa mampu mengetahui dan mengidentifikasi administrasi pemerinth daerah pada masa penjajahan Belanda

2. Mahasiswa mampu mengetahui dan mengidentifikasi administrasi pemerinth daerah pada masa penjajahan Jepang

3. Mahasiswa mampu mengetahui dan mengidentifikasi administrasi pemerintah daerah pada masa setelah Kemerdekaan.

Berikut adalah proses perkembangan administrasi pemerintah daerah di Indonesia dari masa penjajahan hingga setelah kemerdekaan. 
Administrasi pemerintah daerah pada masa setelah Kemerdekaan
Administrasi pemerintah daerah pada masa penjajahan Belanda
Administrasi

pemerintah daerah pada masa penjajahan Jepang

Gambar 1.1.

Tren Perkembangan Administrasi Pemerintah Daerah di Indonesia

\subsection{Administrasi pemerintah daerah pada masa penjajahan Belanda}

Awal perkembangan administrasi pemerintah daerah di Indonesia yaitu pada jaman Hindia-Belanda yang mana pada saat itu Indonesia mempercayai pemahaman sentralistik. Dimana pemahaman tersebut semua kegiatan kepemimpinannya dikepalai oleh seorang Gubernur Jenderal. Sehingga tanggung jawab yang dibebankan kepada Gubernur Jenderal sangat besar. Pada saat itu pula, Indonesia tidak terlihat seperti negara namun sebagai bagian dari Kerajaan Belanda, dimana posisinya berada setingkat dengan provinsi. Selain hal tersebut pada jaman Hindia-Belanda, Indonesia hanya dikenal dengan 2 wilayah saja diantaranya bagian Jawa dan Madura dan selanjutnya bagian daerah di luar Jawa dan Madura.

Pemerintah Hindia-Belanda pada tahun 1903-1922 memberlakukan Besturk Hervorningsweet, regenschaff dan staat gementan untuk daerah bagian Jawa dan Madura, sedangkan untuk daerah yang 
berada di Luar jawa dan Madura memberlakukan Groeps Gamenschaffen dan Staat Gementen. Besturk Hervorningsweet adalah suatu bentuk kepemerintahan daerah yang mandiri dalam mengurus rumah tangganya setingkat dengan provinsi. Di lain sisi juga dibentuklah Dewan Perwakilan Rakyat (DPR) sebagai perpanjangan tangan dari aspirasi masyarakat di lingkup daerah disebut sebagai swapraja (selevel dengan kabupaten) dan di desadesa.

Namun kehadiran Jepang yang menjajah Indonesia sejak tahun 19421945 atau sekitar 3,5 tahun mengubah semua sistem yang dibentuk oleh pemerintah Hindia-Belanda seakan tidak berguna. Selain itu perubahan perkembangan dalam tatanan pemerintahpun tidak terkecualikan. Hanya saja saat itu, Jepang masih menyisahkan dan melanjutkan asas yang diterapkan pada saat pemerintahan Belanda yaitu asas Dekonsentrasi. Asas yang digunakan masih Dekonsentrasi, namun Jepang mengubah bahasanya menjadi bahasa Jepang pada penamaan daerah dan pejabat; jabatan-jabatan/posisi-posisi yang ditempati oleh Belanda digantikan oleh pihak-pihak dari Jepang. Selain hal tersebut Jepang juga menghapus afdeling beserta asisten karasidenan dan 2 (dua) isitilah wilayah Jawa dan Wilayah Luar Jawa yang dibentuk oleh Belanda pada jamannya.

\subsection{Administrasi pemerintah daerah pada masa penjajahan Jepang} Jepang menduduki Indonesia dengan kekuatan fasisme. Semua urusan yang dilakukan oleh pemerintahan Jepang menggunakan kekuatan militer sebagai bentuk sistem komando kemiliteran. Bahkan Jepang membagi Indonesia dalam tiga daerah, ialah daerah Pulau Jawa, Pulau Sumatera, serta daerah luar Jawa dan Sumatera. Jepang juga membentuk basis atau pangkalan dari dunia kemiliteran, dimana Angkatan Darat (AD) berbasis di Pulau Jawa dan Pulau 
Sumatera atau lebih tepatnya berlokasi di Jakarta dan Bukittinggi. Sedangkan Angkatan Laut (AL) berada di Sumatera dan di Luar Jawa dengan basis terbesar berada di Makassar.

Jepang telah melakukan perubahan-perubahan yang signifikan khususnya pada sistem pemerintahan daerah di Indonesia. Namun pada masa-masa akhir penjajahannya, Jepang kembali menjalankan asas desentralisasi. Sebagai wujud adanya asas desentralisasi, Jepang membentuk dewa di Pulau Jawa bernama Tyoo-Sangiin, dewan karesidenan bernama Syuu-Sangikai, dan dewan kota praja bernama Tokubetsu-Sisangikaai. Namun pembentukan dewan-dewan ini kurang berfungsi dengan baik karena pemilihan anggota dilakukan dengan pemilihan secara bertingkat.

Pada Perang Asia Pasifik, kekalahan Jepang tidak dapat terhindari. Hal tersebut membawa angin segar bagi masyarakat Indonesia. Momentum tersebut dimanfaatkan oleh mayarakat Indonesia untuk melepaskan dirinya dari penjajahan Jepang yang kemudian Indonesia mendapat kemerdekaannya agar menjadi bangsa dan negara yang berdaulat dalam menjalankan roda pemerintahannya. Selain itu, Indonesia juga mengesahkan UUD 1945 sebagai dasar hukum yang tertulis yang digunakan hingga saat ini.

\subsection{Administrasi pemerintah daerah pada masa setelah Kemerdekaan}




$\begin{array}{cc}\text { Administrasi } & \text { Administrasi } \\ \text { pemerintah } & \text { pemerintah } \\ \text { daerah masa } & \text { daerah masa } \\ \text { berlakunya UUD } & \text { berlakunya UUD } \\ 1945 & \text { Sementara } 1950\end{array}$

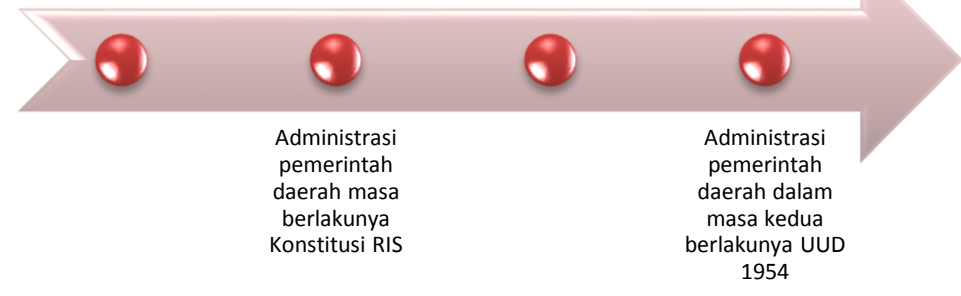

Gambar 1.2.

Administrasu Pemerintah Daerah Pada Masa Setelah

Kemerdekaan

\subsubsection{Administrasi pemerintah daerah masa berlakunya UUD 1945}

Tokoh-tokoh bangsa mulai menyiapkan kelengkapan administrasinya agar Indonesia dapat diakui oleh negara lain sebagai negara yang merdeka maka pada tanggal 28 Mei 1945 Dr. Radjiman widyadiningrat pada saat itu menjadi ketua dari Badan Penyelidik Usaha-usaha Persiapan Kemerdekaan Indonesia (BPUPKI) dan telah mengadakan sidang pertamanya pada tanggal 29 Mei 1945. Pada tanggal 7 agustus 1945 BPUPKI dibubarkan dan diganti dengan pembentukan Panitia Persiapan Kemerdekaan Indonesia (PPKI). Bulan Agustus adalah bulan dimana rakyat Indonesia bersuka cita atas pernyataan kemerdekaanya, lebih tepatnya kemerdekaan tersebut jatuh pada tanggal 17 Agustus 1945 dan hingga sekarang kita merayakannya. Sehari kemudian dasar negara yaitu Pancasila dan Undang-Undang tertinggi terbentuk dengan menunjuk sepasang pemimpin pertama di Indonesia yang ditunjuk sebagai presiden beserta wakilnya ia adalah Ir. Soekarno dan Drs. Mohammad Hatta. 
Sidang ketiga PPKI diselenggarakan pada tanggal 22 Agustus 1945 yang membahas dan menghasilkan sebuah keputusan untuk membentuk Komite Nasional Indonesia Pusat dimana wakil-wakil daerah yang ada di Jakarta adalah anggota dari komite tersebut. Sistem pemerintahan daerah di Indonesia telah menjalankan asas desentralisasi dan dekonsentrasi berdasarkan pasal 18 UndangUndang Dasar Tahun 1945. Pasal ini menjelaskan mengenai daerahdaerah Indonesia terbagi dalam daerah provinsi yang selanjutnya dibagi kembali menjadi wilayah (daerah) yang lebih kecil yang sekarang disebut dengan isitilah Kabupaten atau Kota.

Undang-Undang Dasar Tahun 1945, pada pasal 18 menjelaskan daerah-daerah administratif di wilayah Indonesia. Hasil dari adanya dasar permusyawaratan adalah daerah administratif memiliki suatu abdab perwakilan daerah. Pasal tersebut juga mengakui bahwa keberadaan desa atau setingkat dengan desa memiliki sifat yang istimewa di daerah. Selain hal tersebut, dalam pasal tersebut dalam penjelasannya mengamanatkan pelaksanaan asas desentralisasi dan dekonsentrasi. Desentralisasi sendiri adalah adanya pembentukan wilayah-wilayah yang kewenangannya diberikan pada daerah otonom sedangkan untuk dekonsentrasi pembentukan wilayah yang berada di sekitar wilayah administrasinya.

Pada awal kemerdekaan, setiap daerah provinsi di Indonesia dipimpin oleh seorang residen. Selanjutnya residen dan gubernur dibantu oleh para Komite Nasional Daerah dalam menjalankan tugas kepemerintahannya, dimana pada saat itu Komite Nasional Daerah ditunjuk sebagai dewan rakyat. Tidak lama kemudian, Komite Nasional Pusat diberikan kekuasaan atau kewenangan oleh wakil presiden untuk berkuasa di legislatif di tanggal 16 Oktober 1945 yang termuat dalam maklumat Nomor 10. Dalam rangka mendukung adanya kekuasaan legislatif di daerah, maka disyahkannya Undang- 
Undang Nomor 1 Tahun 1945 yang menjelaskan bahwa Komite Nasional Daerah bertindak sebagai Dewan Perwakilan Rakyat Daerah (DPRD). Selain kondisi tersebut yang perlu diketahui adalah Indonesia mempunyai 8 provinsi yang kemudian provinsi tersebut dikepalai oleh seorang Gubernur. Kedelapan provinsi tersebut diantaranya sebagai berikut: Sunda Kecil, Sumatera, Jawa Barat, Jawa Timur, Jawa tengah, Borneo, Maluku dan Sulawesi.

Selanjutnya, pada tanggal 10 Juli 1948 pemerintah Indonesia menetapkan Undang-Undang Nomor 22 Tahun 1948 sebagai pendukung mengenai pokok-pokok pemerintahan Daerah. Namun Undang-undang yang mendukung Pasal 18 UUD 1945 tersebut terdapat kekurangan, dimana kekurangan tersebut mengatur pemerintah daerah otonom namun tidak disertai dengan administrasi pemerintah daerahnya.

Tiga tingkatan tersusun dalam sistem negara Indonesia untuk mengatur dan mengurus urusan rumah tangganya, dimana tiga tingkatan tersebut adalah seorang gubernur memimpin wilayah provinsi, Bupati memimpin wilayah Kabupaten (kota Besar) serta desa (kota kecil) yang berhak sehingga mempunyai otonom sendiri. Sedangkan daerah yang tidak memiliki Dewan Perwakilan Rakyat meskipun bentuk daerah karasidenan bukanlah termasuk daerah yang otonom. Hal tersebut dijelaskan dalam Undang-Undang Nomor 22 Tahun 1948.

Selain itu isi dari Undang-Undang nomor 22 Tahun 1948 menyatakan bahwa susunan kepemerintahan terbagi atas Kepala daerah yang mempunyai dua tupoksi yaitu sebagai (1) pengawas kegiatan DPRD, (2) memutuskan bahwa Dewan Pemerintah Harian bertanggung jawab sebagai pemimpin daerah sekaligus menjadi perwakilan dari pemerintah pusat. Susunan pemerintahan yang kedua adalah Dewan 
Perwakilan Rakyat Daerah yang mempunyai wewenang dalam membuat peraturan daerah dan selanjutnya adalah dewan Pemerintah Daerah.

Namun dalam pengimplementasian Undang-Undang Nomor 22 Tahun 1948 terdapat kelemahan yaitu tidak cocok atau tidak maksimalnya penerapannya dikarenakan kondisi dan situasi Indonesia yang masih tidak dapat keluar dari bayang-bayang sistem pendudukan penjajahan Belanda. Undang-undang tersebut hanya mengatur asas Desentralisasi, dimana asas tersebut mempunyai dua jenis pemerintahan daerah yaitu Pemerintahan daerah berdasarkan hak otonom dan Pemerintahan Daerah berdasarkan tugas perbantuan (madebewind). Kedua jenis tersebut memiliki perbedaan yakni proses penyerahan penuh dimana semua pekerjaan atau kegiatan di daerah diselenggarakan dan diberikan kuasanya kepada daerah itu sendiri (otonom). Sedangkan jenis yang kedua adalah proses penyerahan tidak penuh dimana prinsip-prinsip dari dasar daerah masih menjadi kewenangan dari Pemerintah Pusat dan daerah hanya mengatur tata cara menjalankannya saja. Oleh karena Undang-undang tersebut masih perlu penyempurnaan dalam penerapannya.

Disamping apa yang sudah dijabarkan sebelumnya, keinginan yang kuat Belanda untuk menjajah kembali Indonesia menjadikan kesempatan Belanda memegang pemerintahan untuk kedua kalinya yang menyebabkan pembagian dua kepemerintahan yang besar yaitu (1) Pemerintah republik Indonesia yang berdasarkan kemerdekaan pada tanggal 17 Agustus 1945 yang tidak dapat diganggu gugat baik dari pihak Belanda maupun pihak dunia atau negara luar dan (2) kepemerintahan yang didirikan oleh Pemerintah Belanda. 


\subsubsection{Administrasi pemerintah daerah masa berlakunya Konstitusi RIS}

Republik Indonesia Serikat (RIS) adalah hasil keterpaksaan sebuah kesepakatan yang terjadi antara pihak Indonesia dengan upaya kependudukan Belanda yang terjadi pada saat itu dengan membentuk satu negara di tahun 1946 yaitu Negara Indonesia Timur, 1 (satu) negara di tahun 1947 yaitu Negara Sumatera Timur dan 4 (empat) negara di tahun 1948 yakni Negara Sumatera Selatan, Negara Pasundan, Negara Jawa Timur, dan Negara Madura. Sedangkan untuk wilayah atau daerah atau negara lainnya akan terkumpul kedalam golongan Bijeenkomst voor Federal Overleg (BFO) atau disebut dengan Pertemuan Untuk Permusyawaratan Federal, sebagai bagian dari aliran federalisme Belanda. Hal tersebut dilakukan untuk menguatkan posisi republik Indonesia Serikat.

Konstitusi Republik Indonesia Serikat (RIS) adalah sistem untuk mengatur ketentuan-ketentuan mengenai wewenang yang diberikan kepada pemerintah daerah saat itu di masa negara Republik Indonesia Serikat (RIS). Pasal 51 ayat 1 dalam konstitusi ini menjelaskan bahwa setiap urusan pemerintah daerah menjadi wewenang dari negara atau daerah itu sendiri sedangkan negaranegara bagian sebagai pengatur tentang pemerintahan daerahnya dalam suatu UUD negara bagian. Maka dapat diartikan bahwa dengan adanya Konstitusi republik Indonesia Serikat ini menjelaskan sistem pada pembagian urusan pada kewenangan negara federal dan urusan pada kewenangan negara yang pada umumnya menjadi kewewenangan negara federal.

Aturan dan ketentuan tentang daerah-daerah swapraja juga menjadi wewenang negara bagian sesuai pasal 64 dan pasal 65 Konstitusi Republik Indonesia Serikat yang sering disingkat dengan RIS, yakni 
terdapat semacam kontrak sebagai pengatur hubungan negaranegara bagian dengan daerah-daerah swapraja. Kontrak tersebut tertuang dalam Pasal 18 UUD 1945 dan Undang-undang Nomor 22 Tahun 1948 yang menjelaskan bahwa pokok-pokok Pemerintah Daerah hanya diterapkan atau berlaku negara bagian Republik Indonesia saja. Selain itu Daerah swapraja tidak dapat dihapuskan oleh negara bagian kecuali oleh Undang-Undang Federal yang menyatukan. Pada saat itu Indonesia tidak pernah menetapkan Undang-undang apapun sampai negara Kesatuan Republik Indonesia terbentuk kembali selain Negara Indonesia Timur yang menetapkan Undang-Undang Negara Indonesia Timur Nomor 44 tahun 1954 untuk mengatur pemerintahan daerahnya sendiri.

Oleh karena itu, susunan pada sistem aturan pemerintah daerah suatu negara berbeda dengan negara bagian lainnya. Meskipun wewenang diberikan kepada negara bagian itu sendiri. Pada saat itu Pemerintah Republik Indonesia Serikat (RIS) menetapkan Peraturan Pemerintah Republik Indonesia Serikat mengenai pembagian wilayah negara Indonesia menjadi 10 daerah provinsi yang bersifat administratif. Penjelasan tersebut dapat ditinjau dalam Peraturan Pemerintah Republik Indonesia Serikat nomor 21 Tahun 1950 dan lembaran Negara Sumatera Utara, Sumatera Tengah, Sumatera Selatan, Jawa Barat, Jawa Tengah, Jawa Timur, Sunda Kecil, Kalimantan, Sulawesi, dan Maluku. Hal tersebut bertujuan sebagai titik awal dibentuknya daerah otonom di Indonesia. Namun, dibentuknya daerah otonom jelas bertentangan dengan Konstitusi Republik Indonesia Serikat (RIS) yakni kewenangan mengatur pemerintah daerah menjadi bagian dari kewenangan negara bagian. Negara Republik Indonesia Serikat (RIS) tidak bertahan lama, hal tersebut dikarenakan terdapat banyak pertentangan/perdebatan di berbagai daerah. Hal tersebut dilakukan melalui pergerakan- 
pergerakan perjuangan yang menginginkan kembalinya negara ke bentuk unitaris (kesatuan). Pada 19 Mei 1950 Negara Republik Indonesia Serikat hanya terbagi atas tiga negara bagian yaitu Negara Sumatera Timur, Negara Republik Indonesia, Negara Indonesia Timur. Sedangkan, pada negara-negara bagian sebelumnya telah berubah menjadi satuan-satuan kenegaraan yang tegak sendirisendiri (mandiri). Pada akhirnya, daerah-daerah ini bergabung dengan Negara Republik Indonesia yang disebut kemudian dengan Daerah Pulihan. Di daerah ini, telah diberlakukan kembali UndangUndang Nomor 22 Tahun 1948 berdasarkan Peraturan Pemerintah sebagai pengganti Undang-Undang Nomor 1 Tahun 1950 tentang Peraturan Daerah Pulihan, yang mulai berlaku sejak tanggal 13 Maret 1950. Selanjutnya, juga dikeluarkan Undang-Undang Nomor 8 Tahun 1950 yang disyahkan di Yogyakarta yakni mengatur penghapusan peraturan dan undang-undang di daerah-daerah bagian dan daerahdaerah bukan bagian, kecuali tidak bertentangan/berlawanan dengan Peraturan-Peraturan dan Undang-Undang Republik Indonesia.

Selanjutnya, setelah penggabungan menjelang terbentuknya kembali Negara Kesatuan oleh Pemerintah Republik Indonesia Yogyakarta berdasarkan Undang-Undang Nomor 22 Tahun 1948 dibentuklah provinsi-provinsi otonom yang meliputi Sumatera Selatan, Sumatera Tengah, Sumatera Timur, Jawa Barat, DI Yogyakarta, Jawa Tengah, Jawa Timur. Selain dari provinsi-provinsi tersebut, pada saat Negara Indonesia masih bikenal dengan Republik Indonesia Serikat satu provinsi terbentuk daerah otonom yang berjumlah delapan daerah yaitu Kota Jakarta Raya.

\subsubsection{Administrasi pemerintah daerah masa berlakunya UUD} Sementara 1950 
Indonesia pada akhirnya telah kembali menjadi Negara Kesatuan pada tanggal 19 Mei 1950 melalui Piagam Persetujuan. Secara umum, pemerintahan daerah telah diselenggarakan dan berpedoman pada Undang-Undang Sementara 1950 yang memuat tentang daerah di Indonesia terbagi atas daerah besar dan daerah kecil. Setiap daerah diberikan hak otonom untuk melakukan pengaturan dan pengurusan rumah tangga daerahnya sendiri. Sedangkan, bentuk susunan pemerintahannya telah ditetapkan dalam Undang-Undang. Daerah swapraja kebetradaannya masih diakui, tetapi hal tersebut dapat dihapuskan atau diperkecil jika undang-undang menghendakinya. Urusan daerah swapraja telah menjadi urusan dan kewenangan dari pemerintah pusat. Undang-Undang Dasar Sementara Tahun 1950 digunakan sebagai pedoman/acuan hingga terbitnya UndangUndang Nomor 1 Tahun 1957.

Undang-Undang Nomor 1 Tahun 1957 mengenai Pokok-Pokok Pemerintah Daerah disahkan pada tanggal 17 Januari 1957. UndangUndang ini telah dibuat sebagai cerminan dengan adanya pasal 133 UUD Sementara 1950 yang mengatur pembentukan peraturan dan undang-undang yang akan menggantikan UUD Sementara Tahun 1950 sebagai pedoman pengaturan pemerintah daerah di Indonesia. Peraturan ini diberlakukan di seluruh Negara Kesatuan Republik Indonesia (NKRI) dan mengatur terselenggaranya asas-asas desentralisasi dan asas-asas tugas pembantuan sesuai yang dimaksudkan dalam pasal 131 UUD Sementara 1950. Pada fase ini otonom riil sudah diberikan kepada daerah-daerah di Indonesia yang waktu itu dikenal dengan istilah Daerah Swatranta dengan kepemerintahan Daerah Swatranta, daerah Swapraja dengan kepemerintahan Daerah Istimewa dan Kotapraja dengan kepemerintahan Daerah Kota. Namun, kelemahannya undang- 
undang ini tidak mengatur asas dekonsentrasi dan pemerintahan pamong praja.

Pembagian pada wilayah Republik Indonesia terbagi dalam daerah besar dan daerah kecil, yang berhak mengurus rumah tangganya sendiri. Adapun tingkatan daerah meliputi Daerah Tingkat ke I (didalamnya termasuk Kotaparaja Jakarta Raya), Daerah Tingkat ke II (didalamnya termasuk Kotapraja), dan Daerah Tingkat ke III. Sama halnya dengan daerah Swaparaja dibagi atas daerah tingkat ke I, daerah tingkat ke II, dan daerah tingkat ke III. Tingkatan yang sama juga diberlakukan untuk daerah Swatantra (tapi hanya sampai daerah swatantra tingkat ke II).

Undang-Undang Nomor 1 Tahun 1957 menjelaskan bahwa bentuk dan susunan pemerintahan daerah terdiri dari Kepala Daerah, Dewan Perwakilan Rakyat Daerah, dan Dewan Pemerintah Daerah. Anggota Dewan Pemerintah Daerah dipilih dari Anggota Dewan Perwakilan Rakyat Daerah atas dasar perwakilan berimbang. Berbeda halnya dengan ketua dan wakil ketua DPRD tidak boleh menjadi anggota Dewan Pemerintah Daerah. Sedangkan Kepala Daerah ialah sebagai ketua serta anggota Dewan Pemerintah Daerah. DPRD dan Dewan Pemerintah Daerah sebagai alat kelengkapan daerah yang mempunyai tugas dan kewajiban dalam mengurus semua urusan rumah tangganya sendiri dan dapat pula diberi tugas untuk membantu menjalankan/menyelenggarakan peraturan-peraturan oleh instansi-instansi yang lebih tinggi.

DPRD menjadi bagian dari lembaga yang mempunyai kewenangan di bidang legislatif yakni memiliki fungsi sebagai pembuat peraturan daerah atau kebijakan daerah. Berbeda halnya dengan Dewan Pemerintah Daerah, sebagai badan yang mempunyai sifat kolegial 
dengan Kepala Daerah. Dewan Pemerintah Daerah melaksanakan keputusan-keputusan DPRD, dan Dewan Pemerintah Daerah juga dapat diserahi tugas untuk menetapkan pelaksanaan dari kebijakan daearh. Pemilihan Kepala Daerah dilakukan melalui pilihan langsung oleh masyarakat, dan ketentuan mengenai pengangkatan serta pemberhentiannya diatur melalui undang-undang yang berlaku.

Berbeda halnya dengan Daerah Istimewa, Kepala Daerah dipilih dan diangkat dari calon yang diajukan DPRD. Kepala Daerah biasanya dipilih dan diangkat dari keturunan keluarga yang berkuasa di daerah yang bersangkutan. Beberapa kriteria pemilihannya yaitu harus memperhatikan syarat-syarat kecakapan, kejujuran, kesetiaan, serta adat istiadat dalam daerah yang bersangkutan. Namun, dalam implmentasi Undang-Undang Nomor 1 Tahun 1957 perlu memperhatikan satu hal, yakni pada peraturan tersebut tidak mengatur secara jelas mengenai daerah yang mempunyai sifat administratif (pemerintahan umum). Sama dengan ketika UndangUndang Nomor 22 Tahun 1948 berlaku, termuat kedudukan mengenai pemerintahan di daerah administratif yang diatur dengan tidak begitu jelas. Padahal, dalam Undang-Undang Nomor 1 Tahun 1957 memuat pelaksanaan asas otonomi riil yang seluas-luasnya. Oleh karena itu, dalam pelaksanaan berbagai mekanisme pemerintahan umum di daerah-daerah khususnya di daerah Swatantra maka telah dikeluarkan dan ditetapkan Undang-Undang Nomor 6 Tahun 1959 mengeanai Penyerahan Pemerintahan Umum. Dalam UU tersebut telah diatur penyerahan semua tugas pemerintah pusat dalam bidang pemerintah umum yang ada di daerah, yang nantinya untuk dijadikan urusan rumah tangganya sendiri. Hal tersebut terdiri beberapa bagian diantaranya, bidang pemerintahan umum, pembantuan pegawai, dan tata cara penyerahan keuangan kepada pemerintah daerah. 
Namun dalam Undang-Undang Nomor 6 Tahun 1959 mempunyai kekurangan dimana aturan untuk pembagian kewenangan antara pihak pemerinath daerah dan pusat tidak jelas seperti pembagian urusan ketertiban dan keamanan umum yang ada di daerah, serta pengawasan pada penyelenggaraan pemerintah daerah. Sehingga undang-undang tersebut dihapus karena Secara keseluruhan kewenangan diatas menjadi bagian dari pemerintah pusat. Sedangkan untuk nasip pekerja yang bekerja didaerah administratif tersebut dipindahkan untuk diperbantukan ke daeran otonom (Swatranta).

\subsubsection{Administrasi pemerintah daerah dalam masa kedua berlakunya UUD 1945}

Sejak diberlakukannya UUD 1945 pada masa yang kedua, telah banyak dilakukan perubahan sebagai penyempurnaan untuk kemajuan pemerintahan daerah di Indonesia. Fase yang demikian berawal dengan kembalinya negara Indonesia ke konstitusi UUD 1945, yaitu dengan dikeluarkannya Dekrit Presiden 5 Juli 1959. Sedangkan, pada undang-undang yang mengatur mengenai mekanisme pemerintahan daerah di Indonesia saat itu yaitu UndangUndang Nomor 5 Tahun 1974 mengenai Pokok-Pokok Pemerintahan Daerah.

Undang-Undang Nomor 5 Tahun 1974 yang mengatur mengenai asas-asas dalam pemerintahan daerah diantaranya asas desentralisasi, asas dekonsentrasi, dan tugas pembantuan. UndangUndang ini telah menggantikan Undang-Undang Nomor 18 Tahun 1965 dimana sebelumnya telah dibuat untuk mengatur pemerintahan daerah di Indonesia. Pemerintahan daerah dalam Undang-Undang ini terbagi dalam dua jenis, yakni pemerintahan 
daerah yang bersifat otonom dan pemerintahan daerah yang bersifat administratif.

Pemerintahan daerah otonom telah lahir sebagai perwujudan/penyelenggaraan dari asas desentralisasi. Asas desentralisasi yakni asas penyerahan urusan pemerintah pusat (daerah otonom tingkat atasnya) yang diberikan kepada daerah otonom. Daerah otonom tersebut yaitu daerah tingkat II (Kabupaten/ Kota). Sedangkan, daerah otonom tingkat atasnya adalah daerah tingkat I (provinsi). Perangkat daerah di pemerintahan daerah tingkat II dikepalai oleh seorang kepala daerah (Bupati/Walikota) dan Dewan Perwakilan Rakyat Daerah (DPRD). Kepala daerah tingkat II dilakukan pencalonan dan pemilihan dari Dewan Perwakilan Rakyat Daerah. Selanjutnya, pemilihan tersebut akan dipertimbangkan oleh pimpinan DPRD/pimpinan fraksi dengan Gubernur. Sedangkan untuk pemilihan kepala daerah tingkat I (gubernur), dilakukan pencalonan dan pemilihan dari DPRD Provinsi dan akan dimusyawarahkan dan disepakati bersama antara pimpinan DPRD/pimpinan fraksi dengan menteri dalam negeri.

Dalam Undang-Undang Nomor 5 Tahun 1974, juga dikenal jabatan/posisi pada wakil kepala daerah tingkat I dan tingkat II. Wakil kepala daerah tingkat I menjadi bagian dari pegawai negeri yang memenuhi persyaratan-persyaratan sesuai ketentuan yang berlaku dan diangkat oleh Presiden. Sedangkan, untuk wakil kepala daerah tingkat II menjadi bagian dari pegawai negeri yang memenuhi persyaratan-persyaratan sesuai ketentuan yang berlaku dan dilakukan pengangkatan oleh menteri dalam negeri atas nama Presiden. Syarat-syarat untuk memenuhi pengangkatan sebagai wakil kepala daerah sama halnya dengan syarat-syarat menjadi kepala daerah. 
Undang-Undang Nomor 5 Tahun 1974 juga mengamanatkan mengenai bentuk susunan perangkat pemerintah kepala daerah yang secara garis besar dapat dipetakan/digambarkan sebagai berikut, jabatan Gubernur sebagai kepala daerah tingkat I (provinsi), jabatan Bupati sebagai kepala daerah tingkat II (Kabupaten), jabatan Walikotamadya untuk daerah kota madya yang notabenenya setingkat daerah tingkat II, walikota untuk daerah kota administratif juga setingkat daerah tingkat II, serta jabatan camat untuk kepala daerah kecamatan.

Dalam perangkat pemerintah daerah selain kepala daerah, juga terdapat Dewan Perwakilan Rakyat Daerah (DPRD). DPRD terletak ditingkat Daerah I dan di tingkat Daerah II. DPRD mempunyai tugas di bidang legislatif (pembuat kebijakan/peraturan), sedangkan Kepala Daerah memiliki kewenangan eksekutif (pelaksana kebijakan/peraturan). Tupoksi dari DPRD diantaranya pemberian persetujuan kepada kepala daerah dalam hal membuat peraturan daerah untuk kepentingan daerah; bersama-sama dengan kepala daerah melakukan penyusunan Anggaran Pendapatan dan Belanja Daerah atau yang sering dikenal dengan APBD; serta melakukan pengawasan pada jalannya pemerintahan daerah.

Amanat yang termuat dalam Undang-Undang Nomor 5 Tahun 1974, selain mengenal daerah otonom juga mengenal daerah yang bersifat administratif. Daerah administratif lahir sebagai perwujudan/penyelenggaraan atas asas dekonsentrasi yang diberikan pemerintah pusat kepada pemerintah daerah. Wilayah daerah administratif merupakan bagian lingkungan kerja dari perangkat pemerintah pusat yang turut menyelenggarakan pelaksanaan pada tugas pemerintahan umum di daerah. Wilayah daerah administratif menjadi wilayah provinsi yang terbagi atas kabupaten dan kota serta wilayah kabupaten dan kota yang terbagi- 
bagi lagi menjadi wilayah kecamatan. Pada wilayah kabupaten juga dapat dibentuk Kota Administratif apabila hal tersebut diperlukan dan disesuaikan dengan perkembangan pada kondisi masing-masing daerah. Dengan demikian, dapat disimpulkan bahwa perihal sistem kepemerintahan daerah dalam Undang-Undang Nomor 5 Tahun 1974 telah dijelaskan secara terinci dan tersistem dengan sempurna yaitu aturan yang telah mengatur dari segi daerah atau wilayah, penggunaan asas atau prinsip, tugas dan tanggung jawab setiap perangkat daerah dan tugas yang diberikan oleh pusat kepada daeorah otonom dan daerah administratif.

Seiring berjalannya waktu, perjalanan bangsa Indonesia dapat digambarkan bahwa Indonesia menetapkan peraturan mengenai aturan kepemerintahan desa yang dapat dipertimbangkan untuk membuat peraturan daerah pada saat itu. Perihal tersebut dapat dijelaskan dengan adanya Undang-Undang nomor 5 Tahun 1979. Namun perkembangan Indonesia yang begitu dinamis UndangUndang tersebut tidak dapat diterapkan hingga sekarang dengan tujuan penyempurnaan sistem pemerintah daerah. Dengan demikian pada tahun 1999, undang-undang tersebut dihapus dan digantikan dengan undang-undang nomor 22 Tahun 1999 menegnai Pemerintahan daerah.

Undang-Undang tersebut telah ditetapkan pada saat memeriahkan reformasi pemerintah yang sempat memanas di Indonesia. Selanjutnya, Undang-Undang Nomor 22 Tahun 1999 direvisi menjadi Undang-Undang Nomor 32 Tahun 2004 yang dipakai dalam pengaturan mekanisme pemerintahan daerah di Indonesia. Berdasarkan periodisasi yang telah kita lalui dimulai dari zaman Hindia-Belanda hingga berlakunya Undang-Undang Nomor 5 Tahun 1974 diatas dapat disimpulkan bahwa perkembangan pemerintahan daerah selalu mengalami perubahan-perubahan yang dinamis untuk penyempurnaan sistem pemerintahan daerah di Indonesia. Selain 
itu, pada setiap periode yang telah ditempuh oleh Indonesia, akan dapat dibandingkan pemerintahan daerah dari waktu ke waktu. Sehingga, akan dapat terlihat dan dipelajari masing-masing kelebihan dan kelemahan pada masing-masing periodisasi.

\section{Quiz}

Berdasarkan penjelasan pada materi perkembangan administrasi pemerintah daerah di Indonesia, maka untuk mengetahui tingkat pemahaman mahasiswa berikut merupakan serangkaian pertanyaan yang harus dijawab dan dipaparkan mahasiswa guna mencapai tujuan yang diinginkan sebagai berikut:

1. Jelaskan perkembangan administrasi daerah di Indonesia!

2. Jelaskan perbedaan peerkembangan administrasi daerah di Indonesia pada saat penjajahan dan kemerdekaan!

3. Jelaskan dampak positif dan negatif dalam setiap perkembangan administrasi daerah di Indonesia!

\section{E. Simpulan}

Sistem administrasi pemerintah daera di Indonesia mengalami perkembangan sebanyak tiga kali yaitu administrasi pemerintah daerah pada masa penjajahan Belanda, administrasi pemerintahan daerah pada masa penjajahan jepang dan administrasi pemerintah daerah pada masa setelah kemerdekaan. Pada tahun 1903-1922, Indonesia menganut paham sentralistik dimana pemahaman tersebut segala keputusan dan tanggung jawab penuh berada di tangan pimpinan. Berbeda pada tahun 1942-1945, administrasi pemerintah daerah yang diberlakukan pada saat penjajahan Belanda tidak digunakan lagi oleh Jepang. Jepang memberlakukan kekuatan militer sebagai kekuatan terbesar dalam tatanan administrasi pemerintah daerah. Namun pada akhir penjajahan Jepang, mereka kembali memberlakukan sistem sentalistik dengan asas desentralisasi. 
Kekalahan Jepang membawa harapan besar bagi bangsa Indonesia untuk memproklamasikan kemerdekaanya. Sehingga harapan tersebut diwujudkan dengan adanya perkembangan administrasi pemerintah daerah di masa kemerdekaan. Sejarah perkembangan administrasi pemerintah daerah di masa tersebut menjelaskan bahwa terjadi pergantian sistem administrasi pemerintah daerah sebanyak empat kali yaitu administrasi pemerintah daerah pada masa berlakunya Undang-Undang Dasar 1945, perkembangan administrasi pemerintah daerah pada masa diberlakukannya konstitusi Republik Indonesia Serikat (RIS), perkembangan administrasi pemerintah darah pada masa berlakunya Undang-Undang Sementara 1950 dan perkembangan administrasi pemerintah daerah pada masa berlakunya UndangUndang Dasar 1945.

\section{F. Daftar Pustaka}

Abdurrahman. (1987). Beberapa Pemikiran Tentang Otonomi Daerah. Jakarta: Media Sarana Press.

Andriansyah. (2015). Administrasi pemerintahan daerah dalam analisa. Jakarta: FISIP Universitas Prof. Dr. Moestopo Beragama.

Arenawati. (2014). Administrasi pemerintahan daerah: Sejarah konsep dan pelaksanaan di Indonesia. Yogyakarta: Graha IImu.

Huda, N. (2005). Otonomi daerah filosofi, sejarah perkembangannya, dan problematikanya. Yogyakarta: Pustaka Pelajar.

Isjwara, F. (1974). Pengantar IImu Politik . Bandung: Bina Cipta. 


\section{BAB II}

\section{PENGANTAR DESENTRALISASI}

\section{A. Deskripsi Singkat}

Amandemen Undang-Undang Dasar 1945 Pasal 18 mengemukakan bahwa Pemerintah Daerah Kabupaten, Daerah Kota, dan Daerah Provinsi mengatur urusan pemerintahannya sendiri berdasarkan asas otonomi dan tugas pembantuan. Asas penyelenggaraan pemerintahan daerah yang pernah berlaku di Indonesia yang tersurat adalah desentralisasi, dekonsentrasi dan 
tugas pembantuan. Sedangkan yang tersirat adalah Vrijbestuur (Tampung Tantra).

Desentralisasi dapat digolongkan menjadi dua jenis yaitu desentralisasi kenegaraan dan desentralisasi jabatan. Desentralisasi kenegaraan digolongkan menjadi dua bagian yaitu desentralisasi teritorial dan desentralisasi fungsional, sedangkan dekonsentrasi dibedakan menjadi dua bagian yaitu dekonsentrasi vertikal dan dekonsentrasi horizontal. Prinsip-prinsip penyelenggaraan pemerintahan yaitu berdasarkan pada asas desentralisasi, dekonsentrasi dan tugas pembantuan.

Otonomi mempunyai suatu benang merah dengan asas desentralisasi. Hal tersebut dikarenakan pemimpin daerah mempunyai kewenangan atau kekuasaan untuk mengatur daerahnya sendiri sehingga dapat memahami apa yang dibutuhkan daerahnya dan apa yang tidak dibutuhkan oleh daerahnya dalam mengurus urusan rumah tangganya. Mahfud MD (2000:66) menjelaskan bahwa sebagai upaya penerapan demokrasi, Pemerintah Indonesia hendaknya memberikan kepercayaan yang dimulai dari membuat, menerapkan kebijakan, merencanakan anggaran, dan lain sebagainya diserahkan kepada pemerintah daerah. Hal tersebutlah yang dinamakan dengan desentralisasi. Oleh karena itu otonom dan desentralisasi mempunyai hubungan erat satu sama lain.

\section{B. Kompetensi Dasar}

Mahasiswa mampu memahami dan mengidentifikasi pengantar desentralisasi di Indonesia.

\section{Indikator}

1. Mahasiswa mampu mengetahui dan mengidentifikasi teori utama desentralisasi. 
2. Mahasiswa mampu mengetahui dan mengidentifikasi rentang perdebatan teori desentralisasi : Rondinelli vs Slater.

3. Mahasiswa mampu mengetahui dan mengidentifikasi rentang pengertian desentralisasi.

4. Mahasiswa mampu mengetahui dan mengidentifikasi derajat desentralisasi.

\subsection{Teori Utama Desentralisasi}

Desentralisasi menurut pandangan Smith dalam Muluk (2005) saat ini telah menunjukkan sifat umum menyeluruh (universal) yang dapat digunakan oleh berbagai sudut pandang dari segala arah. Oleh karena itu untuk menjelaskan seberapa pentingnya arti dari pemerintah daerah (local government), tentunya diperlukan perhatian terhadap perkembangan teoritik dari berbagai perspektif yang ada dalam memandang pemerintahan daerah. Keberadaan pemerintah daerah merupakan konsekuensi dari desentralisasi mendapat penafsiran dari teori-teri sosial yaitu Teori Demokrasi Liberal, Teori Pilihan Publik dan Teori Marxis, sebagaimana dipaparkan dalam gambar berikut : 


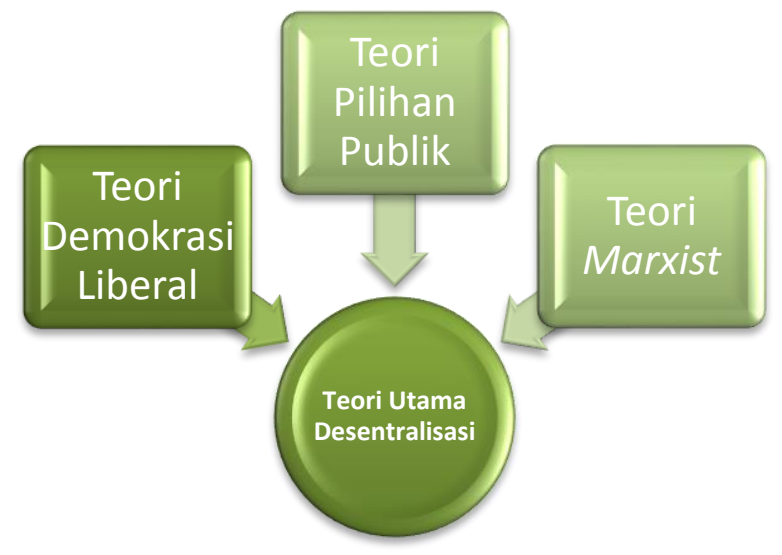

Gambar 2.1.

Teori Utama Desentralisasi

1. Pandangan Teori Demokrasi Liberal.

Perspektif teori demokrasi liberal menyatakan bahwa desentralisasi mendapat dukungan karena mampu mendukung demokrasi pada dua tingkatan. Pertama: memberikan kontribusi positif bagi perkembangan demokrasi nasional, karena local government mampu menjadi sarana bagi pendidikan politik rakyat dan memberi pelatihan bagi kepemimpinan politik, serta mendukung penciptaan stabilitas politik. Dalam pandangan ini Hossein (2000) dalam Muluk (2005) menegaskan bahwa konsep otonomi memiliki makna kebebasan untuk berpendapat dalam mengambil keputusan atas dasar partisipasasi masyarakat yang memiliki status demikian tanpa kontrol langsung oleh pemerintah (pusat). Oleh karena itu, sangat berkaitan erat dengan demokrasi. Kedua: Local government mampu memberikan manfaat bagi masyarakat setempat (locality). Lebih lanjut dikemukakan Hossein (2001) dalam Muluk (2005) bahwa: "Local government dan Local otonomi tidak dicerna sebagai daerah atau pemerintah daerah, tetapi merupakan masyarakat setempat. 
Urusan dan kepentingan yang menjadi perhatian keduanya bersifat lokalitas karena basis patokannya lokalitas tersebut bukan bangsa." Menurut Norton (1997) dalam Muluk (2005) “Makna lokalitas ini juga tercermin dalam berbagai istilah diberbagai Negara yang merujuk pada maksud yang sama, seperti Commune di Prancis, Gemeinde di Jerman, Gemente di Belanda, dan Municipio di Spanyol, yang kemudian menyerupai Municipality di Amerika Serikat." Manfaatnya bagi masyarakat setempat adalah adanya political equality, accountability, dan responsiveness.

Pandangan senada dikemukakan oleh Antaft dan Novack (1998) dalam Muluk (2005) yang mengungkapkan bahwa: "Manfaat dari local government ini dalam beberapa hal yakni: accountability, responsiveness, apportuinity for experimentation, public chois, spread of power, and democratic values". Secara sederhana teori demokrasi liberal adalah teori yang memandang desentralisasi bermanfaat sebagai demokrasi nasional dan bermanfaat bagi masyarakat setempat.

2. Pandangan Teori Pilihan Publik

Penafsiran teori pilihan publik tentang desentralisasi menunjukkan adanya dukungan dari ahli ekonomi dikarenakan para ahli tersebut sepakat bahwa teori pilihan publik dapat memebrikan dampak postif kepada masyarakat yaitu kesejahteraannya. Salah satunya dalam buku Muluk (2005) yang menjelaskan bahwa Stoker mengemukakan teori pilihan publik dalam perspektif ekonomi yang menjelaskan bahwa desentralisasi adalah sarana untuk meningkatkan kesejahteraan individu melalui pilihan publik. Pandangan ini menggambarkan kehidupan masyarakat yang tiap daerah berbeda dalam memilih tempat tinggal yang diiringi dengan kualitas pelayanan dan pajak yang ditawarkan. Namun kembali kepada masayrakat kebanyakan, bahwa masyarakat akan memilih tempat 
tinggal yang dapat memberikan kualitas terbaiknya. Dari perspektif inilah dapat diketahui manfaat dari pemerintah daerah dan perbedaannya dengan layanan swasta yaitu adanya respon publik terhadapa keinginanannya secara personal yang memilih menggunakan dan memanfaatkan kebijakan atau pelayanan publik dengan bentuk barang atau jasa yang berbeda dengan pelayanan pihak swasta yang ditawarkan. Kedua, keunggulan dari pelayanan pemerintah adalah dapat terpenuhinya segala kebutuhan yang dibutuhkan oleh masyarakat seberapapun banyaknta permintaan akan barang-barang publik, dalam artian akan selalu tersedia. Namun, keinginan pasar akan lebih mudah dipahami oleh pihak swasta dibandingkan pihak pemerintah dikarenakan sulitnya mengetahui dan mengidentifikasi diakrenakan suasana politik yang tidak menentu yang mengakibatkan kerumitan untuk memperoleh barang, harga dan lain sebagainya yang dibutuhkan. Oleh karena itu melalui desentralisasi jumlah unit-unit pemerintahan ditingkatkan agar mampu menyelesaikan persoalan tersebut. Derajat spesialisasi fungsi unit pemerintahan juga ditingkatkan sehingga kapasitas pemerintah lebih besar dalam memenuhi permintaan publik. Ketiga, desentralisasi mampu menyediakan penawaran barang-barang publik yang lebih baik dan memuaskan masyarakat. Terdapat banyak persoalan jika penyediaan pelayanan dan barang publik tersentralisasikan. Semakin besar oraganisasinya, maka semakin besar pula kecenderungan untuk memberikan pelayanan. Semaikin monopolistis suatu pemerintah maka semakin kecil insentif dan inovatifnya, berdasarkan teori, yurisdiksi terfragmentasi akan lebih memberikan kepuasan kepada konsumen dari pada kewenangan yang terkonsolidasi. Desentralisasi akan memberikan antar yurisdiksi yang berbeda untuk bersaing dalam memberikan keputusan kepada publik atas penyediaan barang dan lanyanan. 
Secara sederhana teori pilihan publik adalah suatu teori yang memandang desentralisasi sebagai feedback atau daya tanggap publik terhdap prefensi atau alternatif-alternatif individual yang dapat dilakukan, pemenuhan barang-barang publik, penyediaan komoditas publik yang lebih memuaskan. Jadi didalam teori ini masyarakat dapat menentukan pilihannya berdasarkan hal tersebut atau kebijakan yang diberikan pemerintah bermanfaat dan berdampak besar bagi dirinya.

\section{Pandangan Teori Marxist}

Para ahli dalam teori ini beranggapan bahwa desentralisasi mengakibatkan adanya Negara pada tingkat lokal. Pandangan dalam teori ini menyatakan bahwa desentralisasi tidak akan mampu memberikan dampak positif kepada masyarakat salah satunya adalah tidak terciptanya keadaan yang demokratis di tingkat daerah dikarenakan dengan adanya desentralisasi akan menjadi penghambat bagi kebijakan dari segi ekonomi poltik, dan ekologi. Interpretasi Marxist tampaknya masih cenderung memandang Negara sebagai suatu kesatuan dan tidak terpisah-pisah antar wilayah geografisnya.

Ketidak-berpihakan penafsiran Marxist terhadap desentralisasi dikemukakan dalam lima poin penting. Pertama, teori ini beranggapan bahwa desentralisasi atau pembagian wilayah akan memberikan akses bagi kemunculan kaum kapitalis karena adanya akumulasi modal. Kedua, desentralisasi rentan akan politisasi karena dipengaruhi oleh konsumsi kolektif. Konsumsi kolektif bertujuan untuk memberikan pelayanan secara merata dan mementingkan semua elemen dari masyarakat, akan tetapi timbul permasalahan 
baru dalam sistem desentralisasi yaitu adanya sifat konsumsi kelektif setiap daerah. Selanjutnya, suatu demokrasi di negara diperuntukkan bagi kelas pekerja pada umumnya, namun kaum kapitalis mempunyai banyak cara agar hal tersbut tidak dapat terwujud, dikarenakan mereka dianggap tidak pantas untuk mendudukan sistem pemerintahan. Selain itu, dalam mengelola rumah tangganya pemerintah wilayah hanya akan menjadi perpanjangan tangan pemerintah (pusat) untuk menjaga kepentingan monopoly capital. Oleh sebab itu pandangan ini menjelaskan bahwa desentralisasi tidak pernah memebrikan dampak yang positif ataupun dampak yang menguntungkan bagi wilayah pinggiran dalam bidang pembangunan. Kelima, pelaksanaan desentralisasi dan demokrasi lokal mengalami berbagai macam hambatan. Hambatan ini memuat aspek politik, ekonomi, dan ekologis yang dapat menimbulkan kegagalan demokrasi di tingkat lokal. Pada akhirnya sudut pandang dari teori ini akan menjelaskan bahwa segala persoalan dari desentralisasi dapat dipecahkan dengan sentralisasi yang mempunyai tujuan adanya hubungan timbal balik antara kaum kapitalis dan rasa keadilan bagi kaum pinggiran. Oleh karena itu, teori Marxist adalah teori yang lebih cenderung menolak desentralisasi karena menimbulkan kerugiankerugian yang hanya menimbulkan ketakutan bagi masyarakat miskin dimana akan memunculkan pengusaha-pengusaha lokal yang menjadikan kondisi tersebut berada dimana yang kaya semakin jaya dan sebaliknya.

1. Hubungan Antara Pusat dan Daerah dalam Negara Kesatuan Negara yang berbentuk federal adalah negara yang mempunyai ruang gerak yang bebas untuk mengatur kekuasaan yang ada di negaranya. Sehingga bentuk federal dapat dikatakan desentralis yang mempunyai tingkat demokratis yang tinggi. Sedangkan berbeda dengan negara negara yang terbentuk sentralis. Negara yang 
sentralis memberikan ruang gerak yang sempit dalam pemberian kekuasaannya dikarenakan semua kekuasaan bertumpu pada pemerintah pusat sedangkan disisi lain pemerintah daerah diberi hak untuk melaksanakan daerah otonom. Sehingga hal tersebut menjadi ketertarikan sendiri untuk meneliti mengenai bagaimana hubunfan antara pusat dan daerah dalam mengelola negaranya yang kesatuan. (Nasution, dkk; 2007).

Kekokohan pada bentuk suatu kenegaraan adalah adanya negara kesatuan dikarenakan terdapat dua kata kunci yang tidak terpisahkan yaitu persatuan (union) dan kesatuan (unity). Hal tersebut menjadi keunggulan tersendiri jika diukur dengan negara federal atau konfederasi. Hal tersebut pula menjadikan bahwa negara kesatuan tidak terbentuk dari beberapa negara melainkan hanya terbentuk dengan satu negara (Isjwara, 1974). Mengenai pendapat ini, disampaikan juga oleh Husroh (1990) yang menyampaikan bahwa banyaknya negara yang terbentuk bukan berarti negara tersebut adalah negara kesatuan seperti negara federal. Negara kesatuan itu adalah negara yang tunggal tidak adanya negara didalam negara. Terdapatnya satu pemerintahan yaitu pemerintah pusat yang mengatur dan mempunyai kekuasaan ataupun wewenang tertinggi dalam mengurusi segala urusan pemerintahan. Pemerintahan yang tertinggi inilah yang dapat memberikan segala keputusan yang ada dalam negara tersebut. Seperti halnya di negara Indonesia yang kekuasaan tertingginya berada di tangan Presiden.

Menurut Abdurrahman (1987) terdapat dua bentuk negara kesatuan yaitu:

(a) Negara kesatuan dengan sistem sentralisasi.

Negara kesatuan dengan sistem sentralisasi segala sesuatu dalam negara langsung diatur dan diurus oleh pemerintah pusat dan 
daerah-daerah hanya tinggal melaksanakan segala apa yang telah diinstruksikan oleh pemerintah pusat.

(b) Negara kesatuan dengan sistem desentralisasi.

Ciri-ciri negara kesatuan yang menerapkan sistem desentralisasi adalah dimana pemerintah pusat memberikan haknya kepada setiap daerah untuk mengatur dan mengurus urusan rumah tangganya sendiri. Pelimpahan wewenang tersebutlah yang dinamakan dengan otonomi yang kemudian dilaksanakan oleh daerah yang menjadi daerah otonom.

Dilanjutkan mengenai negara kesatuan dengan sistem desentralisasi oleh L.J Van Apeldoorn bahwa memang benar bahwa pemerintah pusat dapat memberikan haknya kepada provinsi namun dalam menerima kekuasaan tersebut provinsi tidak mempunyai hak mandiri untuk memutuskan tanpa adanya kesepakatan dengan pemerintah pusat. Hal tersebutlah yang disebut dengan negara kesatuan dimana kekuasaan tertinggi hanya dimiliki oleh pemerintah pusat.

Sedangkan menurut Thorsten V. Kalijarvi dalam Isjwara (1974) negara kesatuan sebagai negara dengan sentralisasi kekuasaan adalah negara-negara dimana seluruh kekuasaan dipusatkan pada satu atau beberapa organ pusat, tanpa pembagian kekuasaan antara pemerintah pusat dengan pemerintah bagian-bagian negara itu. Pemerintah bagian-bagian negara itu berguna sebagai penyelenggara administratifnya sendiri sedangkan bagian pmeerintah pusat yang bertindak sebagi wakil-wakil pemerintah pusat.

Dalam negara kesatuan, bagian-bagian negara biasa disebut dengan daerah. Sedangkan istilah derah ini merupakan istilah teknis bagi penyebutan suatu bagian teritorial yang berpemerintahan sendiri dalam rangka negara kesatuan yang dimaksud. Untuk lebih memahami istilah tersebut dapat ditambahkan bahwa kata daerah 
(gebiedsdeel) dimaksudkan lingkungan yang dijelmakan dengan membagi suatu kesatuan lingkungan yang disebut "wilayah" (gebied). Dengan kata lain, istilah "daerah" bermakna "bagian" atau unsur dari suatu lingkungan yang lebih besar sebagai suatu kesatuan.

Menurut Soemantri (1981) permasalahan yang terdapat dalam negara kesatuan adalah adanya pemberian kekuasaan pemerintah pusat kepada daerah-daerh otnom, bukanlah permasalahannya terletak pada konstitusinya.

Kelemahan dalam hubungan ini adalah Pemerintah pusat mempunyai alasan untuk mendominasi sistem kepemerintahannya agar negara kesatuan dan integritas negara tetap utuh. Akan tetapi alasan tersebut menjadi hambatan bagi pemerintah daerah untuk mengatur daerahnya sendiri dikarenakan ruang gerak yang diberikan pusat untuk mengelola rumah tangganya sangat minim. Sehingga peran dan hak dari pemerintah daerah terbatas.

Jika dilihat dari sudut pandang segi politik, E. Utrecht dalam bukunya Budiardjo (1991) menjelaskan adanya perbedaan prinsip atau keyakinan antara negara kesatuan dan negara federasi. Lebih jelasnya pendapat tersebut dapat diuraikan seperti pernyataannya di bawah ini:

"Pada permulaan perkembangan kenegaraan, perlu adanya sentralisasi kekuasaan supaya kekuatan-kekuatan yang bertujuan akan meruntuhkan kesatuan yang baru itu dapat dilenyapkan. Apabila ternyata kekuatan-kekuatan itu sudah tidak ada lagi, hiduo negara yang baru itu tidak terancam lagi oleh kekuatan-kekuatan yang bertujuan meruntuhkan kekuasaan, maka sentralisasi dapat dijadikan desentralisasi, bahkan lebih jauh lagi suatu desentralisasi yang yang bersifat federasi." 
Pemencaran penyelenggaraan negara dan pemerintahan dalam satuan-satuan teritorial yang lebih kecil dapat diwujudkan dalam bentukbentuk dekonsentrasi teritorial, satuan otonomi teritorial, atau federal. Selain bentuk-bentuk utama di atas, ada beberapa cara yang lebih longgar seperti konfederasi, atau uni, tetapi dua bentuk terakhir ini tidak dapat disebut sebagai suatu pemencaran penyelenggaraan negara dan pemerintahan karena tidak diikuti dengan pembagian kekuasaan atau wewenang. Masing-masing tetap secara penuh menjalankan kekuasaan sebagai negara.

Dari bentuk-bentuk utama pemencaran penyelenggaraan negara dan pemerintahan di atas, akan dijumpai paling kurang tiga bentuk hubungan antara pusat dan daerah. Pertama, hubungan pusat dan daerah menurut dasar dekonsentrasi teritorial. Kedua, hubungan pusat dan daerah menurut dasar otonomi teritorial. Ketiga, hubungan pusat dan daerah menurut dasar federal.

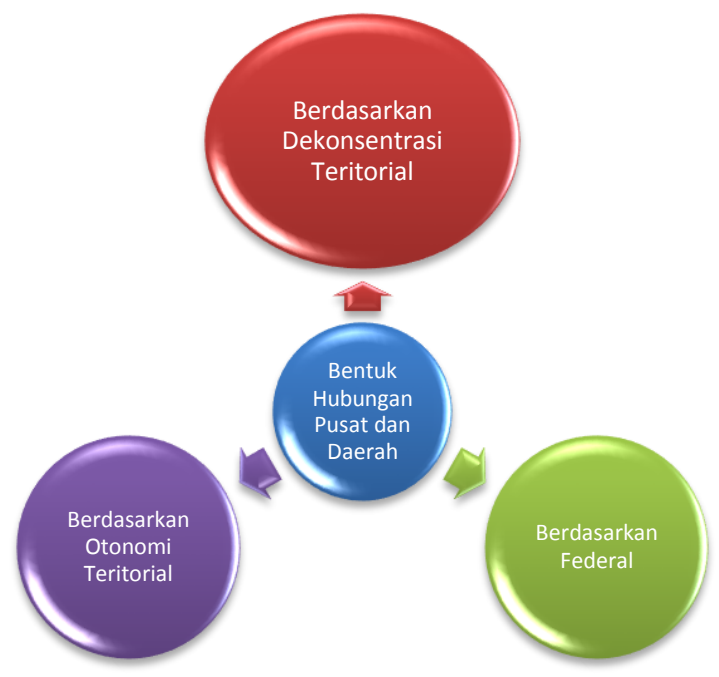

Gambar 2.2 


\section{Bentuk Hubungan antara Pusat dan Daerah}

Selain perbedaan, ada persamaan persoalan hubungan-hubungan pusat dan daerah dalam ketiga bentuk tersebut, terutama hubungan pusat dan daerah menurut dasar otonomi teritorial dan hubungan pusat dan daerah menurut dasar federal. Perbedaannya, dasar hubungan pusat dan daerah menurut dasar dekonsentrasi teritorial, bukan merupakan hubungan antara dua subyek hukum (publiek rechtspersoon) yang masing-masing mandiri. Satuan pemerintahan teritorial dekonsentrasi tidak mempunyai wewenang mandiri. Satuan teritorial dekonsentrasi merupakan suatu wewenang dengan departemen atau kementrian yang bersangkutan. Sifat wewenang satuan pemerintahan teritorial dekonsentrasi adlah delegasi atau mandat. Tidak ada wewenang yang berdasrakan atribusi. Urusan pemerintahan yang dilakukan satuan pemerintahan teritorial dekonsentrasi adalah urusan Pusat di daerah. persamaannya, baik dekonsentrasi maupun otonomi, sama-sama hanya menyelenggarakan pemerintahan di bidang administrasi negara. Baik dekonsentrasi maupun otonomi sama-sama bersifat administratiefrechttelijk, bukan staatsrechttelijk.

Hubungan pusat dan daerah atas dasar otonomi teritorial merupakan konsep dalam negara kesatuan. Satuan otonomi teritorial merupakan suatu satuan mandiri dalam lingkungan negara kesatuan yang berhak melakukan tindakan hukum sebagai subyek hukum untuk mengatur dan mengurus fungsi pemerintahan (administrasi negara) yang menjadi urusan rumah tangganya. Jadi, hubungan Pusat dan Daerah atas dasar otonomi teritorial memiliki kesamaan dengan hubungan pusat da daerah atas dasar federal yaitu hubungan antara dua subyek hukum yang masing-masing berdiri sendiri. Perbedannya, dalam otonomi teritorial, pada dasarnya seluruh fungsi kenegaraan dan pemerintahan ada dalam lingkungan pemerintah pusat yang 
kemudian dipencarkan kepada satuan-satuan otonomi. Pemencaran ini dapat dilakukan dengan beberapa cara. Pertama, undang-undang menetapkan secara tegas berbagai fungsi pemerintahan (administrasi negara) sebagai urusan rumah tangga daerah. cara-cara ini mirip dengan cara-cara dalam sistem federal yang merinci kekuasaan negara bagian. Kedua, pusat dari waktu ke waktu menyerahkan berbagai urusan baru kepada satuan otonomi. Ketiga, Pusat mengakui urusan-urusan pemerintahan tertentu yang "diciptakan" atau yang kemudian diatur dan diurus satuan otonomi baik karena tidak diatur dan diurus Pusat maupun atas dasar semacam Concurrent power. Keempat, membiarkan suatu urusan yang secara tradisional atau sejak semula dikenali sebagai fungsi pemerintahan yang diatur dan diurus satuan otonomi. Cara-cara penentuan urusan rumah tangga satuan otonomi ini akan menentukan suatu otonomi bersifat luas atau terbatas. Perbedaan lainnya adalah kekuasaan federal hanya mengikat sistem tata negara saja dan kekuasaan otonomi sebatas mengikat keadministratifannya saja..

C.F Strong mengatakan ada dua tipe yang selalu terlihat pada negara kesatuan yaitu terdapat supremasi yang diperoleh dari dewan perwakilan rakyat pusat dan tidak terdapatnya kedaulatan oleh badan-badan yang lainnya. Menurut van der Pot, setiap negara kesatuan dapat disusun dan diselenggarakan menurut asas dan sistem sentralisasi atau desentralisasi. Suatu pemerintahan sentralisasi dapat sepenuhnya dilaksanakan oleh dan dari pusat pemerintahan atau oleh pusat bersama-sama organnya yang dipencarkan di daerah-daerah. Sentralisasi yang disertai pemencaran organ-organ yang menjalankan sebagian wewenang pemerintahan pust di daerah dikenal sebagi dekonsentrasi. Desentralisasi akan di dpaat apabila kewenangan mengatur dan mengurus 
penyelenggaraan pemerintahan tidak semata-mata dilakukan oleh pemerintah pusat, melainkan oleh satuan-satuan pemerintahan tingkat lebih rendah yang mandiri bersifat otonom.

2. Konsepsi Desentralisasi

Sebagai konsep, desentralisasi tumbuh dan berkembang seiring dengan tuntutan dan kebutuhan negara demokrasi sejak lama. Pada tahun 1950-an menjadi tahun pertama yang memperdengarkan dan memperkenalkan adanya konsep desentralisasi dan konsep tersebut menjadi perhatian bagi negara-negara yang berkembang yang ingin memperkuat dan memberdayakan penyelenggaraan pemerintah daerah. Kejadian tersebut menjadi gelombang pertama dari adanya konsep desentralisasi. Gelombang kedua desentralisasi terjadi pada akhir tahun 1970-an utamanya di negara-negara sedang berkembang.

Aneka bentuk desentralisasi pada dasarnya dapat dibedakan menurut tingkat peralihan kewenangan. Kewenangan untuk merencanakan, memutuskan, dan mengatur dari pemerintahan pusat ke lembaga-lembaga yang lain. Ada empat bentuk utama desentralisasi, yaitu (1) dekonsentrasi, (2) delegasi ke lembagalembaga semi-otonom atau antar daerah, (3) pelimpahan kewenangan (devolusi) ke pemerintah daerah, dan (4) peralihan fungsi dari lembaga-lembaga negara ke lembaga swadaya masyarakat.

Pertama, dekonsentrasi mencakup redistribusi tanggung jawab administratif hanya di dalam badan pemerintahan pusat. Kedua, delegasi kewenangan untuk mengambil keputusan dan manajemen atas fungsifungsi khusus kepada lembaga-lembaga yang tidak berada di bawah kontrol langsung kementerian pemerintah pusat. Ketiga, bentuk desentralisasi yang lain berupaya menciptakan atau 
memperkokoh tingkat atau satua-satuan pemerintah independen melalui devolusi peran dan kewenangan.

Kelompok yang memaknai desentralisasi sebagai devolusi dan dekonsentrasi menyatakan bahwa bentuk konkret dari dianutnya asas ini adalah daerah otonom. Ciri utama dari daerah otonom adalah adanya lembaga perwakilan daerah dan eksekutif daerah yang berfungsi sebagai lembaga politik lokal. Mereka yang bergelut dengan keseharian politik di tingkt lokal, karenanya memahami betul dinamika sosial yang terjadi. Adalah logis apabila kepada mereka diberi hak untuk menentukan kebijakan pemerintahan sendiri, sesuai dengan harapan dan kondisi masyarakat senyatanya. Disini devolusi merupakan jawaban yang paling tepat. Konsekuensinya pada tataran pemerintahan lokal, lembaga perwakilan rakyat daerah (untuk kasus Indonesia: DPRD) menjadi aktor utama penentu kebijakan (Imawan, 2004).

Di kalangan ahli hukum Indonesia, desentralisasi didefenisikan secara beragam. Menurut RDH Koesoemahatmadja (1979), secara harfiah kata desentralisasi berasal dari dua penggalan kata bahasa latin. Yakni: de yang berarti lepas, dan centrum yang berarti pusat. Makna harfiah dari desentralisasi adalah melepaskan diri dari pusat. Dalam makna ketatanegaraan, desentralisasi adalah penyerahan kekuasaan pemerintahan dari pusat kepada daerah-daerah. desentralisasi merupakan staatkundige decentralisatie (desentralisasi ketatanegaraan atau lebih sering disebut dengan desentralisasi politik), bukan ambtelijke decentralisatie, seperti halnya dekonsentrasi. Deknsentrasi merupakan ambtelijke decentralisatie, disebut pula delegatie van bevoegheid, yakni pelimpahan kewenangan dari alat perlengkapan negara pusat kepada instansi bawahan untuk melaksanakan pekerjaan tertentu dalam penyelenggaraan pemerintahan. Pemerintah pusat tidak kehilangan 
kewenangannya, instansi bawahan melaksanakan tugas atas nama pemerintah pusat. Suatu delegatie van bevoegheid bersifat instruktif, rakyat tidak dilibatkan. Lebih tepat hubungan dekonsentrasi dinamakan mandaat van bevoegheid. Sedangkan menurut R. Tresna, merupakan suatu pelimpahan kewenangan (delegation of authority) dalam staatskundige decentralisatie berakibat beralihnya kewenangan pemerintahan pusat secara tetap. Pemerintah pusat kehilangan kewenangan yang dilimpahkan, beralih kepada pemerintah daerah.

Desentralisasi adalah strategi mendemokratisasi sistem politik dan menyelaraskan pencapaian pembangunan berkelanjutan yang merupakan isu yang selalu ada dalam praktek administrasi publik. Berlawanan dengan sentralisasi dimana kekuasaan dan pengambilan keputusan berkonsentrasi pada pusat atau eselon atas, desentralisasi memperkenankan level kekuasaan pemerintahan yang lebih rendah atau dibawah dalam menentukan sejumlah isu yang langsung mereka perhatikan. Desentralisasi biasanya menyerahkan secara sistematis dan rasional pembagian kekuasaan, kewenangan dan tanggung jawab dari pusat kepada pinggiran, dari level bawah, atau dari pemerintah pusat kepada pemerintah lokal (daerah).

Dalam sistem pemerintahan lokal, disamping dekonsentrasi dan desentralisasi, diselenggarakan pula tugas pembantuan (medebewind; coadministration; co-government) oleh pemerintah kepada daerah otonom. Berdasar asas ini, Pemerintah menetapkan kebijakan makro, sedangkan daerah otonom membuat kebijakan mikro beserta implementasinya.

Menurut Koesoemahatmadja (1979), medebewind atau zelfbestuur sebagai pemberian kemungkinan kepada pemerintah / pemda atau yang tingkatannya lebih atas untuk minta bantuan kepada pemda / 
pemda yang lebih rendah agar menyelenggarakan tugas atau urusan rumah tangga (daerah yang tingkatannya lebih atas tersebut). Istilah zelfbestuur merupakan padanan dari kata self-government yang berarti sebagai kegiatan pemerintahan di tiap bagian dari Inggris yang dilakukan oleh wakil-wakil dari yang diperintah. Di belanda zelfbestuur diartikan sebagai membantu penyelenggaraan kepentingan-kepentingan pusat atau daerah-daerah yang tingkatannya lebih atas oleh alat-alat kelengkapan dari daerahdaerah yang lebih bawah. Dalam menjalankan medebewind itu, urusan-urusan yang diselenggarakan oleh pemerintah daerah masih tetap merupakan urusan pusat, Daerah yang lebih atas. Atau biasanya disebut dengan mandat.

Tujuan diberikannya tugas pembantuan adalah untuk meningkatkan efektivitas dan efisiensi penyelenggaraan pembangunan serta pelayanan umum kepada masyarakat. Selain itu pemberian tugas pembantuan juga memperlancar pelaksanaan tugas dan penyelesaian permasalahan serta membantu mengembangkan pembangunan daerah dan desa sesuai dengan potensi dan karakteristiknya.

\subsection{Rentang Perdebatan teori desentralisasi: Rondinelli vs Slater}

Rondinelli (1983) mendefinisikan desentralisasi sebagai penyerahan tanggung jawab perencanaan, manajemen sumber daya, serta alokasi dana dari pemerintah pusat dan lembaga-lembaganya kepada unit lapangan kementrian pemerintah pusat, unit di bawah pemerintah atau tingkat pemerintahan, daerah, otoritas regional atau fungsional, otoritas publik yang semiotonom atau perusahaan, dan organisasi swasta atau nonpemerintah (NGOs).

Desentralisasi memiliki empat bentuk yang dapat dibagi dalam tingkat otoritas dan kekuasaan, atau ruang lingkup fungsinya. Bentuk 
yang pertama yaitu dekonsentrasi, yang merupakan pelimpahan wewenang dari pemerintah pusat kepada pemerintah daerah. Menurut Rondinelli (1983) bahwa pelimpahan suatu fungsi dari pemerintah pusat yang diberikan haknya kepada pemerintah daerah yang menjadi bagian dari pemerintah pusat seperti melalui perpindahan beban kerja atau perpindahan tanggung jawab dari departemen di pusat kepada petugas lapangan disebut dengan dekonsentrasi. Namun penyerahan kewenangan ini dapat digunakan pada ukuran dan porsi kewenagan yang berbeda-beda pula. Kondisi tersebut dapat dimisalkan dengan pendapat masyarakat lokal yang tidak terwadahi dengan adanya dekonsentrasi sehingga pendapat tersebut tidak dapat dijadikan sebagai langkah pengambilan keputusan namun hanya sebatas pada proses pengadministrasian saja (Seymour \& Turner, 2002).

Selanjutnya adalah delegasi. Menurut Rondinelli (1983) delegasi merupakan pemberian wewenang yang dianugrahkan dikarenakan adanya wewenang yang diberikan atau dilimpahkan. Wewenang tersebut dianggap sebagai oemeberian wewenang yang berasal dari tingkat tinggi yang kemudian secara hukum diturunkan dari tingkatketingkat. Jika dikaitkan dengan administrasi negara makka pendelegasian tersebut berada pada organisasi yang semi otonom. Delegasi pada organisasi semi otonom adalah dimana keadaan yang tidak sepenuhnya diberikan kepada tingkat yang berada di bawahnya. Hal tersebut dapat dicontohkan seperti daerah yang mempunyai wewenang akan pengadaan barang jasa, penerimaan karyawan baru, merencanakan anggaran, pemutusan hubungan kerja dan lain sebagainya. Hal tersebut menjelaskan bahwa pemerintah daerah adalah agen yang bertanggung jawab penuh kepada pemerintah pusat. Dapat disimpulkan bahwa pemberian pendelegasian untuk mengambil sebuah keputusan yang tidak 
berada dibawah pengawasan langsung oleh Pemerintah Pusat. Kegiatan ini dapat diberikan kepada perusahaan publik atau unit pelaksana proyek khusus.

Bentuk desentralisasi yang ketiga yaitu devolusi (devolution). Menurut Rondinelli (1983) devolusi merupakan pengalihan fungsi atau otoritas pengambilan keputusan kepada pemerintah daerah yang tergabung secara hukum, seperti negara, provinsi, kabupaten atau kota. Devolusi adalah kegiatan substansial diluar kontrol langsung pemerintah pusat yang berguna untuk menciptakan dan menguatkan finansial atau hukum terhadap pemerintah daerah. Dalam devolusi, unit pemerintah daerah bersifat otonom dan mandiri. Status hukum yang dimiliki pemerintah daerah bersifat terpisah atau berbeda dari pemerintah pusat. Pada umumnya, dalam melaksanakan kewenangan eksklusifnya pemerintah daerah melaksanakan fungsinya sesuai dengan batas-batas letak geografis yang dimiliki secara jelas dan disetujui secara hukum. Menurut Rondinelli (1983) pemerintah daerah memiliki kewenangan untuk mengelola dan membuat undang-undang untuk meningkatkan pendapatan dan menyusun perbelanjaan daerah.

Bentuk desentralisasi yang keempat yaitu privatisasi, merupakan pergeseran tanggung jawab untuk kegiatan dari sektor publik kepada organisasi swasta atau quasipublic yang bukan bagian dari struktur pemerintah. Organisasi-organisasi diberi tanggung jawab, lisensi, mengatur, atau mengawasi masyarakat yang menjadi member, dimana sebelumnya fungsi tersebut dilakukan atau diatur oleh pemerintah. Menurut Rondinelli (1983) pemerintah dapat melaksanakan desentralisasi dalam beberapa kasus dengan pemindahan tanggung jawab kepada perusahaan swasta dalam penyediaan layanan yang sebelumnya dilakukan oleh perusahaan milik negara atau publik. Pemerintah juga dapat melimpahkan 
tanggung jawab kepada organisasi yang mewakili berbagai kepentingan dalam masyarakat yang didirikan dan dioperasikan oleh anggota organisasi mereka. Misalnya koperasi petani, asosiasi kredit, organisasi pembangunan desa, serikat buruh, atau organisasi perempuan dan karang taruna.

Desentralisasi merupakan sebuah harapan untuk menanggulangi permasalahan pemerintah seperti kelebihan beban kerja, administrasi dan komunikasi yang lambat dalam penyelenggaraan pemerintahan. Hal tersebut dikemukakan oleh Rondinelli (1983). Dengan adanya konsep desentralisasi diperkirakan respon pemerintah kepada masyarakat akan meningkat dengan cara memberikan pelayanan yang lebih baik secara kuantitas dan kualitas. Desentralisasi diasumsikan sebagai cara untuk mengelola pembangunan ekonomi nasional lebih efektif dan efisien. Desentralisasi juga memungkinkan para pejabat pemerintah pusat lebih rensponsif terhadap permasalahan yang ada di daerah. Hal itu karena desentralisasi merupakan sarana bagi pemerintah pusat untuk meningkatkan kemampuan dalam mendapatkan informasi yang lebih akurat mengenai kondisi daerah. Menurut teori, desentralisasi memberikan kewenangan yang lebih besar kepada pemerintah daerah dalam pengambilan keputusan sehingga memungkinkan program pemerintah akan selesai lebih cepat. Karena prosedur yang lamban selama ini cenderung dikaitkan dengan administrasi sentralistik.

Menurut Rondinelli \& Cheema (2002) desentralisasi dapat menjadi perkembangan yang positif bagi negara-negara berkembang. Desentralisai juga memberi kesempatan yang lebih besar bagi kelompok-kelompok politik, suku, agama, dan etnis yang berbeda untuk merepresentasikan kelompoknya dalam proses pengambilan keputusan. Sehingga alokasi sumber daya dan dana dari pemerintah 
dapat lebih merata. Desentralisasi juga dapat meningkatkan stabilitas politik dan persatuan nasional dengan memungkinkan populasi yang berbeda untuk mengambil bagian lebih leluasa dalam pengambilan keputusan, sehingga meningkatkan demokratisasi dalam sistem politik.

Dalam perjalannya ternyata pelaksanaan desentralisasi hanya sebagai kebutuhan pragmatis tertentu sehingga menimbulkan banyak perdebayan. Realita tersebut dirangkum oleh Seymour dan Turner (2002) yang diperoleh dari penelitian-penelitian yang dilakukan oleh ilmuan-ilmuan yang tersebar di negara-negara lainnya. Beberapa politisi negara meyakini bahwa dengan pelaksanaan kebijakan desentralisasi mereka bisa meningkatkan popularitas jangka panjang meskipun kekuatan mereka menurun dalam jangka pendek. Para politisi negara terpaksa untuk melakukannya, seperti yang terjadi di Brazil pada tahun 1980 gubernur yang mengontrol jalur karir politisi nasional, menggunakan pengaruhnya menuntut agar pemerintah menjadi lebih terdesentralisasi. Keputusan untuk menjalankan desentralisasi juga dipengaruhi oleh berbagai macam tekanan, termasuk tekanan dari pemberi pinjaman internasional, seperti Bank Dunia dan International Monetary Fund (IMF). Kedua lembaga tersebut sangat mendukung upaya desentralisasi, dan percaya hal itu menjadi bagian sentral dari proses demokratisasi dan berguna dalam memfasilitasi ekonomi pasar kapitalis gaya Barat. Selain dari internasional, tekanan juga datang dari dalam negeri yang berasal dari berbagai pemangku kepentingan yang berbeda. Misalnya, perubahan rezim telah menciptakan kekosongan kekuasaan yang memungkinkan politisi dan kelompok-kelompok di daerah untuk memaksa otonomi yang lebih besar. Tujuan elit tersebut hanyalah untuk mengisi kekosongan jabatan-jabatan publik di daerah. Perdebatan tersebut bahkan terus 
berlanjut antara teori neo-Marxis dan neo-liberal (Slater, 1990; Rondinelli, 1990).

Rondinelli melakukan analisis kebijakan desentralisasi dengan mengembangkan kerangka kerja eknomi politik terintegrasi diantaranya :

a. Karakteristik/Penciri pada komoditas dan layanan publik beserta penggunannya.

b. Alternatif pada pembiayaan dan keorganisasian dalam penyediaan/pemberian layanan.

c. Penyusnan pada instansi yang layak bagi penyediaan layanan.

d. Pra syarat sosio-ekonomi dan politik yang berpengaruh pada desain kebijakan dan implementasi program.

e. Intervensi/campur tangan pada kebijakan yang layak dan instrumen yang memberi arah pada formulasi kebijakan yang menyangkut desain program dan proyek, bantuan teknis dan finansial, serta evaluasai program.

Selanjutnya Slater memberikan kritikan pada pendapat tulisan Rondinelli. Slater berpendapat bahwa Rondinelli mengabaikan dominasi politik dan kekuasaan, serta pendekatannya berdasarkan pandangan resmi USAID dan Bank Dunia. Slater menggunakan pendekatan neo-marxist dengan menunjukkan bahwa sesungguhnya terdapat kekuatan sistem internasional didalamnya, sehingga desentralisasi bukanlah menjadi persoalan politik dalam negeri saja. Melainkan, pada area lokal Slater juga megemukakan adanya kelompok elit lokal yang menjadi penghambat dalam partisipasi masyarakat di pemerintahan daerah.

Rondinelli setuju dengan pendapat Slater yang menyatakan bahwa terdapat implikasi/hubungan politik yang lebih luas terhadap 
desentralisasi. Namun ia tidak menyetujui tuduhan Slater yang menilai karyanya sebagai "official discourse" dan yang menganggapnya gugur. Hal tersebut karena pandangan desentralisasinya tidak sesuai dengan teori neo-marxist.

Slater menerima penjelasan dari Rondinelli, dan membuat empat perbedaan antara dirinya dan Rondinelli, yaitu :

a. Rondinelli tidak mau memberikan pengakuan bahwa sesuatu yang sangat diakui oleh Slater.

b. Rondinelli dianggap telah menggunakan secara silih berganti istilah negara, pemerintah, dan bangsa dalam pengaruhnya terhadap desentralisasi dengan tidak membedakannya.

c. Dampak pada gerakan-gerakan sosial terhadap perdebatan sentralisasi atau desetralisasi tidak menjadi perhatian secara serius oleh Rondinelli.

d. Perbedaan meluas pada persoalan tantangan terhadap perubahan revolusioner.

Meskipun para ahli memiliki perspektif teoritis yang berbeda, namun mereka setuju bahwa desentralisasi belum tentu menghasilkan demokrasi dan dapat memfasilitasi pembangunan seperti yang dialami oleh negara berkembang saat ini. Bahkan, beberapa kajian telah melakukan evaluasi pada desentralisasi yang menunjukkan bahwa kesuksesan/keberhasilan yang nyata jarang ditemukan. Beberapa penelitian yang telah dilakukan menunjukkan bahwa desentralisasi telah menyebabkan penurunan pada kualitas pelayanan dalam beberapa kasus, terciptanya disparitas antar daerah, dan peningkatan pada tindak korupsi (Seymour \& Turner, 2002). Studi yang telah dilakukan oleh Blair (dalam Seymour \& Turner, 2002) di 6 (enam) negara yakni Bolivia, Honduras, India, Mali, Filipina, dan Ukraina menunjukkan fakta bahwa walaupun otonomi 
yang besar dimiliki pemerintah daerah, namun masih terjadi kegagalan dalam membantu mengentaskan kemiskinan. Hal ini dikarenakan kelompok elit lokal yang diberi kekuasaan (melalui desentralisasi), mengarahkan semua kemanfaatan untuk kepentingan diri mereka sendiri.

\subsection{Rentang Pengertian Desentralisasi}

Desentralisasi merupakan konsekuensi dari demokratisasi. Tujuannya adalah membangun good governane mulai dari akar rumput politik. Desentralisasi adalah asas penyelenggaraan pemerintahan yang dipertentangkan dengan sentralisasi. Friedman dalam Haris (2007) menjelaskan bahwa desentralisasi menghasilkan pemerintahan lokal (local government), disana terjadi "a superior government assigns responsibility, authority, or function to lower government unit that is assumed to have some degree of authority". Adanya pembagian kewenangan serta tersedianya ruang gerak yang memadai untuk memaknai kewenangan yang diberikan kepada unit pemerintahan yang lebih rendah (pemerintah lokal), merupakan perbedaan terpenting antara konsep desentralisasi dan sentralisasi. Namun perbedaan konsep yang jelas ini menjadi remang-remang tatkala diterapkan dalam dinamika pemerintahan yang sebenarnya. Ada yang memaknai desentralisasi sebagai desentralisasi politik (devolusi) dan desentralisasi administratif (dekonsentrasi). Adapula yang beranggapan bahwa desentralisasi adalah devolusi. Perbedaan ini muncul dari pemaknaan terhadap istilah desentralisasi itu sendiri. Namun para ahli politik percaya bahwa menganutnya asas desentralisasi menjadikan suatu kebijakan yang tepat sasaran dengan daerahnya sendiri. Perbedaan menyeruak tatkala cara terbaik untuk mewujudkan keinginan ini.

Kelompok yang memaknai desentralisasi sebagai devolusi dan dekonsentrasi menyatakan bahwa bentuk konkret dari dianutnya 
azas ini adalah adanya daerah otonom. Ciri utama dari daerah otonom adalah adanya lembaga perwakilan daerah dan eksekutif yang berfungsi sebagai lembaga politik lokal. Mereka yang bergelut dengan keseharian politik di tingkat lokal, karenanya memahami betul dinamika sosial yang terjadi (Haris, 2007).

Desentralisasi secara etimologis berasal dari bahasa Latin yang terdiri dari kata de dan centrum. De berarti lepas, dan centrum berarti pusat, sehingga desentralisasi berarti melepaskan diri dari pusat. Pengertian tersebut bukan berarti daerah melepaskan diri dari ikatan negara dan dapat berdiri sendiri. Menurut perspektif ketatanegaraan, desentralisasi merupakan pemberian otonomi ke daerah untuk menjadi daerah otonom. Artinya daerah-daerah diberi pelimpahan kekuasaan dari pemerintah pusat untuk mengurus rumah tangganya sendiri.

Logemann berpendapat bahwa desentralisasi merupakan adanya kekuasaan bertindak merdeka (vrije beweging) yang diberikan kepada satuan-satuan kenegaraan yang memerintah daerahnya sendiri, yaitu kekuasaan yang berdasarkan inisiatif sendiri yang disebut otonomi. Istilah tersebut oleh Van Vollenhoven dinamakan eigenmeesterschap (Utrecht, 1966). Wesber sebagaimana dikutip Surianingrat (1981) menjelaskan mengenai desentralisasi yang merupakan pembagian dan pendistribusian administrasi pemerintahan, mengeluarkan dari pusat atau tempat konsentrasi. Disisi lain Mawhood (1983) mengartikan desentralisasi sebagai pelimpahan kekuasaan dari pemerintah pusat ke pemerintah daerah. Joeniarto (1992) berpendapat bahwa desentralisasi merupakan pemberian wewenang kepada pemerintah lokal dari pemerintah negara untuk mengatur dan mengurus bidang tertentu sebagai urusan rumah tangganya sendiri. Berbeda dengan Sujito (1990) yang menjelaskan bahwa desentralisasi adalah pelimpahan kewenangan Pemerintah kepada pihak lain untuk dilaksanakan. Sedangkan 
Muslimin (1986) menjelaskan bahwa desentralisasi merupakan pelimpahan kewenangan-kewenangan oleh pemerintah pusat pada badan-badan otonom (swatantra) yang berada di daerah-daerah.

Otonomi daerah merupakan esensi pemerintahan desentralisasi. Istilah otonomi berasal dari bahasa yunani yang terdir dari kata autos dan nomos. Autos berarti sendiri dan nomos berarti undang-undang. Sehingga otonomi berarti membuat perundang-undangan sendiri (zelfwetgeving). Namun dalam perkembangannya, konsep otonomi daerah juga utamanya mencakup zelfbestuur (pemerintahan sendiri). C.W. Vander Pot menjelaskan konsep otonomi daerah sebagai eigen huishouding (menjalankan rumah tangganya sendiri). Sedangkan pengertian otonomi daerah menurut Undang-Undang Nomor 32 Tahun 2004 adalah hak, wewenang, dan kewajiban daerah otonom untuk mengatur dan mengurus sendiri urusan pemerintahan dan kepentingan masyarakat setempat sesuai dengan peraturan perundang-undangan (Chalid, 2005).

Hossein mengungkapkan bahwa local government merupakan sebuah konsep yang mempunyai tiga arti. Pertama, pemerintahan lokal yang seringkali dipertukarkan dengan local authorithy yang mengacu pada organ yakni council dan mayor dimana rekrutmen pejabatnya didasarkan pada pemilihan. Kedua mengacu pada pemerintahan lokal yang dilakukan oleh pemerintahan lokal. Arti kedua ini lebih mengacu pada fungsi. Ketiga, local government bermakna daerah otonom. Hossein menjelaskan bahwa pembentukan daerah otonom yang secara serentak merupakan kelahiran status otonomi berdasarkan aspirasi dan kondisi objektif dari masyarakat yang berada diwilayah tertentu sebagai bagian dari bangsa dan wilayah nasional. Menurut Muluk (2007) masyarakat yang menuntut otonomi melalui desentralisasi menjelma menjadi daerah otonom sebagai kesatuan masyarakat hukum yang 
berwenang mengatur dan menangani urusan pemerintahan menurut prakarsa sendiri berdasarkan aspirasi masyarakat.

Otonomi bukan dimaksudkan untuk proses kemerdekaan daerah yang berarti memiliki kedaulatan penuh dan terpisah. Otonomi juga bukan sebagai bentuk adanya kebebasan secara mutlak suatu daerah. Melainkan kesempatan bagi daerah agar dapat berkembang sesuai potensi yang dimiliki. Hal itu berarti otonomi harus digunakan untuk mengoptimalkan potensi lokal baik dari segi lingkungan, alam, dan kebudayaan. Namun optimalisasi yang dilakukan harus dipandang sebagai proses pengembangan daerah untuk mewujudkan kehidupan masyarakat yang lebih sejahtera, bukan semata-mata mengeksploitasi sumber daya alam (Tim Lapera, 2001). Gerald S. Maryanov dalam Chalid (2005) berpendapat bahwa desentralisasi merupakan proses memberikan otonomi kepada masyarakat di wilayah tertentu. Desentralisasi dan otonomi daerah diibaratkan sebagai dua sisi mata uang. G. Shabbir Cheema dan Dennis A. Rondinelli (1992) mendefinisikan desentralisasi dengan menitikberatkan pada perspektif yang lebih luas dan fleksibel. Menurut mereka, desentralisasi adalah perpindahan perencanaan, pengambilan keputusan, atau kewenangan administratif dari pemerintah pusat ke organisasi bidangnya, unit administratif daerah, semi otonomi dan organisasi parastatal, pemerintahan daerah, atau organisasi-organisasi nonpemerintah.

Sehubungan dengan perihal yang telah diungkapkan sebelumnya, G. Shabbir Cheema dan Dennis A. Rondinelli pada tahun 1992 mengungkapkan adanya ciri-ciri desentralisasi yaitu sebagai berikut:

a. Mengenai struktur kepemerintahan, kekuasaan yang diberikan secara administratif disebut dengan dekonsentrasi.

b. Hak dalam mengatur dan mengambil sebuah keputusan yang jelas yang diberikan kepada organisasi-organisasi merupakan sebuah pelimpahan wewenang yang dapat dikatakan sebagai 
delegasi. Delegasi dilakukan mengingat bahwa tidak semua dapat terpantau oleh pemerintah.

c. Pihak swasta memberikan kepada organisasinya mengenai kewenangan untuk bertanggung jawab secara penuh dalam merencanakan dan mempertanggung jawabkan tugas atau fungsi-fungsi tertentu yang disebut dengan swastanisasi. Sedangkan mengenai makna devolusi dapat dijabarkan dengan pelimpahan tugas dan hak yang diberikan pemerintah pusat kepada kepemerintahan daerah otonom atau pemerintah ditingkat bawahnya.

Sedangkan pengelompokan yang dilakukan oleh John M. Cohen dan Stephen B. Peterson (1999) mengenai konsep desentralisasi dapat dijelaskan sebagai berikut: Berdasarkan sejarah.

1. Berdasarkan hirarki dan fungsi.

2. Pendekatan yang timbul dari adanya permasalahan yang dihasilkan dari adanya pengawasan yang dilakukan sebelumnya;

3. Hasil dari pelayanan dan barang menjadi titik terpenting terhadap kebijakan-kebijakan yang diputuskan dan dilaksanakan, sehingga dapat dinilai berhasil atau tidaknya keputusan kebijakan tersebut untuk memenuhi tanggung jawab dan hak yang diberikan;

4. Suatu pengalaman menjadi dasar bagi negara agar selalu dapat bercermin dari apa yang dilakukan di masa lampau yang berguna bagi pembelajaran mengenai pemahaman arti dari sebuah proses;

5. Berdasarkan pada tujuannya.

\subsection{Derajat Desentralisasi}


Derajat desentralisasi kewenangan pemerintahan ke daerah, maka daerah akan mengalami proses pemberdayaan yang signifikan. Kemampuan prakarsa dan kreatifitas mereka akan terpacu, sehingga kapabilitasnya dalam menganalisis berbegai masalah domestik akan lebih kuat. Desentralisasi merupakan simbol adanya Thrust (kepercayaan) dari pemerintah pusat ke pemerintah daerah, ini akan dengan sendirinya akan mengembalikan harga diri pemerintah dan masyarakat daerah, kalau dalam sistem yang sentralistik mereka tidak bisa berbuat banyak dalam mengatasi berbagai masalah, dalam sistem otonomi ini mereka ditantang untuk secara kreatif menemukan solusi-solusi dari berbagai masalah yang dihadapi.

Menurut Muluk (2006) faktor-faktor derajat desentralisasi sebagai berikut :

a. Derajat desentralisasi dapat dilihat dari fungsi atau urusan yang dijalankan pemerintah daerah. Semakin banyak fungsi yang disentralisasi, maka semakin tinggi pula derajat desentralisasinya.

b. Terdapat dua jenis pendelegasian fungsi, yakni open-ed arrangement atau general competence dan ultravires doctrine. Jika suatu pemerintah daerah memiliki fungsi atas tipe pendelegasian general competence, maka dapat dianggap derajat desentralisasinya lebih besar.

c. Jenis kontrol pemerintah pusat terhadap pemerintah daerah, kontrol refresif derajat desentralisasinya lebih besar dan pada kontrol yang bersifat preventif.

d. Berkaitan dengan keuangan yang menyangkut sejauh mana adanya desentralisasi pengambilan keputusan, baik tentang penerimaan maupun pengeluaran pemerintah daerah.

e. Tentang metode pembentukan pemerintah daerah. derajat desentralisasi akan lebih tinggi jika sumber otoritas daerah 
berasal dari ketetapan legislatif dari pada pendelegasian dan eksekutif.

f. Derajat ketergantungan fungsional pemerintah daerah terhadap pemerintah pusat, semakin besar persentase bantuan pemerintah pusat daripada pemerintah asli daerah, berarti semakin besar pula ketergantungan daerah tersebut kepada pemerintah pusat, Hal ini berarti derajat desentralisasinya lebih rendah.

g. Besarnya wilayah pemerintahan daerah, ada anggapan bahwa semakin luas wilayahnya, maka semakin besar derajat desentralisasinya. karena pemerintah daerah lebih dapat mengatasi persoalan-persoalan dominasi pusat atas daerah, meskipun demikian hubungan antara besaran wilayah dengan kontrol masih terbuka untuk diperdebatkan.

h. Politik partai, jika perpolitikan partai ditingkat lokal masih di dominasi oleh organisasi politik nasional, maka derajat desentralisasinya dianggap lebih rendah dari pada perpolitikan ditingkat lokal lebih mandiri dan organisasi politik nasional.

Faktor lainnya adalah struktur dan sistem pemerintahan desentralisasi. Sistem pemerintahannya yang sederhana dianggap kurang desentralisasi bila dibandingkan dengan sistem kompleks. Menurut Said (2005) sekurangnya ada empat perspektif yang mendasari segi positif desentralisasi :

a. Desentralisasi adalah sarana untuk demokrasi.

b. Desentralisasi membantu meningkatkan kualitas dan efisiensi pemerintah.

c. Desentralisasi dapat mendorong stabilitas dan kesatuan nasional.

d. Desentralisasi memajukan pembangunan daerah. 
Menurut Ichsan, Supriyono \& Muluk (2006) faktor yang mempengaruhi penyelenggaraan desentralisasi sebagai berikut :

a. Utamanya berkaitan dengan peran birokrasi lokal, keberadaan faktor tersebut dapat disajikan landasan bagi penempatan model peran birokrasi pemerintah daerah di Indonesia.

b. Dan segi ekonomi dapat diketahui peran sektor publik lebih mendominasi penyediaan layanan publik dan pada sektor pasar (Strong Public Sector). Hal ini tidak berarti bahwa keberadaan sektor pasar tidak ada sama sekali, namun perananya kalah dominan jika dibandingkan dengan sektor publik. Selain itu, terdapat kecenderungan semakin menguatnya sektor publik yang diikuti dengan motivasi pejabat daerah yang lebih mengedepankan sektor ini.

Dari dimensi pemerintahan dapat dikatakan bahwa pemerintah daerah memiliki peran kuat dalam penyediaan layanan publik (Strong Local Government). Menurut Joseph Riwu (2008) mengenai faktorfaktor penyelenggaraan desentralisasi sebagai berikut :

a. Dilihat dari sudut politik sebagai permainan kekuasaan (game theory), desentralisasi dimaksudkan untuk mencegah penumpukan kekuasaan pada satu pihak saja yang pada akhirnya dapat menimbulkan tirani.

b. Dalam bidang politik, penyelenggaraan desentralisasi dianggap sebagai tindakan pendemokrasian, untuk menarik rakyat ikut serta dalam pemerintahan dengan melatih diri dalam mempergunakan hakhak demokrasi.

c. Dari sudut organisasi pemerintahan, Alasan mengadakan pemerintah daerah (desentralisasi) adalah sematamata untuk mencapai suatu pemerintahan yang efisien, apa yang 
dianggap lebih utama untuk diurus oleh pemerintah setempat, pengurusannya diserahkan pada daerah.

d. Dari sudut cultural, desentralisasi perlu diadakan supaya perhatian dapat sepenuhnya ditumpukan kepada kekhususan suatu daerah, seperti geografi, keadaan penduduk, kegiatan ekonomi, watak kebudayaan atau latar belakang sejarahnya.

e. Dari sudut kepentingan pembangunan ekonomi, desentralisasi diperlukan karena Pemenintah Daerah dapat lebih banyak dan secara langsung membantu pembangunan tersebut.

\section{Quiz}

Otonomi selama ini dianggap sebagai pintu masuk bagi pelaksanaan kekuasaan yang lebih baik dalam rangka pelaksanaan asas desentralisasi, tapi ternyata otonomi malah menciptakan benihbenih konflik baru yang mengarahkan derah pada posisi yang berhadap-hadapan saling bersaing dalam memperebutkan sumber daya yang ada.

Gunung Kelud yang terletak diantara tiga kabupaten yaitu Blitar, Malang, dan Kediri kini menjadi objek yang diperebutkan kedua Pemerintah Daerah (Pemda) Kabupaten Blitar dengan Kabupaten Kediri. Menjadi menarik saat Gunung Kelud yang merupakan gunung berapi aktif dan terletak diantara tiga kabupaten, tetapi diklaim hanya oleh Pemda Kabupaten Blitar dan Kabupaten Kediri bahwa mereka pemilik sahnya. Pemda Kabupaten Blitar menganggap Gunung Kelud perlu diperjuangkan karena dianggap sebagai batas wilayahnya. Sedangkan, Pemda Kabupaten Kediri memperjuangkan Gunung Kelud karena pembangunan infrastruktur di Gunung Kelud dilakukan olehnya. 
Konflik perbatasan kedua kabupaten tersebut terjadi pada rentang waktu yang cukup lama (tahun 2001-sekarang) tetapi belum menemukan kesepakatan, artinya Gunung Kelud belum memiliki pemilik yang sah. Meskipun, Pemda Kabupaten Kediri telah menganggap final Surat Keputusan (SK) Gubernur Jawa Timur Nomor 188 Tentang Penegasan Batas Wilayah yang menyebutkan Gunung Kelud masuk wilayah Kabupaten Kediri tetapi sampai saat ini, Pemda Kabupaten Blitar dan masyarakat Kabupaten Blitar masih belum legowo dengan keputusan Gubernur Jawa Timur. Sikap legowo dalam sebuah konflik menjadi hal penting, karena berkaitan dengan rawannya "legitimasi otoritas" [keabsahan dan penghormatan terhadap otoritas yang melekat pada posisi] seperti yang dikonsepkan oleh Ralf Dahrendorf. Artinya, turunnya SK gubernur 188 tersebut yang telah memberikan hak milik secara legal kepada Pemda Kabupaten Kediri, tetapi posisi legalitas kepemilikan akan selalu rawan untuk digugat legalitasnya apabila kesepakatan terbentuk karena paksaan dan tidak dengan sikap legowo, dengan kata lain konflik sangat mungkin dapat terjadi kembali dan proses konflik menjadi tidak pernah berakhir. 


\section{Kediri dan Blitar "Rebutan" Gunung Kelud}

Selasa, 17 Mei 2016 | 19:29 WIB

\section{0}

Komentar

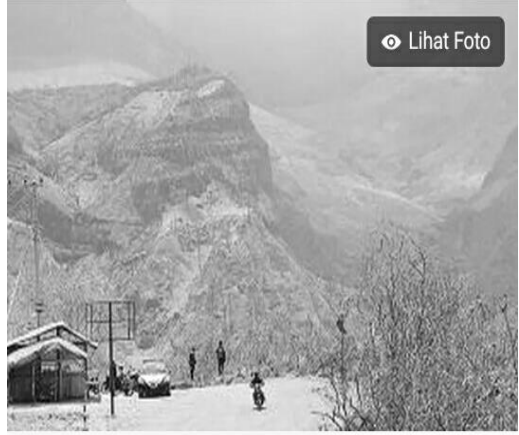

KOMPAS/DEFRI WERDIONO

Beberapa wisatawan, Selasa (11/3/2014), melihat kawasan sekitar kawah Gunung Kelud dari jarak sekitar 4 kilometer di jalan utama menuju kawah di Desa Sugihwaras, Ngancar, Kabupaten Kediri, Jawa Timur. Sejak Sabtu pekan lalu, Pemerintah Kabupaten Kediri membuka obyek wisata Kelud meskipun masih dalam radius terbatas 3 kilometer dari kawah.
SURABAYA, KOMPAS.com - Sengketa batas wilayah Gunung Kelud antara Pemerintah Kabupaten Kediri dan Kabupaten Blitar Jawa Timur belum juga menemukan titik temu. Kedua daerah kini menunggu keputusan Menteri Dalam Negeri, yang berhak menentukan batas kewilayahan.

Hal itu setelah Pengadilan Tinggi Tata Usaha Negara (PT TUN) Surabaya beberapa waktu lalu telah menerima upaya banding atas putusan Pengadilan Tata Usaha Negara (PTUN) Surabaya yang memenangkan Pemkab Kediri.

Pemkab Kediri menggugat SK Gubernur Jatim Nomor 188/828/KPTS/013/2014 tentang Pencabutan Atas Keputusan Gubernur Jatim Nomor 188/113/KPTS/013/2012 tentang Penyelesaian Perselisihan Batas Daerah antara Kabupaten Blitar dengan Kabupaten Kediri yang terletak di wilayah Gunung Kelud.

"Karena banding diterima, maka gugatan Pemkab Kediri di tolak, dan mengembalikan status Gunung Kelud berdasarkan SK Gubernur Jatim. SK tersebut menyerahkan wewenang penentuan batas wilayah Gunung Kelud ke Mendagri," kata Kata Kepala Biro Administrasi Pemerintahan Umum, Pemprov Jatim, Supriyanto, Selasa (17/5/2016).

Kompas, 17 Mei 2016

Penulis : Defri Werdiono

Berdasarkan uraian diatas, jawablah beberapa pertanyaan berikut:

1. Deksripsikan pandangan Saudara, apakah faktor penyebab dari terjadinya konflik berkepanjangan antara Pemda Kediri dengan Pemda Blitar untuk memperebutkan Gunung Kelud?

2. Deskripsikan pandangan Saudara, langkah-langkah apa sajakah yang seharusnya dilakukan oleh Pemerintah Pusat untuk menyelesaikan konflik tersebut?

3. Menurut pendapat anda, apa saja dampak positif dan negatif dari penyelenggaraan pemerintahan desentralisasi di Indonesia berdasarkan case yang dibahas diatas!

\section{E. Simpulan}


Asas penyelenggaran yang berlaku di pemerintah daerah adalah asas desentralisasi, dekonsentrasi, dan tugas pembantuan. Secara umum dalam mempelajari asas desentralisasi, akan memperkenalkan dengan teori utamanya yaitu teori demokrasi liberal, teori pilihan publik dan teori marxist. Teori demokrasi leberal lahir untuk mendukung desentralisasi yang memberikan kontribusi positif bagi perkembangan penyelenggaraan di Indonesia. Manfaat adanya teori demokrasi liberal dalam asas desentralisasi adalah pemrintah daerah sebagai subjek yang mengedapankan akuntabilitas dalam penyelenggaraan sistem pemerintahannya, bertanggung jawab dalam setiap keputusan dan lain sebagainya. Hal tersebut dianggap sebagai nilai yang positif dalam penrapan teori desentralisasi di pemereintah daerah.

Teori lainnya yang diperkenalkan dalam asas ini adalah teori pilihan publik. Teori ini dapat digambarkan dengan keadaan pemerintah daerah yangdapat menentukan pilihannya berdasarkan alternatif yang diukur sejauh mana manfaat yang diberikan untuk masyarakat. Sehingga alternatif atau kebijakan yang diambil dapat berdampak besar bagi masyarakat di daerah. Sedangkan teori marxist berbeda dengan teori demokrasi liberal, teori ini beranggapan bahwa desentralisasi sebagai objek yang tidak akan mampu memnciptakan suasana demokrasi di daerah. Berdasarkan asas penyelenggaraan tersebut lahirlah beberapa perdebatan dari para ahli mengenai desentralisasi.

\section{F. Daftar Pustaka}

Chalid, P. (2005). Otonomi Daerah : Masalah, Pemberdayaan dan Konflik. Jakarta: Kemitraan. 
Cheema, G. S., \& Rondinelli, D. A. (1992). Decentralization and Development, Policy Implementation in Developing Countries. London/New Dehli: Sage Publication/Baverly Hills.

Cohen, J. M., \& Peterson, S. B. (1999). Administrative Desentralization. USA: Kumarian Perss.

Haris, S. (2007). Desentralisasi dan Otonomi Daerah : Desentralisasi, Demokrasi, dan Akuntabilitas Pemerintah Daerah. Jakarta: LIPI Press. Imawan, R. (2004). Desentralisasi, Demokratisasi, dan Pembentukan Good Governance. Jakarta: LIPI Press.

Koesoemahatmadja, R. (1979). Pengantar Kearah Sistem Pemerintahan Daerah Di Indonesia. Bandung: Bina Cipta.

Lapera, T. (2001). Otonomi Pemberian Negara, Kajian Kritis Atas Kebijakan Otonomi Daerah. Jakarta: Lapera Pustaka Utama.

Mawhood, P. (1983). Local Government in The Third World. Chicester, UK: John Wisley and Sons.

Muluk, M. R. (2006). Desentralisasi dan Pemerintah Daerah . Jakarta: Bayumedia.

Muluk, K. M.R. (2007). Menggugat partisipasi publik dalam pemerintahan daerah. Malang: Bayumedia Publishing.

Muslimin, A. (1986). Aspek-Aspek Hukum Otonomi Daerah. Bandung: Alumni.

Rodinelli. (1983). Implementing Decentralization Programmes In Asia : A Comparative Analysis. Public Administration and Development, Vol. 3.

Rondinelli, Nellis, \& Cheema. (1983). Decentralization in Developing Countries : A Review of Recent Experience. Washington: The World Bank.

Said. (2005). Arah Baru Otonomi Daerah di Indonesia. Malang: UMM. 
Seymour, \& Truner. (2002). Otonomi Daerah : Indonesia's Decetralisation Experiment. New Zealand Journal of Asian Studies 4, Vol. 2.

Slater. (1990). Debating Decentralisation - A Reply to Rondinelli. Development and Change Vol. 21.

Surianingrat, B. (1981). Desentralisasi dan Dekonsentrasi Pemerintah di Indonesia, Suatu Analisa. Jakarta: Dewaruci Perss.

Utrecht, E. (1966). Pengantar dalam Hukum Indonesia. Jakarta: Ichtiar.

\section{BAB III}

\section{ORGANISASI PEMERINTAH DAERAH}

\section{A. Deskripsi Singkat}

Indonesia sebagai negara kesatuan yang berbentuk republik terbagi atas 34 (tiga puluh empat) provinsi yang telah memiliki kewenangan penuh dalam menyelenggarakan pemerintahannya berdasarkan undang-undang tentang pemerintahan daerah yang berlaku. Sehingga dalam pelaksanaannya dibutuhkan sebuah organisasi pemerintah daerah. 
Undang-Undang Nomor 32 Tahun 2004 membuat desentralisasi berjalan menjadi lebih lebih ketat. Kewenangan yang sebelumnya diberikan kepada daerah sangat luas, pelan-pelan mulai di tarik kembali ke pusat. Melalui Peraturan Pemerintah Nomor 38 Tahun 2007 tentang Pembagian Urusan Pemerintahan Antara Pemerintah, Pemerintah Daerah Provinsi, dan Pemerintahan Daerah Kabupaten/Kota kewenangan yang telah diatur lebih detail dan lengkap agar dapat menjelaskan kegiatan dan urusan apa yang manjdi kewenangan pemerintah pusat dan urusan apa yang menjadi kewenangan pemerintah provinsi.

Pemerintah pusat mengeluarkan peraturan yang sangat ketat dalam pembentukan organisasi perangkat daerah, mulai dari besaran organisasi sampai dengan jumlah Satuan Kerja Perangkat Daerah yang boleh didirikan bagi suatu daerah tertentu menurut syaratsyarat yang telah ditentukan.

Pada Bab 3 ini mempelajari tentang organisasi pemerintah daerah yang dibentuk berdasarkan kriteria dan sasaran pemerintah daerah. Pembentukan organisasi perangkat daerah juga memperhatikan kepegawaian, rekrutmen, serta pembinaan dan pengembagan pegawai.

\section{B. Kompetensi Dasar}

Mahasiswa mampu memahami dan mendeskripsikan organisasi pemerintah daerah.

\section{Indikator}

1. Mahasiswa mampu mengetahui dan mengidentifikasi pembentukan daerah dan kriterianya.

2. Mahasiswa mampu mengetahui dan mengidentifikasi bentuk dan sasaran pemerintah daerah.

3. Mahasiswa mampu mengetahui dan mengidentifikasi kepegawaian pemerintah daerah. 
4. Mahasiswa mampu mengetahui dan mengidentifikasi rekrutmen pegawai daerah.

5. Mahasiswa mampu mengetahui dan mengidentifikasi pembinaan dan pengembangan pegawai daerah.

\subsection{Pembentukan Daerah dan Kriterianya}

Indonesia terdiri dari 34 provinsi yang telah memiliki kewenangan penuh dalam menyelenggarakan pemerintahannya berdasarkan undang-undang tentang pemerintahan daerah yang berlaku. Sehingga dalam pelaksanaannya dibutuhkan sebuah organisasi pemerintah daerah. Pembahasan dalam bab III ini akan dibahas lebih mendalam tentang administrasi pemerintah daerah. Pada pembahasan awal, akan diawali dengan pembahasan tentang pemahaman makna dari keadministrasian pemerintahan daerah.

Administrasi pemerintah daerah terbentuk dari 3 (tiga) suku kata yaitu administrasi, pemerintah dan daerah. Dalam arti sempit, administrasi ialah kegiatan yang bersifat tulis menulis mengenai segala sesuatu dalam organisasi, sehingga kegiatan yang dimaksud tidak lebih dari kegiatan tata usaha. Kegiatan yang dimaksud diantaranya pencatatan surat keluar dan masuk; pengetikan, pengiriman surat; penyimpanan arsip dan pada proses pelayanan yang lainnya.

Sedangkan, administrasi dalam arti luas ialah kegiatan yang dilakukan untuk mencapai tujuan. Kegiatan-kegiatan ini meliputi kegiatan yang direncanakan, diorganisasikan, dilaksanakan, dan dilakukan pengawasan. Dalam pengertian luas tersebut, pengertian dari tata usaha terkandung didalamnya. Administrasi yang dimaksud mengacu pada badan-badan pemerintah dan juga badan-badan swasta.

Pada hakekatnya administrasi pemerintah ialah administrasi negara dalam artian sempit. Administrasi negara dalam artian luas yang menjadi obyeknya adalah negara secara lengkap dengan badan- 
badan negara yang ada didalamnya diantaranya legislatif, eksekutif, maupun yudikatif. Sedangkan dalam artian sempit obyeknya adalah pemerintah sebagai badan eksekutif (pelaksana undang-undang). Administrasi pemerintah berhubungan dengan kegiatan-kegiatan pemerintahan yang dapat digolongkan ke dalam tiga fungsi, yaitu merumuskan atau memformulasikan kebijakan, melaksanakan tugas administrasi, dan menggunakan dinamika administrasi.

Berdasarkan Amandemen pasal 18 Undang-Undang Dasar 1945 menjelaskan bahwa Pemerintah Daerah Provinsi, Daerah Kabupaten, dan Daerah Kota mengatur dan mengurus sendiri urusan pemerintahan menurut asas otonomi dan tugas pembantuan. Asas penyelenggaraan pemerintahan di daerah yang pernah dijalankan di Indonesia secara tersurat adalah desentralisasi, dekonsentrasi, dan tugas pembantuan. Sedangkan yang tersirat adalah Vrijbestuur (Tanjung Tantra).

Sistem pemerintahan daerah merupakan suatu keseluruhan yang utuh yang di dalamnya terdapat unsur-unsur unit daerah yang mempunyai fungsi dan tugas yang saling terkait berdasarkan asas penyelenggaraan pemerintahan di daerah untuk mencapai tujuan daerah. Secara formal pemerintah daerah memiliki kewenangan daerah yang sering disebut otonomi daerah, yang diartikan sebagai hak wewenang dan kewajiban daerah untuk mengatur dan mengurus rumah tangganya sendiri sesuai dengan Peraturan Perundangan yang berlaku.

Otonomi dapat dibedakan menjadi otonomi materiil, formil, dan riil. Pemerintah pusat menyerahkan sekitar 11 bidang kewenangan pemerintahan yang wajib dilaksanakan sebagai realisasi asas desentralisasi kepada daerah. Selanjutnya pemerintah mengeluarkan Peraturan Pemerintah (PP) Republik Indonesia (RI) Nomor 25 Tahun 2000 tentang kewenangan pemerintah dan kewenangan provinsi sebagai daerah otonom guna meningkatkan penyelenggaraan 
otonomi daerah. Peraturan tersebut dibuat memberikan kejelasan dan ketegasan batas-batas kewenangan antara pemerintah pusat dan pemerintah provinsi sebagai daerah otonom, karena penyelenggaraan kegiatan ekonomi hanya diperkenankan sebatas yang ditetapkan.

Menurut Undang-undang Nomor 22 Tahun 1999 tentang Pemerintahan Daerah, dalam rangka melaksanakan asas desentralisasi maka dibentuklah dan disusunlah Daerah Provinsi, Daerah Kabupaten dan Daerah Kota yang berwenang dalam pengaturan dan pengurusan kepentingan masyarakat setempat menurut prakarsa sendiri berdasarkan aspirasi dan partisipasi masyarakat. Pembentukan daerah akan dilakukan berdasarkan pada pertimbangan-pertimbangan kemampuan ekonomi, potensi daerah, sosial-budaya, sosial-politik, jumlah penduduk, luas daerah, dan pertimbangan-pertimbangan lain yang memungkinkan terselenggaranya Otonomi Daerah.

Syarat-syarat pembentukan Daerah, dan kriteria pemekaran Daerah, penghapusan dan penggabungan Daerah ditetapkan dengan Peraturan Pemerintah, yang dalam hal ini Peraturan Pemerintah (PP) Nomor 129 Tahun 2000 membahas tentang persyaratan pembentukan dan kriteria pemekaran, penghapusan dan penggabungan Daerah.

\subsection{Bentuk dan Sasaran Pemerintah Daerah}

Secara umum terdapat dua bentuk pemerintahan daerah di dunia ini menurut Djaenuri (2014), yaitu Local Self Government dan Local State Government.

1. Local Self Government

Pemerintah daerah dalam bentuk Local Self Government berwenang mengatur dan mengurus pemerintahan sendiri. Pemerintahan 
daerah dalam bentuk Local Self Government ini diperlukan oleh sistem pemerintahan negara untuk menyelenggarakan berbagai urusan pemerintahan yang sesuai dengan kondisi daerah. Artinya, dalam hal-hal tertentu penyelenggaraan pemerintahan negara di daerah akan lebih efisien dan efektif jika diserahkan kepada pemerintahan daerah tertentu. Hal ini dikarenakan pemerintah daerah lebih memahami kebutuhan daerah dan kondisi masyarakat setempat. Demikian juga untuk menyelenggarakan pemerintahan di daerah-daerah khusus tertentu, perlu dibentuk pemerintahan yang mempunyai kewenangan untuk mengatur dan mengurus urusan pemerintahan yang ada di daerah tersebut. Walaupun pemerintahan daerah dalam bentuk Local Self Government memiliki kewenangan untuk mengatur dan mengurus urusan pemerintahan yang menjadi urusan rumah tangganya akan tetapi kedudukannya tetap merupakan subsistem dari sistem pemerintahan Negara.

Bentuk pemerintahan daerah Local Self Government merupakan akibat dari asas desentralisasi dalam penyelenggaraan pemerintahan negara. Pemerintahan daerah dibentuk berdasarkan undang-undang dan diberi kewenangan untuk mengurus urusan pemerintahan tertentu. Undang-undang telah mengatur bahwa daerah dapat dimekarkan menjadi beberapa daerah tertentu, dan juga dapat digabungkan dengan daerah lain atau dapat dihapuskan jika daerah tersebut dipandang tidak mampu mengurus urusan pemerintahan yang menjadi urusan rumah tangganya. Local Self Government dibutuhkan untuk merespon tuntutan kebutuhan masyarakat di daerah yang tidak mungkin diurus secara terpusat oleh pemerintah pusat. Penanganan urusan pemerintahan ini akan lebih baik jika ditangani oleh pemerintahan daerah tertentu (Local Self Government). Dalam sistem pemerintahan Negara Indonesia, Local Self Government adalah pemerintahan daerah otonom sebagai 
pemerintah daerah yang mempunyai hak dan wewenang untuk mengatur dan mengurus rumah tangga daerahnya sendiri.

Menurut Djaenuri (2014) terdapat ciri-ciri tertentu Local Self Government atau pemerintahan daerah otonom yaitu sebagai berikut :

a. Semua urusan harus dijelaskan secara rinci karena urusan-urusan yang dijalankan sudah menjadi urusan rumah tangga sendiri.

b. Penyelenggara pemerintahan daerah dilaksanakan sendiri oleh pegawai pemerintah daerah, bukan pejabat pemerintah pusat.

c. Penanganan di berbagai urusan seluruhnya dilaksanakan sendiri berdasarkan kebijaksanaan atau inisiatifnya.

d. Keterikatan yang mengatur suatu hubungan dalam segi pengawasan yang dilakukan oleh pihak pemrintah pusat dan pemrntah daerah .

e. Seluruh penyelenggaraan pemerintahan daerah pada hakekatnya adalah dibiayai berdasar pada sumber keuangan sendiri.

Oleh karen itu, Local Self Government atau pemerintahn lokal percaya bahwa konsep ini merupakan langkah daerah agar mampu mengatur serta mengurus apa yang dibutuhkan dalam daerahnya untuk memenuhi konsep otonomi daerah. Selain itu pemberian kewenangan yang merupakan hak dari lahirnya otonomi daerah menjadi bagian yang tidak dapat dipisahkan dari adanya sistem kepemerintahan negara.

\section{Local State Government}

Local state government merupakan bagian atas dasar asas dekonsentrasi yang terjadi di lingkungan pemerintah daerah. Local state Government menjadikan kewenangan secara adminsitratif yang 
sebelumnya berada di tangan atau berada di kekuasaan pemerintah pusat, kini berpindah menjadi kewenangan daerah itu sendiri. Hal itu karena tidak semua urusan dapat berjalan dengan efisien dan efektif apabila ditangani secara langsung oleh pemerintah pusat. Oleh karena itu, pemerintahan daerah dibentuk dengan tujuan untuk menyelenggarakan urusan pemerintahan tertentu yang menjadi kewenangan pemerintah pusat di daerah. Local state government atau pemerintahan daerah bertugas hanya untuk menyelenggarakan instruksi-instruksi, arahan, petunjuk-petunjuk dan kebijakankebijakan pemerintah pusat.

Pemerintahan wilayah dibutuhkan karena wilayah negara sangat luas, sedangkan tugas-tugas pemerintah pusat sangat banyak dan terkendala komunikasi yang tidak lancar. Hal itu menghambat jalannya komunikasi langsung antara pemerintah dan masyarakat. Komunikasi sosial merupakan suatu hal yang sama pentingnya dengan komunikasi fisik. Seberapa intens hubungan tatap muka antara pejabat pemerintah pemberi pelayanan dengan masyarakat menentukan banyaknya pelayanan yang diberikan. Komunikasi secara langsung bertujuan untuk menjelaskan kebijakan pemerintah dan memperoleh respon dari anggota masyarakat secara langsung. Pemerintahan wilayah berperan penting untuk memaksimalkan kepatuhan masyarakat terhadap program pemerintah. Tugas pemerintahan wilayah hanya sebatas pada pelaksanaan tugas yang diberikan oleh pemerintah pusat.

Menurut Djenuri (2014) menjelaskan yang dapat dikatakan sebagai pemerintah wilayah atau pemerintah administratif memiliki beberapa ciri-ciri diantaranya:

a. Melimpahkan kekuasaan menjadi suatu bentuk dalam pemberian kewenangan kepada pihak lainnya. 
b. Daerah menjadi tujuan pemerintah pusat dalm pemberian kekuasaan yang dimiliki pemerintah pusat sebelumnya.

c. Tidak semua kebijakan mampu ditangani oleh pemerintah pusat menjadi alasan terpenting pelimpahan ini sehingga kebijakan tidak akan tepat sasaran jika tidak dilimpahkan kepada daerah. Kondisi tersebut dapat diartikan bahwa terbatasnya kemampuan pemerintah pusat dalam mengelola dan menjangkau semua wilayah.

d. Kewenangan yang diberikan untuk mengatasi persoalan sebelumnya yang terjadi yaitu keterbatasan yang dimiliki oleh pemerintah wilayah dalam mengelola dan mengatur daerahnya sendiri.

Unsur utama dalam penyelenggaraan pemerintahan di daerah dan salah satu subsistem dari sistem Pemerintah Indonesia adalah pemerintah daerah. Oleh karena itu, pemerintah pusat dan daerah sama-sama memiliki tujuan untuk mewujudkan cita-cita nasional sebagaimana dirumuskan dalam Pembukaan UUD 1945. Terdapat pembagian wewenang dan tanggung jawab antara Pemerintah Pusat dan Pemerintah Daerah dalam penyelenggaraan pemerintahan jika dilihat dari aspek manajemen. Akan tetapi, pemerintah pusat tetap memegang tanggung jawab terakhir. Apabila diperhatikan secara mendalam, pertimbangan-pertimbangan tentang perlunya penyerahan kewenangan kepada Pemerintah Daerah memuat maksud dan tujuan berikut :

1. Secara politis untuk memberi peluang kepada masyarakat untuk ikut serta dalam mekanisme penyelenggaraan pamerintahan dan tetap menjaga keutuhan Negara Kesatuan Republik Indonesia berdasarkan Pancasila dan UUD 1945 yang dikonstruksikan dalam sistem Pemerintahan Pusat dan Daerah. 
2. Secara formal dan konstitusional untuk melaksanakan ketentuan dan amanat UUD 1945.

3. Secara operasional untuk meningkatkan pelayanan masyarakat, melancarkan pelaksanaan pembangunan, meningkatkan efisiensi dan efektivitas penyelenggaraan pemerintahan.

4. Secara administrasi pemerintahan untuk meningkatkan dan mendisiplinkan pelaksanaan tata pemerintahan yang lebih baik guna mencapai rangka good governance.

Oleh karena itu dalam setiap kegiatan Pemerintahan Daerah harus mengarahkan kepada pertumbuhan pembangunan daerah, terselenggaranya pembinaan kestabilan politik dan kesatuan bangsa, serta terjaminnya hubungan yang harmonis antara Pemerintah Pusat dan Daerah atas dasar keutuhan Negara Kesatuan untuk mencapai tujuan otonomi daerah.

Berdasar pada Undang-Undang Nomor 32 Tahun 2004 tujuan pemberian otonomi kepada daerah diarahkan untuk :

1. Peningkatan pada pelayanan, pemberdayaan, dan peran serta masyarakat untuk mewujudkan kesejahteraan.

2. Peningkatan daya saing daerah dengan prinsip-prinsip demokrasi, keadilan, pemerataan, keistimewaan, dan kekhususan, serta potensi dan keanekaragaman daerah dalam sistem Negara Kesatuan Republik Indonesia.

3. Memperhatikan potensi dan keanekaragaman daerah, menguatkan hubungan antar susunan pemerintahan dan antar pemerintah daerah guna peningkatan pada efektivitas dan efisiensi penyelenggaraan pemerintahan daerah.

4. Aspek hubungan wewenang perlu memperhatikan kekhususan dan keragaman daerah dalam sistem Negara Kesatuan Republik Indonesia. 
5. Aspek pada hubungan keuangan, pelayanan umum, pemanfaatan sumber daya alam dan sumber daya lainnya harus dilaksanakan secara adil dan selaras.

6. Pemanfaatan pada perkembangan ilmu pengetahuan dan teknologi sebagai basic/dasar dalam menghadapi peluang dan tantangan dalam persaingan global.

7. Pemberian kewenangan yang seluas-luasnya kepada daerah, yang disertai dengan pemberian hak dan kewajiban penyelenggaraan otonomi daerah dalam kesatuan sistem penyelenggaraan pemerintahan negara.

Dengan demikian dapat dikemukakan bahwa tujuan pemberian otonomi kepada daerah itu menurut Undang-Undang Nomor 32 tahun 2004 adalah :

1. Memberikan kewenangan seluas-luasnya kepada daerah.

2. Meningkatkan kesejahteraan masyarakat.

3. Meningkatkan efisiensi dan efektivitas pelaksanaan/penyelenggaraan pemerintahan daerah.

4. Meningkatkan daya saing daerah. Menurut Kaho (1988) dalam Djaenuri (2014), maksud dan tujuan otonomi daerah daerah adalah :

1. Efisiensi dan efektivitas pelaksanaan/penyelenggaraan pemerintahan daerah.

2. Melibatkan masyarakat daerah sebagai bentuk demokrasi dalam penyelenggaraan pemerintahan daerah.

Organisasi Pemerintahan Daerah terdiri dari Pemerintah Daerah dan DPRD. Masing-masing lembaga tersebut berdiri sendiri, namun berkedudukan sejajar dan bermitra. Pemerintah Daerah merupakan lembaga eksekutif yang dibentuk untuk melaksanakan desentralisasi di daerah. Sedangkan DPRD sebagai badan legislatif daerah yang berfungsi sebagai sarana pelaksanaan demokrasi di daerah. 
Pemerintah Daerah tersusun atas Kepala Daerah dan Perangkat Daerah. Perangkat Daerah beranggotakan Sekretariat Daerah, Dinas Daerah, dan Lembaga Teknis lainnya sesuai dengan kebutuhan Daerah. Susunan Organisasi Perangkat Daerah ditetapkan melalui Peraturan Daerah (PERDA) dan berpedoman pada Peraturan Pemerintah. Sekretaris Daerah bertugas untuk membantu Kepala Daerah dalam menyusun kebijakan dan membina hubungan kerja dengan Dinas, Lembaga Teknis, dan unit pelaksana lainnya. Dinas Daerah adalah unsur pelaksana Pemerintah Daerah dan Lembaga Teknis Daerah mempunyai tugas membantu Kepala Daerah dalam penyelenggaraan Pemerintahan Daerah di bidangnya.

\subsection{Kepegawaian Pemerintah Daerah}

Pada masa ini pemerintah mulai memperhatikan perlunya pemusatan urusan kepegawaian di Indonesia yang sebelumnya telah dilaksanakan oleh KUP di Yogyakarta dan DUUP di Jakarta. Kedua lembaga tersebut akhirnya dilebur menjadi satu bernama KUP berdasarkan Peraturan Pemerintah Nomor 32 Tahun 1950 dan berkedudukan di Jakarta. Selanjutnya Peraturan Pemerintah Nomor 11 Tahun 1948 mengatur tentang tugas pokok KUP yaitu mengurus kedudukan dan gaji Pegawai Negeri serta mengawasi pelaksanaan peraturan kepegawaian agar dijalankan dengan tepat. Dalam perjalanannya ternyata KUP tidak menunjukkan fungsinya secara maksimal karena administrasi kepegawaian pada waktu itu belum teratur. Pembinaan administrasi kepegawaian tidak dapat dilakukan dengan baik karena kurangnya tenaga ahli, sulitnya komunikasi, dan sulitnya menyimpan arsip. Dapat dikatakan KUP tidak berfungsi dengan maksimal dan eksistensinya tidak dirasakan oleh pegawai negeri.

Selanjutnya Peraturan Pemerintah Nomor 32 Tahun 1972 disahkan untuk meningkatkan fungsi KUP, dan KUP berubah nama menjadi 
Badan Administrasi Kepegawaian Negara. BAKN merupakan Lembaga Pemerintah Nondepartemen yang berkedudukan langsung dan bertanggung jawab kepada Presiden. Fungsi BAKN diatur dalam Keputusan Presiden Nomor 15 Tahun 1988, dan terakhir diatur dalam Keputusan Presiden Nomor 143 Tahun 1998. Kemudian dalam Keputusan Presiden Nomor 95 Tahun 1999 tentang Badan Kepegawaian Negara dijelaskan bahwa Presiden mengatur kembali kedudukan, tugas pokok, fungsi, dan organisai BAKN dengan mengubah nama BAKN menjadi Badan Kepegawaian Negara (BKN), yang diharapkan dapat mengoptimalkan fungsi dan eksistensinya dalam meningkatkan sumber daya manusia pegawai negeri sipil.

Dalam perjalanannya, Keputusan Presiden Nomor 95 Tahun 1999 diganti dengan Keputusan Presiden Nomor 166 Tahun 2000 yang juga mengalami beberapa kali perubahan. Kemudian diganti lagi dengan Keputusan Presiden Nomor 103 Tahun 2001. Perubahan UndangUndang Nomor 8 Tahun 1974 tentang Pokok- Pokok Kepegawaian dengan Undang-Undang Nomor 43 Tahun 1999 bertujuan untuk membentuk Badan Kepegawaian Negara menjadi lebih tegas dalam mempertahankan fungsi dan eksistensinya. Badan Kepegawaian Negara dibentuk melalui pedoman Pasal 34 ayat (1) yang menjelaskan bahwa Badan Kepegawaian Negara dibentuk untuk menjamin kelancaran penyelenggaraan manajemen PNS. Selanjutnya dalam ayat (2) dijelaskan bahwa Badan Kepegawaian Negara melaksanakan manajemen Pegawai Negeri Sipil mulai dari perencanaan, pengembangan SDM, administrasi pegawai, memelihara informasi kepegawaian, mendukung perumusan kebijakan kesejahteraan PNS, bimbingan teknis terhadap unit organisasi yang menangani kepegawaian di pemerintah pusat dan pemerintah daerah, serta melakukan pengawasan dan pengendalian. 
Pasal 34A ayat (1) menjelaskan lebih lanjut tentang pembentukan Badan Kepegawaian Daerah (BKD) untuk kelancaran pelaksanaan administrasi kepegawaian di daerah. BKD merupakan perangkat daerah otonom yang dibentuk oleh kepala daerah yang bertugas membantu pejabat pembina kepegawaian daerah dalam menjalankan manajemen PNS di daerah dan bertanggungjawab kepada kepala daerah melalui sekretaris daerah. Badan Kepegawaian Derah mempunyai tugas pokok membantu pejabat pembina kepegawaian daerah dalam menjalankan manajemen PNS daerah, dan bertanggung jawab kepada kepala daerah melalui Sekretaris Daerah. Selanjutnya Keputusan Presiden Nomor 159 Tahun 2000 tentang Pedoman Pembentukan Badan Kepegawaian Daerah menjelaskan bahwa daerah otonom yang belum membentuk Badan Kepegawaian Daerah (BKD), manajemen administrasi kepegawaian daerahnya dilakukan oleh badan atau unit pengelolaan kepegawaian daerah dengan bantuan Kantor Regional Badan Kepegawaian Negara yang bersangkutan.

Pasal 4 ayat (1) UUD 1945 menjelaskan bahwa Presiden sesuai kedudukan dan fungsinya berwenang membentuk Badan Kepegawaian Negara selama ia memegang dan menyelenggarakan pemerintahan. Dalam rangka untuk memperlancar pelaksanaan tugas-tugas pemerintahan, Presiden berwenang membentuk satuansatuan pelaksana pemerintahan diluar departemen. Otonomi daerah bertujuan untuk memberi kebebasan dan kemandirian kepada daerah dalam mengatur dan mengurus rumah tangganya sendiri. Selain itu juga untuk meningkatkan efesiensi dan efektivitas pelayanan terhadap masyarakat dalam penyelenggaraan pemerintahan di daerah. Pegawai-pegawai yang ada daerah sangat menentukan bagi keberhasilan pencapaian tujuan otonomi daerah. Perbedaan antara Pegawai Negeri Sipil (PNS) pusat dengan Pegawai Negeri Sipil (PNS) daerah di dalam struktur kepegawaian 
menunjukkan adanya asas desentralisasi dan dekonsentrasi. Asas desentralisasi memungkinkan daerah untuk bebas dan mandiri dalam menentukan dan mengatur sendiri administrasi kepegawaian daerahnya. Desentralisasi urusan kepegawaian daerah merupakan pelengkap bagi pelaksanaan Undang-Undang Nomor 22 Tahun 1999. Desentralisasai kepegawaian diwujudkan dengan pemberiaan kewenangan kepada daerah untuk mengatur administrasi kepegawaiannya melalui peraturan daerah dan keputusan kepala daerah (Siagian, 1996).

Kewenangan tersebut diatur dalam Pasal 76 Undang-Undang Nomor 22 Tahun 1999 yang menjelaskan bahwa daerah mempunyai kewenangan untuk melakukan pengangkatan, pendidikan dan pelatihan, gaji, tunjangan dan kesejahteraan pegawai, pemindahan, pemberhentian, dan penetapan pensiun sesuai dengan kebutuhan dan kemampuan daerah yang ditetapkan dengan peraturan daerah, berdasarkan peraturan perundang-undangan.

Kewenangan tersebut juga berpedoman pada Keputusan Presiden Nomor 159 Tahun 2000 tentang Pedoman Pembentukan Badan Kepegawaian Daerah yang menjelaskan tentang kewenangan delegasi oleh Presiden kepada perangkat daerah. Pada pasal 1 angka 1 dijelaskan bahwa Badan Kepegawaian Daerah sebagai perangkat daerah bertugas menjalankan administrasi kepegawaian daerah dalam membantu tugas pokok Pejabat Pembina Kepegawaian Daerah. Selanjutnya pasal 5 ayat (2) menjelaskan bahwa pembentukan Badan Kepegawaian Daerah ditetapkan dengan Peraturan Daerah. Berdasarkan asas dan peraturan tersebut, peluang pemerintah pusat untuk melakukan intervensi/ikut campur tangan dalam mengatur penyelenggaran administrasi kepegawaian daerah sangatlah kecil. Kegiatan yang dapat dilakukan oleh Badan Kepegawaian Negara hanyalah sebatas mengelola sistem keadministrasian pegawai daerah saja yaitu perihal penentuan 
kebijakan mengenai aturan, standart operasional dan prosedur secara global atau nasional yang dilakukan melalui kerjasama dengan Komisi Kepegawaian Negara. Kondisi tersebutpun menjadikan peluang yang dimiliki Badan kepegawaian Negara sangatlah kecil jika dibandingkan dengan realita bahwa BKN adalah lembaga yang berasal dari pemerintah pusat. Hal tersebut juga menjadikan Badan Kepegawaian Negara tidak mempunyai wewenang selain hal yang telah dijelaskan sebelumnya kepada kepegawaian daerah.

Berlakunya Undang-Undang Nomor 32 Tahun 2004 tentang Pemerintahan Daerah telah menggantikan Undang-Undang Nomor 22 Tahun 1999. Pengaturan mengenai administrasi kepegawaian daerah berubah lagi dengan adanya peluang bagi pemerintah pusat untuk mengatur administrasi kepegawaian daerah. Hal ini seperti diatur dalam Pasal 29 ayat (1) UU No.32/2004 yang menyatakan bahwa pemerintah melaksanakan pembinaan manajemen PNS daerah dalam satu kesatuan penyelenggaraan manajemen PNS secara nasional.

Demikian juga dengan Pasal 131 ayat (1), (2), dan (3) yang mengatur bahwa perpindahan PNS daerah harus melalui pertimbangan dari Badan Kepegawaian Negara. Pasal 132 mengatur penetapan formasi PNS daerah tiap tahuan anggaran dilaksakan oleh Menteri Pendayagunaan Aparatur Negara atau usul Gubernur. Serta pasal 135 mengatur pembinaan serta pengawasan manajemen PNS daerah dikoordinasikan pada tingkat nasional oleh Menteri Dalam Negeri dan pada tingkat daerah oleh Gubernur.

\subsection{Rekrutmen Pegawai Daerah}

Formasi adalah penentuan jumlah dan susunan pangkat Pegawai Negeri Sipil yang diperlukan agar mampu melaksanakan tugas pokok yang ditetapkan oleh pejabat yang berwenang. Di Dalam suatu 
organisasi selalu terbuka kemungkinang untuk terjadinya lowongan. dengan aneka penyebabnya oleh karena itu lowongan yang kosong harus segera di isi. Proses kegiatan untuk mengisi formasi yang lowong adalah dengan pengadaan. Kegiatan pengadaan yang dilakukan harus denga perencanaan yang matang sehingga pada saat proses pengadaan berlangsung dapat mencapai jumlah recruits sesuai dengan persyaratan untuk keperluan seleksi selanjutnya. Menurut Hasibuan (2000) Rekrutmen adalah usaha mempengaruhi tenaga kerja agar mau melamar lowongan pekerjaan yang ada dalam suatu pekerjaan. Menurut Rachmawati (2008) Rekrutmen adalah proses mencari menemukan dan menarik para calon Pegawai untuk di pekerjakan Oleh organisasi. Sedangkan menurut Simamora (2004) menyatakan bahwa proses rekrutmen pada dasarnya menerapkan beberapa hal :

1. Pengindentifikasian kebutuhan untuk melakukan pengadaan;

2. Membuat deskripsi, spesifikasi, dan standar kinerja yang rinci;

3. Menentukan sumber-sumber kandidat ;

4. Menentukan kriteria-kriteria rekrutmen;

5. Menyeleksi sumber-sumber rekrutmen;

6. Menyusun dan menyeleksi dan menjadwalkan program rekrutmen;

7. Memberitahukan hasil kepada para pelamar;

8. Menunjuk kandidat yang lolos seleksi.

Pengelolaan kepegawaian di Indonesia, pada dasarnya telah mengalami pasang surut pengaturan baik pada masa orde baru hingga era reformasi yang menempatkan peranan otonomi daerah sebagai salah satu solusi percepatan pertumbuhan pembangunan melalui pengelolaan kepegawaian dengan peningkatan sumber daya manusia di daerah. Pada masa pemerintahan orde baru tatanan 
birokrasi pemerintahan sangat dipengaruhi oleh peranan sentralistis dan otoritarian dari pemerintah pusat kedaerah, ini tercermin dari kebijakan yang telah di bentuk oleh pemerintah pusat kepada daerah, khususnya yang berkaitan dengan sistem pengelolaan kepegawaian.

Sistem reformasi kepegawaian daerah membawa angin segar dalam dunia kepengelolaan kepegawaian. Hal tersebut ditandai dengan mandirinya pemerintah daerah dalam segi pengadaab pegawai. Pemerintah daerah dapat merencanakan, mengorganisir, memipin bahkan mengendalikan mengenai pengadaan pegawai daerah. Kondisi inilah yang menjadikan semakin kuatnya sistem otonomi daerah yang ada. Segala urusan dalam hal kepegawaian dilakukan oleh pemrintah daerah menjadi bentuk kesemangatan untuk memperbaiki sistem birokrasi. Mengenai hal ini pulalah yang dapat dijelaskan dalam Undang-Undang Nomor 43 Tahun 1999. Peraturan ini menggantikan peraturan yang digunakan sebelumnya yang menjelaskan aturan perihal kemapuan dan prestasi pegawai seperti yang tertera di Undang-undang no 8 tahun 1974. Selain daripada itu, momentum ini merupakan hasil dari penerapan reformasi yang ada di Indonesia yang terjadi pada tahun 1998. Sebelumnya perlu kita ketahui bahwa indonesia pernah mengalami kondisi yang tidak stabil dalam pengelolaan pegawai, sehingga dengan adanya otonomi daerah diharapkan mampu menjadi solusi dalam memberikan kekuatan pembangunan dalam segi pembangunan manusia. Yang dimaksud pembangunan manusia adalah otonomi daerah mampu memberikan dan meningkatakan kualitas Sumber Daya Manusia hingga ketingkat daerah karena pada masa orde baru peranan sentralistik lebih menojol jika dibandingkan dengan peranan desentralistik yang dapat membatasi ruang gerak pemerintah daerah. 
Proses pengelolaan manajemen diatur dalam Undang-Undang Pokok Kepegawaian yang berkaitan dengan pembinaan PNS berdasarkan pada penilaian sistem karir dan prestasi kerja. Undang-Undang Nomor 43 Tahun 1999 tentang pokok-pokok kepegawaian menjelaskan bahwa terdapat beberapa upaya peningkatan kemampuan manajemen pegawai negeri sipil yaitu fungsi dan kewajiban, profesionalisme penyelenggaraan tugas, efesiensi, dan efektivitas. Kewajiban yang dimaksud yaitu meliputi perencanaan, pengadaan, pengembangan, kualitas, penempatan, promosi, penggajian, kesejahteraan dan pemberhentian.

Kebijakan manajemen Pegawai Negeri Sipil tercantum dalam pasal 13 ayat (1) Undang-Undang tentang Pokok-Pokok Kepegawaian yang memuat tentang perencanaan, persyaratan, prosedur, norma standar, formasi, pengangkatan, penempatan, pengembangan kualitas SDM, pemindahan, gaji, tunjangan, kesejahteraan, pensiun, pemberhentian, hak, kewajiban dan kedudukan hukum. Penjelasan tersebut sesuai dengan pelaksanaan Undang-Undang Nomor 32 Tahun 2004 tentang Pemerintahan Daerah yang menjelaskan pengelolaan kepegawaian daerah sekurang-kurangnya harus memuat beberapa ketentuan yang telah diatur didalam UndangUndang Pokok Kepegawaian. Pengelolaan kepegawaian daerah merupakan satu kesatuan jaringan birokrasi dalam kepegawaian nasional. Pasal 129 ayat (1) Undang-Undang Nomor 32 Tahun 2004 tentang Pemerintahan Daerah menjelaskan bahwa pemerintah melaksanakan pembinaan manajemen pegawai negeri sipil daerah dalam satu kesatuan penyelenggaraan manajemen pegawai negeri sipil secara nasional. Ketentuan tersebut kemudian dilanjutkan kedalam Pasal 129 ayat (2) yang menjelaskan bahwa manajemen pegawai negeri sipil daerah meliputi penetapan formasi, pengadaan, pengangkatan, pemindahan, pemberhentian, penetapan pensiun, 
gaji, tunjangan, kesejahteraan, hak dan kewajiban, kedudukan hukum, pengembangan kompetensi dan pengendalian jumlah. Selanjutnya pasal 135 ayat (1) menjelaskan bahwa pembinaan dan pengawasan manajemen pegawai negeri sipil daerah dikoordinasikan dengan Menteri Dalam Negeri pada tingkat pusat, dan dengan Gubernur pada tingkat daerah.

Sistem Rekrutmen Pegawai Negeri Sipil. Sebelum melakukan rekrutmen pegawai didahului proses Formasi Pegawai Negeri Sipil (PNS). Formasi PNS ini diatur dalam Peraturan Pemerintah Nomor 54 Tahun 2003 telah ditentukan Pokok-pokok Penyusunan Formasi Pegawai Negeri Sipil untuk mengisi satuan organisasi pemerintah. Menurut Undang-undang Nomor 43 Tahun 1999 yang dimaksud formasi adalah jumlah dan susunan pangkat pegawai Negeri Sipil yang diperlukan oleh suatu satuan organisasi negara untuk mampu melaksanakan tugas pokok untuk jangka waktu tertentu yang ditetapkan oleh menteri yang bertanggung jawab dalam bidang penerbitan dan penyempurnaan Aparatur Negara. Proses Pengadaan Pegawai negeri Sipil Setelah melalui formasi PNS, maka tahapan selanjutnya adalah hasil dari formasi tersebut dijadikan dasar untuk melakukan pengadaan atau rekrutmen CPNS. Pengadaan Pegawai Negeri Sipil adalah proses kegiatan untuk mengisi formasi yang lowong. Lowongan formasi dalam formasi dalam suatu satuan organisasi Negara pada umumnya disebabkan oleh 2 (dua) yaitu, adanya Pegawai Negeri Sipil yang berhenti atau adanya perluasan organisasi. Karena pengadaan Pegawai Negeri Sipil ini adalah untuk keperluan, baik dalam arti jumlah, maupun dalam arti mutu. Kebijakan pengadaan PNS ini diatur oleh Peraturan Pemerintah Nomor 98 tahun 2000 tentang Pengadaan Pegawai Negeri sipill.

Konsep Aparatur Sipil Negara (ASN) Dalam ketentuan umum undangundang nomor 5 tahun 2014 tentang aparatur sipil Negara 
dijelaskan aparatur sipil negara yang selanjutnya disingkat ASN adalah profesi bagi pegawai negeri sipil dan pegawai pemerintah dengan perjanjian kerja yang bekerja pada instansi pemerintah. Selanjutnya di sebutkan Pegawai aparatur sipil Negara yang selanjutnya disebut pagawai ASN adalah pegawai negeri sipil dan pegawai pemerintah dengan perjanjian kerja yang di angkat oleh pejabat Pembina kepegawaian dan di serahi tugas dalam suatu jabatan pemerintahan atau di serahi tugas Negara lainnya dan di gaji berdasarkan peraturan perundang-undangan. Dalam Manajemen ASN adalah pengelolaan ASN untuk menghasilkan pegawai ASN yang professional, memiliki nilai dasar, etika profesi, bebas dari intervensi politik, bersih dari praktik korupsi, kolusi dan nepotisme. Bahwa untuk mewujudkan aparatur sipil Negara sebagai bagian dari reformasi birokrasi, perlu ditetapkan apartur sipil Negara sebagai bagian dari reformasi birokrasi, perlu ditetapkan aparatur sipil Negara sebagai profesi yang memiliki kewajiban mengelola dan mengembangkan dirinya dan wajib mempertanggungjawabkan kinerjanya dan menerapkan prinsip merit dalam pelaksanaan manajemen apartur sipil Negara.

Konsep Kinerja BKD Dalam Rekruitmen Badan Kepegawaian Daerah (BKD) merupakan badan yang dibentuk setelah pelaksanaan otonomi daerah tahun 1999. Badan ini mempunyai tugas untuk mengurusi administrasi kepegawaian pemerintah daerah baik di pemerintah daerah kabupaten/kota maupun pemerintah daerah provinsi. Hampir sebagian besar BKD ini hanya berada ditingkat kabupaten/kota sedangkan ditingkat provinsi banyak yang masih menggunakan biro yakni Biro Kepegawaian. Sesuai dengan undangundang pemerintahan daerah kewenangan mengatur kepegawaian mulai dari rekrutmen sampai dengan pensiun berada di 
kabupaten/kota (Thoha,2014). Sementara Tugas Pokok dan Fungsi Badan Kepegawaian Daerah adalah sebagi berikut :

1. Tugas Pokok

a. Melaksanakan urusan Pemerintahan Daerah dalam penyusunan dan pelaksanaan kebijakan daerah bidang Kepegawaian;

b. Melaksanakan tugas-tugas lain yang diberikan oleh Bupati sesuai dengan bidang tugasnya.

2. Fungsi

a. Pengumpulan, pengelolaan dan pengendalian data berbetuk database serta analisa data untuk penyusunan program kegiatan;

b. Perencanaan strategis pada Badan Kepegawaian Daerah;

c. Perumusan kebijakan teknis bidang kepegawaian;

d. Penyelenggaraan urusan pemerintahan dan pelayanan umum bidang kepegawaian;

e. Pembinaan dan pelaksanaan tugas bidang kepegawaian;

f. Pelaksanaan, pengawasan, pengendalian serta evaluasi dan pelaporan penyelenggaraan bidang kepegawaian;

g. Pelaksanaan standar pelayanan minimal yang wajib dilaksanakan bidang kepegawaian;

h. Penyelenggaraan urusan kesekretariatan pada Badan Kepegawaian Daerah;

i. Pengkoordinasian, integrasi dan sinkronisasi kegiatan bidang kepegawaian di lingkungan Pemerintah Daerah;

j. Pembinaan dan pelaksanaan kerjasama dengan masyarakat, Lembaga Pemerintah dan Lembaga lainnya;

k. Penyelenggaraan administrasi Pegawai Negeri Sipil Daerah; 
I. Pelaksanaan peraturan perundangundangan bidang kepegawaian;

m. Perencanaan formasi dan pengembangan kepegawaian;

n. Penyiapan kebijakan umum pengembangan kepegawaian dan berkoordinasi dengan Badan Pendidikan dan Pelatihan;

o. Penyiapan dan pelaksanaan pengangkatan, pemindahan dan pemberhentian Pegawai Negeri Sipil Daerah sesuai dengan norma standar dan prosedur yang ditetapkan dalam peraturan perundang-undangan;

p. Penyiapan dan pelaksanaan administrasi pengangkatan, pemindahan dan pemberhentian dalam dan dari jabatan struktural atau fungsional sesuai dengan norma standar dan prosedur yang ditetapkan dengan peraturan perundangundangan;

q. Penyiapan dan penetapan pensiun Pegawai Negeri Sipil Daerah;

r. Penetapan gaji, tunjangan dan kesejahteraan Pegawai Negeri Sipil Daerah sesuai dengan norma standar dan prosedur yang ditetapkan dalam peraturan perundang undangan;

s. Pelaksanaan pemberian penghargaan dan tanda jasa kepada Pegawai Negeri Sipil;

t. Penyiapan dan pelaksanaan administrasi kepangkatan Pegawai Negeri Sipil sesuai dengan norma standar dan prosedur yang ditetapkan dalam peraturan perundangundangan;

u. Pengelolaan Sistem Informasi Manajemen Kepegawaian secara komprehensif;

v. Penyiapan kebutuhan data dan/atau informasi untuk penyusunan program pengembangan kepegawaian;

w. Pendokumentasian tata naskah kepegawaian;

$x$. Penyelenggaraan pembinaan, pengawasan dan pengendalian di bidang kepegawaian. 


\subsection{Pembinaan dan Pengembangan Pegawai Daerah}

Menurut Poerwadarminta (2006), pembinaan adalah yang dilakukan secara sadar, terencana, teratur, dan terarah untuk meningkatkan pengetahuan, sikap dan keterampilan subjek dengan tindakan pengarahan dan pengawasan untuk mencapai tujuan. Selanjutnya, pembinaan menurut Miftah Thoha (2008) adalah suatu tindakan, proses, hasil, atau pernyataan menjadi lebih baik. Dalam hal ini menunjukkan adanya kemajuan, peningkatan, pertumbuhan, evolusi atas berbagai kemungkinan, berkembang atau peningkatan atas sesuatu. Ada dua unsur dari pengertian ini, yakni pembinaan itu sendiri bisa serupa suatu tindakan, proses atau pertanyaan dari suatu tujuan, dan kedua, pembinaan itu bisa menunjukkan kepada "perbaikan" atas "sesuatu".

Sedangkan pengembangan menurut Kamus Besar Bahasa Indonesia, merupakan proses, cara, perbuatan mengembangkan, sedangkan mengembangkan merupakan perintah selalu berusaha di pembangunan secara bertahap dan teratur yang menjurus pada sasaran yang dikehendaki. Sesuai dengan uraian tersebut, UndangUndang Nomor 20 tahun 2008 tentang Usaha Mikro, Kecil dan Menengah menjelaskan bahwa, pengembangan adalah upaya yang dilakukan Pemerintah, Pemerintah Daerah, Dunia Usaha dan masyarakat untuk memberdayakan Usaha Mikro, Kecil dan Menengah melalui pemberian fasilitas, bimbingan, pendampingan dan bantuan perkuatan untuk menumbuhkan dan meningkatkan kemampuan dan daya saing Usaha Mikro, Kecil dan Menengah.

Sedangkan Peraturan Pemerintah Republik Indonesia Nomor 12 Tahun 2017 Tentang Pembinaan Dan Pengawasan Penyelenggaraan Pemerintahan Daerah, Pembinaan Penyelenggaraan Pemerintahan Daerah adalah usaha, tindakan, dan kegiatan yang ditujukan untuk 
mewujudkan tercapainya tujuan penyelenggaraan Pemerintahan Daerah dalam kerangka Negara Kesatuan Republik Indonesia. Sedangkan Pengawasan Penyelenggaraan Pemerintahan Daerah adalah usaha, tindakan, dan kegiatan yang ditujukan untuk menjamin penyelenggaraan Pemerintahan Daerah berjalan secara efisien dan efektif sesuai dengan ketentuan peraturan perundang-undangan.

Pasal 3 (1) Pembinaan Penyelenggaraan Pemerintahan Daerah: a. provinsi, dilaksanakan oleh: 1 . Menteri, untuk pembinaan umum; dan 2. menteri teknis/kepala lembaga pemerintah nonkementerian, untuk pembinaan teknis; b. kabupaten/kota, dilaksanakan oleh gubernur sebagai wakil Pemerintah Pusat untuk pembinaan umum dan teknis. (2) Pembinaan umum sebagaimana dimaksud pada ayat (1) huruf a angka 1 dan huruf b meliputi: a. pembagian urusan pemerintahan; b. kelembagaan daerah; c. kepegawaian pada Perangkat Daerah; d. keuangan daerah; e. pembangunan daerah; f. pelayanan publik di daerah; g. kerja sama daerah; h. kebijakan daerah; i. kepala daerah dan DPRD; dan j. bentuk pembinaan lain sesuai dengan ketentuan peraturan perundang-undangan.

Pasal 10 (1) Pengawasan Penyelenggaraan Pemerintahan Daerah: a. provinsi, dilaksanakan oleh: 1 . Menteri, untuk pengawasan umum; dan 2. menteri teknis/kepala lembaga pemerintah nonkementerian, untuk pengawasan teknis; b. kabupaten/kota, dilaksanakan oleh gubernur sebagai wakil Pemerintah Pusat untuk pengawasan umum dan teknis. (2) Pengawasan umum sebagaimana dimaksud pada ayat (1) huruf a angka 1 dan huruf b meliputi: a. pembagian urusan pemerintahan; b. kelembagaan daerah; c. kepegawaian pada Perangkat Daerah; d. keuangan daerah; e. pembangunan daerah; f. pelayanan publik di daerah; g. kerja sama daerah; h. kebijakan daerah; i. kepala daerah dan DPRD; dan j. bentuk pengawasan lain sesuai dengan ketentuan peraturan perundang-undangan. 
Presiden sebagai Kepala Pemerintahan memiliki tanggungjawab terhadap manajemen kepegawaian. Dalam menjalankan tugasnya tersebut, Presiden dibantu Komisi Kepegawaian. Adanya sistem karir dimanfaatkan untuk membina dan mengembangkan kemampuan Pegawai Negeri Sipil (PNS). Sehingga Pegawai Negeri Sipil dapat dinilai dari masa jabatan dan prestasi yang diraih untuk meningkatkan atau menaikan pangkat serta jabatannya. Namun sebelum proses tersebut, diklat sebelum jabatan atau diklat prajabatan harus dilalui terlebih dahulu bagi seorang Calon Pegawai Negeri Sipil sehingga nantinya pada saat menjadi Pegawai Negeri Sipil sudah dapat menguasai kemampuan umum dalam sebuah peraturan dan nantinya jika sudah menjadi PNS penuh diwajibkan untuk mengikuti pelatihan kembali yang bertujuan meningkatkan kemampuan kedalam jabatan agar dapat mengemban tugas-tugas pemerintahan, kenegaraan, dan pembangunan. Pangkat tertinggi untuk pejabat karier pada Pemerintah Provinsi adalah eselon I/b, sedangkan pengkat tertinggi untuk pejabat karier pada Pemerintah Kabupaten/Kota adalah eselon II/a.

\section{E. Quiz}

Provinsi Kalimantan Utara adalah salah satu Daerah Otonomi Baru (provinsi ke-34), yang disahkan dengan lahirnya Undang-Undang Nomor 20 Tahun 2012 tentang Pembentukan Provinsi Kalimantan Utara. Terdapat 1 kota dan 4 kabupaten yang tergabung kedalam Provinsi Kalimantan Utara. Terdapat beberapa alasan dibentuknya Provinsi Kalimantan Utara sebagai sebuah wilayah terpisah dari Provinsi Kalimantan Timur, yaitu ditinjau dari aspek geostrategis, geopolitik, potensi ekonomi, dan potensi kerjasama bilateral maupun regional.

Provinsi Kalimantan Utara yang terletak di belahan utara Pulau Kalimantan dan berbatasan langsung dengan Sabah-Malaysia, sangat 
berpotensi untuk menjaga kedaulatan dan martabat NKRI yang termanifestasikan dalam gerak dan tindak semua lapisan masyarakat di wilayah Kalimantan Utara terutama di daerah-daerah perbatasan dengan Malaysia. Namun kondisi ini juga menimbulkan berbagai macam tantangan karena sebagai Daerah Otonomi Baru, Kalimantan Utara masih harus terfokus pada aspek kelembagaan daerah. (Republika, 22 April 2013_Penulis : Ahmad Islamy Jamil)

Berdasarkan uraian diatas, jawablah beberapa pertanyaan berikut:

1) Apa yang melatar belakangi pembentukan Daerah Otonomi Baru Kalimantan Utara!

2) Bagaimana potensi tantangan yang dihadapi oleh Kalimantan Utara sebagai Daerah Otonomi Baru yang wilayahnya di ujung perbatasan!

3) Bagaimana penguatan kelembagaan yang perlu diperhatikan Kalimantan Utara sebagai Daerah Otonomi Baru!

\section{E. Simpulan}

Dalam menjalankan roda kepemerintahan daerah, dibutuhkan organisasi yang mengatur dan mengevaluasi setiap kebijakannya. Sehingga diharapakn tidak adanya ketimpang tindihan dalam menjalankan tugas-tugasnya. Organisasi-organisai tersebut akan dapat menjawab segala permasalahan yang berada di lingkungan pemerintah daerah yang kegiatan didalmnya bukan hanya persolan surat menyurat saja, melainkan adanya kegiatan mulai dari perencanaan kebijakan hingga pengawasan kebijakannya. Apalagi dengan adanya Undang-Undang Dasar 1945 yang menginstruksikan baik pemerintah provinsi, pemerintah kota ataupun pemerintah kabupaten dapat mengelola urusan urusan rumah tangganya sendiri. Disisi lain bentuk dari pemrintaha daerah di Indonesia terdiri Local Self Government dan Local State Government. Local Self Government sendiri dapat diartikan sebagai 
suatu kondisi yang dianggap bahwa pemerintah daerah lebih mampu mengetahui kebutuhannya dibandingkan dengan pemerintah pusat. Namun hal tersebut tetap tidak akan mamou menggeser posisi pemerintah pusat atau pemerintah negara sebagai sistem pemerintahan yang tertinggi dan utama. Sedangkan Local State Government adalah kondisi pemerintah daerah yang harus melaksanakan intruksi atau kebijakan dari pemerintah pusat yang telah diputuskan agar pemerintah daerah dapat menerapkan kebijakan tersebut.

\section{E. Daftar Pustaka}

Joeniarto. (1992). Perkembangan Pemerintahan Lokal . Jakarta : Bumi Aksara.

Mawhood, P. (1983). Local Government in The Third World. Chicester, UK: John Wisley and Sons.

Rosidin, U. (2010). Otonomi daerah dan desentralisasi. Bandung: Pustaka Setia.

Sujito, I. (1990). Hubungan Pemerintah Pusat dan Pemerintah Daerah. Jakarta: Rineka Cipta.

\section{BAB IV}

\section{Pembagian Kekuasaan ke Daerah}

\section{A. Deskripsi Singkat}

Undang-Undang Nomor 23 Tahun 2014 menjelaskan bahwa Pemerintah Daerah memiliki urusan pemerintahan konruen yang 
terbagi dalam a) Pemerintah Pusat, b) Pemerintah Provinsi, dan c) Pemerintah Daerah Kabupaten/Kota. Dalam urusan pemerintahan konruen terdapat urusan wajib pemerintah terkait dengan pelayanan dasar, non pelayanan dasar, pemerintahan pilihan, dan pemerintahan umum.

Desentralisasi melahirkan benih-benih otonomi yang membuka krankran kekuasaan, maka desentralisasi juga sering dianggap sebagai masalah. Jika dilihat dalam perjalanan otonomi yang sedang berjalan di Indonesia, maka kita tidak heran bahwa konflik-konflik baru muncul, seperti antara pemerintah pusat dengan pemerintan provinsi, pemerintah provinsi dengan Kabupetan dan seterusnya sampai kepada struktur yang paling kecil yang ada di wilayah tersebut.

Sebenarnya desentralisasi muncul sebagai gendre dan ikon yang sangat berkaitan dengan demokrasi, tata pengelolaan negara, hakhak masyarakat dalam bernegara, distribusi wewenang dan kekuasaan, serta tanggung jawab bersama antar negara.

Desentralisasi merupakan sebuah strategi bagaimana membuat demokrasi bekerja dalam sebuah negara. Jika dipahami sebagai pembuat kerangka bekerjanya demokrasi, maka distribusi kekuasaan baik dalam bidang politik, ekonomi dan lain sebagainya haruslah dijalankan secara demokrasi pula, dengan cara melibatkan secara keseluruhan aspek masyarakat sampai kepada tingkat yang paling rendah.

Pada Bab IV ini akan dijelaskan tentang pembagian kekuasaan ke daerah sebagai wujud dari pelaksanaan desentralisasi di Indonesia.

\section{B. Kompetensi Dasar}

Mahasisw mampu memahami dan mendeskripsikan pembagian kekuasaan ke daerah.

\section{Indikator}


1. Mahasiswa mampu mengetahui dan mengidentifikasi perlunya pembagian kekuasaan.

2. Mahasiswa mampu mengetahui dan mengidentifikasi cara pembagian kekuasaan.

3. Mahasiswa mampu mengetahui dan mengidentifikasi pembagian kekuasaan berdasarkan proses.

4. Mahasiswa mampu mengetahui dan mengidentifikasi pembagian kekuasaan berdasarkan pembagian fungsi.

5. Mahasiswa mempu mengetahui dan mengidentifikasi Hubungan Adp (Areal division of power) dengan Cdp (Capital division of power). 6. Mahasiswa mampu mengetahui dan mengidentifikasi hubungan pembagian kekuasaan pemerintah dengan non pemerintah.

\subsection{Perlunya Pembagian Kekuasaan}

Pembagian kekuasaan di Amerika Serikat telah berubah secara bertahap sejak Peranag Sipil sampai tahun 1933 dari eksklusif ke partisipasi berbagi. Pemerintah federal telah menentukan konstitusional yurisdiksi eksklusif yang dapat berdampak besar atas ketetapan yang dijalankan tersebut. Namun, disisi lain pada saat yang bersamaan, pemerintah pusat telah menyelenggarakan kekuasaan kepolisian federal di bawah klausa perdagangan sebagai penyempurnaan pada kewenangan kepolisian di negara bagian tersebut. Penggunaan kekuasaan yang dikenal dengan istilah 'grantsin-aid' telah diatur pembagian pada pemerintah negara bagian dan daerah dalam susunan fungsi atau urusan yang sangat luas. Pada faktanya, pembagian kekuasaan ini telah berjalan terlampau jauh. Hal tersebut dapat disimpulkan oleh beberapa akademisi sebagai aliran federalisme baru. Federalisme lama yang ada dalam konstitusi telah mengupayakan pemisahan antra fungsi secara eksklusif, sehingga terkesan masih bersifat kaku dan statis secara alamiah. Sedangkan pada federalisme baru telah bersifat dinamis, dimana 
suatu mekanisme dalam fungsi yang diserahkan kembali kepada beberapa jenjang pemerintahan baik secara eksklusif maupun berbagi bersama bergantung pada tuntutan periode/masa. Pada federalisme lama, sebagian telah terbentuk oleh persyaratan yang bertujuan dalam menghubungkan dan mempersatukan komunitas bebas sebelumnya. Profesor Macmahon menyatakan sebagai 'kemunculan federalisme', sementara Ylvisaker menyatakan sebagai 'federalisme sebagai alat dalam masa perkenalan'. Federalisme baru pada masanya telah matang dan beranggapan bahwa penyatuan yang berhasil bertujuan untuk mendirikan negara yang bahagia.

Pemahaman yang baik pada makna tujuan pembagian kekuasaan akan sangat membantu dalam memahami arti pentingnya pembagian kekuasaan. Pembagian kekuasaan pemerintahan yakni lembaga pemerintahan sebagai alat atau instrumen dalam mencapai nilai-nilai atau tujuan masyarakat. Dilain sisi, bentuk pembagian kekuasaan sebenarnya telah mencerminkan nilai yang dianut oleh masyarakat jangka waktu tertentu. Setiap jangka waktu yang berbeda, menunjukkan bahwa masyarakat memiliki kecenderungan nilai yang berbeda pula. Sehingga, yang selanjutnya akan mempengaruhi pilihan bentuk pembagian kekuasaan pemerintahan.

Negara demokrasi modern memiliki nilai-nilai dasar dan landasan dalammelakukan pembagian kekuasaan negara. Pada umumnya nilai-nilai dasar yang telah dianut oleh negara-negara modern yakni liberty (kebebasan), equality (persamaan), dan welfare (kesejahteraan). Kekuasaan pemerintah terbagi dengan tujuan untuk melindungi individu dan kelompok dari tindakan sewenang-wenang pemerintah dan kekuasaan politik ekonomi yang sangat besar untuk meningkatkan kebebasan. Perihal tersebut berdampak dengan adanya konstitusional yang bersifat mengendalikan kekuasaan. 
Dalam rangka meningkatkan persamaan, kekuasaaan pemerintahan dapat dibagi untuk memberikan kesempatan besar bagi partisipasi warga dalam kebijakan publik. Hal ini merupakan efek demokratis. Dalam rangka meningkatkan kesejahteraan, kekuasaan pemerintahan dapat terbagi untuk memberikan jaminan pada tindakan pemerintah agar efektif dan efisien dalam pemenuhan kebutuhan masyarakat. Dalam rangka mencapai tiga nilai tersebut melalui pembagian kekuasaan tersebut, tentu bukanlah hal yang mudah. Tentunya, jika semuanya harus dicapai sekaligus dalam tingkatan yang tinggi maka tidak satu pun nilai dapat dimaksimalkan. Dalam rangka mengoptimalkannya, suatu kombinasi tertentu menjadi tantangan besar tersendiri bagi negara demokrasi konstitusional. Berikut adalah tipologi pembagian kekuasaan.

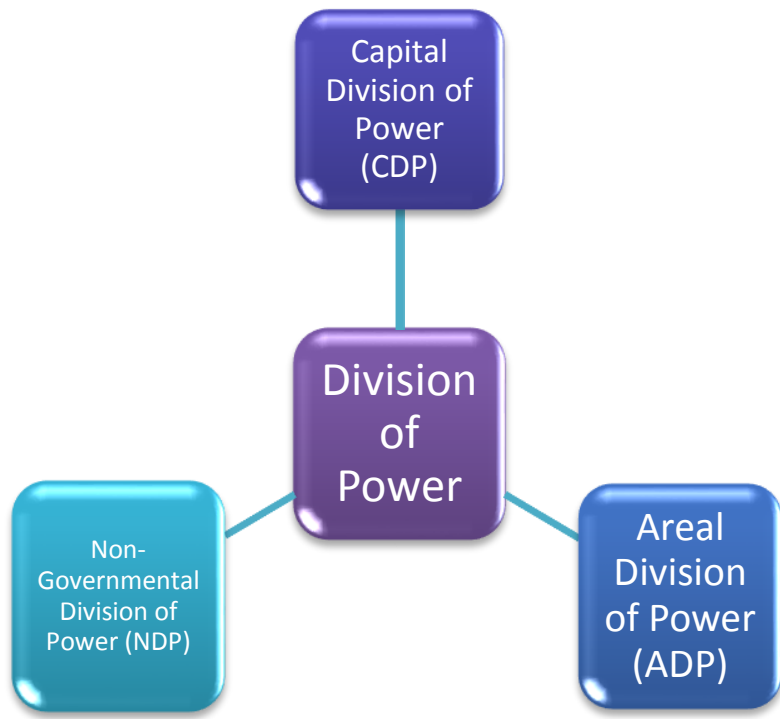

Gambar 4.1.

Tipologi Pembagian Kekuasaan 


\subsection{Cara Pembagian Kekuasaan}

Kekuasaan pemerintahan merupakan kemampuan dalam memerintah secara menyeluruh yang dijalankan oleh masyarakat politik tertentu. Kekuasaan masyarakat yang ada saat ini perlu diperhatikan. Artinya, harus ada keseimbangan pada kekuasaan dalam masyarakat dan berkaitan dengan metode pembagian kekuasaan, termasuk pembagian kekuasaan pemerintahan dengan non-pemerintahan. Kekuasaan pemerintahan dapat dibagi dalam berbagai cara.

Kemampuan untuk memerintah secara menyeluruh dibagi antara pejabat dan lembaga/institusi pemerintahan (seperti lembaga legislatif) di tingkat ibu kota. Metode ini dikenal dengan capital division of power ( $\mathrm{Cdp}$ ) atau horizontal division of power, yakni pembagian kekuasaan secara horizontal/sejajar. Metode tersebut merupakan adanya pembagian kekuasaan pada tataran/jenjang yang sama pada tingkat pusat. Pejabat atau lembaga/institusi yang terbentuk dari hasil pembagian kekuasaan yaitu sama-sama lembaga nasional yang mempunyai jenjang sederajat dengan jenis kekuasaan yang sama atau berbeda. Pejabat atau lembaga/intitusi pemerintahan yang dihasilkan melalui metode ini misalnya Presiden dengan Dewan Perwakilan Rakyat dan Mahkamah Agung.

Selain itu, kewenangan juga dapat terbagi antara Negara dengan wilayah yang ada atau yang dibentuk di Negara tersebut. Metode ini disebut sebagai areal division of powers (Adp) atau vertical division of power, yakni pembagian kekuasaan secara vertikal/berjenjang. Metode ini ialah pembagian kekuasaan yang berlangsung antara tingkatan pemerintahan yang berbeda. Pembagian kekuasaan yang dilakukan antara di tingkat pusat dan tingkat daerah. Pemerintahan yang memiliki jenjang lebih tinggi yaitu pusat atau nasional, 
sedangkan pemerintahan daerah memiliki kedudukan yang lebih rendah. Selanjutnya, pembagian kekuasaan ini dapat dilakukan diantara lembaga negara di ibu kota dan diantara jenjang/level pemerintahan melalui berbagai metode yang berbeda berdasarkan proses, fungsi, dan konstituensi.

\subsection{Pembagian Kekuasaan Berdasarkan Proses}

Pasal 18 ayat (1) UUD Negara Republik Indonesia Tahun 1945 menyatakan bahwa Negara Kesatuan Republik Indonesia dibagi atas daerah-daerah provinsi dan daerah provinsi itu dibagi atas kabupaten dan kota, yang tiap-tiap provinsi, kabupaten, dan kota itu mempunyai pemerintahan daerah, yang diatur dengan undang-undang. Berdasarkan ketentuan tersebut, pembagian kekuasaan secara vertikal di negara Indonesia berlangsung antara pemerintahan pusat dan pemerintahan daerah (pemerintahan provinsi dan pemerintahan kabupaten/kota). Pada pemerintahan daerah berlangsung pula pembagian kekuasaan secara vertikal yang ditentukan oleh pemerintahan pusat. Hubungan antara pemerintahan provinsi dan pemerintahan kabupaten/kota terjalin dengan koordinasi, pembinaan dan pengawasan oleh Pemerintahan Pusat dalam bidang administrasi dan kewilayahan. Pembagian kekuasaan secara vertikal muncul sebagai konsekuensi dari diterapkannya asas desentralisasi di Negara Kesatuan Republik Indonesia. Dengan asas tersebut, Pemerintah Pusat menyerahkan wewenang pemerintahan kepada pemerintah daerah otonom (provinsi dan kabupaten/kota) untuk mengurus dan mengatur sendiri urusan pemerintahan di daerahnya, kecuali urusan pemerintahan yang menjadi kewenangan Pemerintah Pusat, yaitu kewenangan yang berkaitan dengan politik luar negeri, pertahanan, keamanan, yustisi, agama, moneter dan fiskal. Hal tersebut ditegaskan dalam Pasal 18 ayat (5) UUD Negara Republik Indonesia Tahun 1945 yang menyatakan Pemerintah daerah 
menjalankan otonomi seluas-luasnya, kecuali urusan pemerintahan yang oleh undang-undang ditentukan sebagai urusan Pemerintah Pusat. Pemberian otonomi kepada daerah bertujuan meningkatkan daya guna dan hasil guna penyelenggaraan pemerintahan di daerah, terutama dalam pelaksanaan kepada masyarakat maupun meningkatkan kestabilan politik dan kesatuan bangsa.

\subsection{Pembagian Kekuasaan Berdasarkan Pembagian Fungsi}

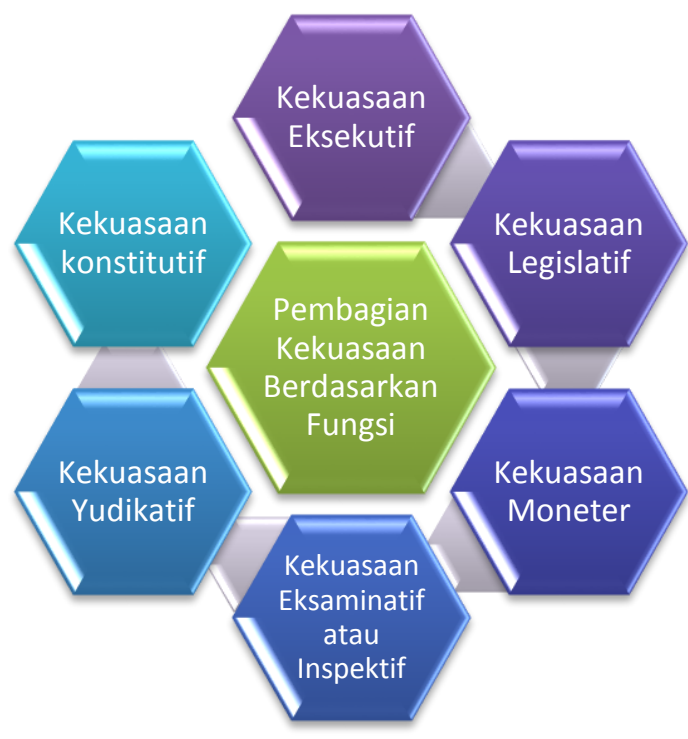

Gambar 4.2.

\section{Pembagian Kekuasaan Berdasarkan Fungsi}

Pembagian kekuasaan menurut fungsi lembaga-lembaga terdiri dari tiga jenis yaitu legislatif, eksekutif dan yudikatif. Pembagian kekuasaan negara secara horizontal dilakukan pada tingkat pemerintahan pusat dan pemerintahan daerah berdasarkan UUD Negara Republik Indonesia Tahun 1945. Pembagian kekuasaan pada tingkat pemerintahan pusat berlangsung antara lembaga-lembaga negara yang sederajat. Pembagian kekuasaan pada tingkat 
pemerintahan pusat mengalami perubahan setelah adanya amandemen UUD Negara Republik Indonesia Tahun 1945. Pergeseran tersebut adalah pergeseran klasifikasi kekuasaan negara yang umumnya terdiri atas tiga jenis kekuasaan (legislatif, eksekutif dan yudikatif) menjadi enam kekuasaan negara, yaitu:

a. Kekuasaan konstitutif, yaitu kekuasaan untuk mengubah dan menetapkan Undang-Undang Dasar. Pasal 3 ayat (1) UUD 1945 menjelaskan bahwa kekuasaan konstitutif dijalankan oleh Majelis Permusyawaratan Rakyat yang berwenang mengubah dan menetapkan Undang-Undang Dasar.

b. Kekuasaan eksekutif, yaitu kekuasaan untuk menjalankan undang-undang dan penyelenggaraan pemerintahan Negara. Hal tersebut juga dapat dijelaskan dalam Pasal 4 ayat (1) Undang-Undang Dasar 1945 yang menjelaskan mengenai kewenangan eksekutif dipegang oleh Presiden menurut Undang-Undang Dasar.

c. Kekuasaan legislatif, yaitu kekuasaan untuk membentuk undang-undang. Pasal 20 ayat (1) UUD 1945 menjelaskan bahwa kekuasaan legislatif dipegang oleh Dewan Perwakilan Rakyat yang berwenang membentuk undang-undang.

d. Kekuasaan yudikatif atau disebut kekuasaan kehakiman, yaitu kekuasaan untuk menyelenggarakan peradilan guna menegakkan hukum dan keadilan. Pasal 24 ayat (2) UUD 1945 menjelaskan bahwa kekuasaan yudikatif dipegang oleh Mahkamah Agung dan badan peradilan yang berada di bawahnya dalam lingkungan peradilan umum, lingkungan peradilan agama, lingkungan peradilan militer, lingkungan peradilan tata usaha negara, dan oleh sebuah Mahkamah Konstitusi. 
e. Kekuasaan eksaminatif/inspektif, yaitu kekuasaan yang berhubungan dengan penyelenggaraan pemeriksaan atas pengelolaan dan tanggung jawab tentang keuangan negara. Pasal 23 E ayat (1) UUD 1945 Negara Republik Indonesia menjelaskan bahwa kekuasaan eksaminatif/inspektif dijalankan oleh Badan Pemeriksa Keuangan (BPK) yang bebas dan mandiri untuk memeriksa pengelolaan dan tanggung jawab tentang keuangan negara yang bebas dan mandiri.

f. Kekuasaan moneter, yaitu kekuasaan untuk menetapkan dan melaksanakan kebijakan moneter, mengatur dan menjaga kelancaran sistem pembayaran, serta memelihara kestabilan nilai rupiah. Pasal 23 D UUD 1945 menjelaskan bahwa kekuasaan moneter dijalankan oleh Bank Indonesia selaku bank sentral di Indonesia yang susunan, kedudukan, kewenangan, tanggung jawab, dan indepedensinya diatur dalam undang-undang.

Pembagian kekuasaan secara horizontal pada tingkatan pemerintahan daerah berlangsung antara lembaga-lembaga daerah yang sederajat, yaitu antara Pemerintah Daerah (Kepala Daerah/Wakil Kepala Daerah) dan Dewan Perwakilan Rakyat Daerah (DPRD). Pada tingkat provinsi, pembagian kekuasaan berlangsung antara Pemerintah provinsi (Gubernur/wakil Gubernur) dan DPRD provinsi. Sedangkan pada tingkat kabupaten/kota, pembagian kekuasaan berlangsung antara Pemerintah Kabupaten/Kota (Bupati/wakil Bupati atau Walikota/wakil Walikota) dan DPRD kabupaten/kota.

\subsection{Hubungan Adp (Areal division of power) dengan Cdp (Capital division of power)}

Hubungan antara Adp dengan susunan kekuasaan di tingkat pusat harus diwaspadai sebagai akibat adanya fokus perhatian pada 
pembagian kekuasaan berdasarkan wilayah (Adp). Hubungan kekuasaan Adp dan Cdp saling mempengaruhi satu dengan yang lainnya. Adp terbagi dalam kekuasaan berdasarkan wilayah dan Cdp sebagai penentu dalam pembagian kekuasaan di pusat. Berdasarkan hal tersebut, maka terdapat satu atau lebih pasangan nilai Adp dan Cdp yang akan menghasilkan kesatuan kebebasan, kesamaan, dan kesejahteraan yang optimum/maksimal dalam kondisi dan faktor lain bersifat konstan.

Cdp yang mempunyai orinetasi pada sentralisasi berkaitan erat dengan Adp yang berorientasi pada desentralisasi. Hubungan kedua kekuasaan diatas bersifat kontinum. Desentralisasi bukan berarti dimaknai dalam melepaskan sentralisasi, karena sesungguhny kedua orinetasi berada pada jalur atau garis yang berkelanjutan. Desentralisasi serta sentralisasi tidak untuk saling meniadakan, melainkan untuk saling melengkapi satu dengan yang lainnya sebagai suatu tatanan yang memberikan kemanfaatan dalam mencapai tuiuan-tujuan pemerintahan. Oleh sebab itu, penerapan/pelaksanaan dari desentralisasi secara tepat dalam pengertian yang luas mampu memenuhi tujuan pemerintahan. Pada titik ekstrim sentralisasi absolut mengindikasikan bahwa tidak terdapatnya pembagian kekuasaan pada daerah dikarenakan hal tersebut mutlak menjadi kewenangan pemerintah pusat. Sehingga jika diterpakan pada kondisi negara yang mempunyai jumlah penduduk yang banyak, maka dibutuhkan kolaborasi yang epik diantara konsep sentralisasi dan desentralisasi agar dapat berjalan seimbang demi tujuan bersama yang lebih kuat. 


\subsection{Hubungan Pembagian Kekuasaan Pemerintah dengan Non Pemerintah}

Hingga detik ini, adanya anggapan bahwa pengelolaan kekuasaan non pemerintah dalam masyarakat mendapatkan perhatian yang kurang sehingga pembagian kekuasaan lebih dititikberatkan pada kekuasaan pemerintahan dan masyarakat politik. Kekuasaan non pemerintah sesungguhnya telah memiliki peranan yang strategis dalam mencapai tujuan pemerintahan yang optimal sehingga dalam konsep Governance pada kekuasaan non pemerintah diberi bagian perhatian yang sama kuatnya. Perhatian terhadap sektor non pemerintah melingkupi pembagian kekuasaan pemerintah dengan kekuasaan non pemerintah, mutu relatif yang dikaitkan dengan Adp dan Cdp dalam setiap pembagian, dan metode pembagiannya. Hal ini menjadi fungsi dari organisasi masyarakat dan struktur kekuasaan dari masyarakat.

Dengan demikian hubungan yang erat ini, menjadi sebuah tujuan bagi para peneliti yang tertarik dengan wewenang non pemrintah serta yang ingin mempelajari ADP juga. Sehingga Ylvisaker melakukan analisis secara eksplisit dan berasumsi bahwa terdapat keseimbangan kekuatan dalam masyarakat. Keadaan konsep NDP yang mudah dipahami menjadikan konsep tersebut dapat diterapkan dimana saja diakrenakan konsep ini mempunyai keseimbangan wewenang dalam tatanan sistem kepemerintahan. Sehingga, dampaknya yakni terdapat perubahan-perubahan dalam struktur kekuasaan masyarakat secara signifikan, misalkan peningkatn pertumbuhan wilyah kota, yang mempunyai konsekuensi penting bagi pembagian kekuasan pemerintahan. 


\section{Quiz}

Sumber daya alam adalah kekayaan daerah yang dapat dimanfaatkan untuk menggali sumber-sumber pendapatan. Otonomi daerah telah memberikan hak kepada Pemerintah Daerah untuk mengelola dan mengembangkan potensi sumber daya alam, namun harus tetap berpedoman pada Undang-Undang yang berlaku.

Pada pelaksanaannya, pengelolaan sumber daya alam di era otonomi banyak menimbulkan dampak negatif. Perambahan hutan mangrove di Kota Kendari semakin parah, bahkan tanpa adanya upaya penindakan dari Pemerintah Kota Kendari dan aparat penegak hukum. Bank Swasta Artha Graha mengklaim memiliki tanah di kawasan mangrove Teluk Kendari. Salah satu anggota DPRD Sulawesi Tenggara (Salam) mempertanyakan darimana asal kepemilikan Artha Graha terhadap lahan mangrove tersebut. Pihaknya menduga bahwa ada kongkalikong antara Artha Graha dengan Pemerintah Kota Kendari. Apabila lahan mangrove tersebut beralih fungsi, maka akan merugikan lingkungan. Hal itu tentu akan melanggar Undang-Undang karena setiap orang atau lembaga dilarang untuk melakukan konservasi yang tidak memperhatikan keberlanjutan fungsi ekosistem. (Telisik Indonesia, 13 Mei 2020_Penulis : Siswanto Azis) 


\section{DPRD Sultra Pertanyakan Asal Kepemilikan Lahan Arta Graha di Teluk Kendari}

(B) Siswanto Azis, telisik indonesia || Rabu, 13 Mei 2020 || 1086 dillihat

\section{$\oplus>0$}

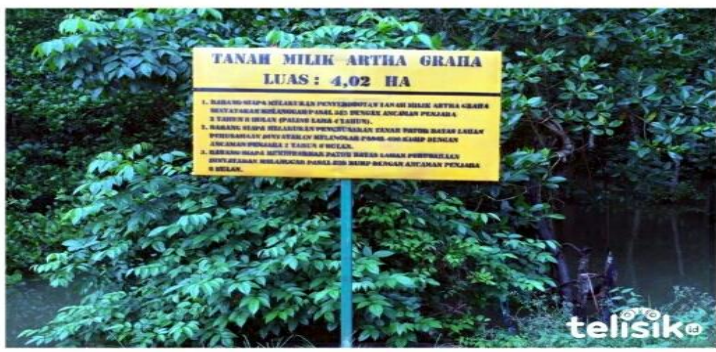

Plank Arta Graha di hutan mangrove Teluk Kendari. Foto: Dul/Telisik

Berdasarkan uraian diatas, jawablah beberapa pertanyaan berikut:

1) Menurut pendapat anda, apakah kepemilikan lahan mangrove oleh Bank Artha Graha termasuk pembagian kekuasaan pemerintah dengan non pemerintah, jelaskan beserta alasannya?

2) Bagaimana kewenangan pemerintah kabupaten/kota dalam mengelola hutan mangrove menurut Undang-Undang!

3) Deskripsikan saran dan masukan Saudara, solusi dalam mengatasi permasalahan diatas!

\section{E. Simpulan}

Di indonesia terdapat tiga urusan kepemerintahan yaitu pemerintah pusat, pemerintah provinsi dan pemerintah daerah/ kabupaten. Oleh karena itu agar kepemerintahan dapat berjalan optimal dan efektif, tugas kepemerintahn tersebut dapat dibagi kekuasaanya di daerah. Pembagian kekuasaan menjadi titik kejelasan mengenai perbedaan kekuasaan pemerintah pusat, provinsi ataupun daerah. Keadaan tersebutlah menjadi peran penting dari adanya 
pembagian kekuasaan. Indonesia adalah negara yang demokrasi, dimana dalam menjalankan pembagian kekuasaan daerahnya masih terdapat tipologi dalam penerapannya yaitu Capital Division Of Power (CDP), Areal Division Of Power (ADP) dan Non Government Division Of Power (NDP). Meskipun ketiga kekuasaan tersebut dikenal sebagi tipologi namun tipologi tersebut berperan penting bagi pembagian kekuasaan dalam pembangunan baik pembangunan nasional, provinsi ataupun daerah, seperti halnya keterkaitan hubungan diantara ADP dan CDP. Secara sederhananya untuk memahabi hubungan tersebut CDP adalah kekuasaan pemerintah pusat dan ADP adalah kekuasaan pemerintah daerah. Dalam mencapai tujuannya, ADP menggunakan asas desentralistik yaitu asas yang dapat mengatur urusan rumah tangganya sendiri yaitu membuat kebijakans esuai dengan kebutuhannya daerah itu sendiri, namun ADP tidak dapat menjalankan kebijakan tersebut tanpa mengikuti aturan dari CDP. Hal tersebut dikarenakan semua kebijakan pemerintah daerah harus bersinergi dengan cita-cita pembangunan pemerintah pusat agar dapat mencapai tujuan yang lebih besar. Berbeda halnya denagn NDP, NDp dapat dipahami sebagai pembangunan daerah tidak dapat berhasil jika organisasiorganisai yang terdapat di daerah tidak menyetujui pembangunan atau kebijakan tersebut untuk direalisasikan dan akan terjadi demonstrasi di daerah-daerah.

\section{F. Daftar Pustaka}


Ichsan, Supriyono, \& Muluk. (2006). Variasi Cakupan dan Peran Pelayanan Publik Pemerintah Derah. Malang: Kerjasama LPM Unibraw dan Bappenas.

Kaputra, I., dkk. (2013). Dampak otonomi daerah di Indonesia: Merangkai sejarah poitik dan pemerintahan Indonesia. Jakarta: Yayasan Pustaka Obor Indonesia.

Nasution, A. B. (2000). Federalisme Untuk Indonesia. Jakarta: Kompas.

Riwu, J. (2008). Prospek Otonomi Daerah di Negara Republik Indonesia . Jakarta: PT. Raja Grafindo Perkasa. 


\section{A. Deskripsi Singkat}

Keuangan daerah adalah semua hak dan kewajiban daerah yang dapat dinilai dengan uang dan segala sesuatu berupa uang dan barang yang dapat dijadikan milik daerah yang berhubungan dengan pelaksanaan hak dan kewajiban tersebut. Tidak dipungkiri bahwa support system yang paling mempengaruhi adalah faktor keuangan. Faktor keuangan dapat mengukur sejauh mana kemampuan pemerintah daerah dalam mengurus dan mengatur urusan rumah tangganya serta melaksanakan otonomi pada daerahnya. Selain itu mengatur dalam hal keuangan dapat pula menjadi pedoman bagi masyarakat untuk menilai kinerja para aparat dalam mengelola keuangan di daerahnya. Oleh karena itu, suatu hal yang paling disoroti dalam roda kepemimpinan adalah kemampuan pengelolaan akan faktor keuangan.

Kemampuan Pemerintah wilayah atau Daerah dalam mengelola keuangannya dituangkan dalam Anggaran Pendapatan dan Belanja Daerah (APBD) yang langsung maupun tidak langsung. Kemampuan pemda dalam mengelola keuangan daerah dituangkan dalam Anggaran Pendapatan dan Belanja Daerah (APBD) yang langsung maupun tidak langsung mencerminkan kemampuan pemda dalam membiayai pelaksanaan tugas-tugas pemerintahan, pembangunan dan pelayanan sosial masyarakat.

\section{B. Kompetensi Dasar}

Mahasiswa mampu memahami dan mengidentifikasi keuangan daerah.

\section{Indikator}

1. Mahasiswa mampu mengetahui dan mengidentifikasi sumber pendapatan daerah.

2. Mahasiswa mampu mengetahui dan mengidentifikasi sumber pengeluaran daerah. 
3. Mahasiswa mampu mengetahui dan mengidentifikasi pengelolaan keuangan daerah.

4. Mahasiswa mampu mengetahui dan mengidentifikasi pemegang kekuasaan pengelolaan keuangan daerah.

5. Mahasiswa mampu mengetahui dan mengidentifikasi pejabat pengelolaan keuangan daerah.

\subsection{Sumber Pendapatan Daerah}

Pendapatan Daerah bersumber Pendapatan Asli Daerah (PAD), Dana Perimbangan, dan Lain-lain Pendapatan Daerah yang sah.

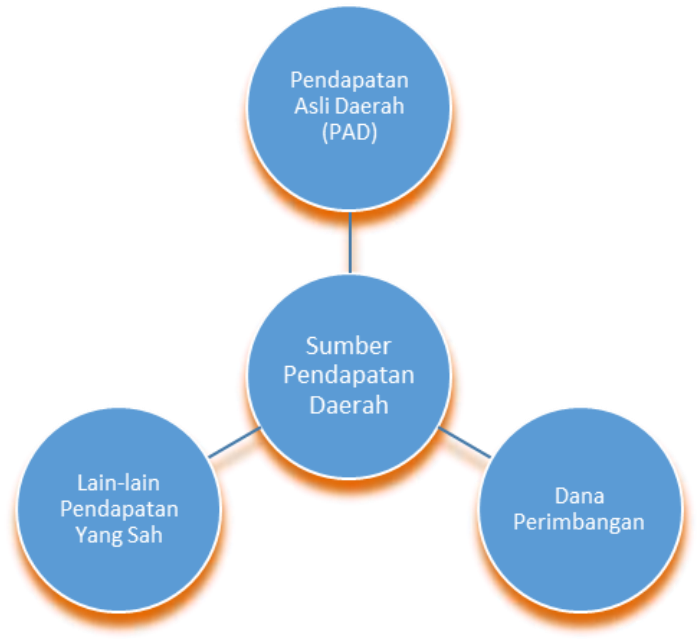

Gambar 5.1.

\section{Sumber Pendapatan Daerah}

1. Pendapatan Asli Daerah (PAD)

Pendapatan Asli Daerah (PAD) merupakan penerimaan yang diperoleh daerah dari sumber-sumber dalam wilayahnya sendiri yang dipungut berdasarkan peraturan daerah sesuai dengan peraturan perundang-undangan yang berlaku (Abdul Hakim, 2004:94). Selain itu Kementerian keuangan menjelasakan di laman websitenya bahwa PAD adalah pemasukkan yang didapatkan oleh pemerinatah daerah 
dari hasil pungutan yang berpedoman pada peraturan daerah sesuai dengan peraturan perundang-undangan. PAD berasal dari hasil pajak daerah, retribusi daerah, pengelolaan kekayaan daerah yang dipisahkan, dan lain-lain pendapatan asli daerah yang sah. PAD bertujuan agar daerah dapat leluasa untuk menggali pendanaan dalam pelaksanaan otonomi daerah sebagai perwujudan asas desentralisasi. Peningkatan kemandirian daerah sangat erat kaitannya dengan kemampuan daerah dalam mengelola Pendapatan Asli Daerah, semakin tinggi kemampuan daerah untuk menghasilkan Pendapatan Asli Daerah maka semakin besar pula kemampuan daerah untuk menggunakan Pendapatan Asli Daerah tersebut sesuai dengan kebutuhan dan prioritas pembangunan daerah. Hal tersebut mebjadi keterkaitan hubungan Pendapatan Asli Daerah dengan belanja modal.

Mardiasmo didalam bukunya pada tahun (2004) menjelaskan bahwa selama ini PAD memiliki peran untuk membiayai pelaksanaan otonomu daerah guna mencapai tujuannya yang utama yaitu penyelenggaraan otonomi daerah yang ingin meningkatkan pelayanan publik dan memajukan perekonomian pada daerahnya. Bermula dari harapan tersebut, Pemerintah Daerah melakukan segala cara salah satunya adalah pemerintah daerah dapat meningkatkan pelayanan publik dan kesejahteraan masyarakat dengan meningkatkan belanja modal.

\section{Dana Perimbangan}

Dana perimbangan adalah Adalah dana yang bersumber dari pendapatan APBN yang dialokasikan kepada Daerah untuk mendanai kebutuhan daerah dalam rangka pelaksanaan desentralisasi (Departemen Keuangan, 2004). Pendapatan yang termasuk ke dalam dana perimbangan terdapat dalam Undang-undang Nomor 33 Tahun 2004 Tentang Perimbangan Antar Keungan Pemerintah Pusat dan Daerah yaitu: 


\section{Bagi Hasil Pajak}

Sumber dana bagi hasil pajak didapatkan dari Pajak Bumi dan Bangunan (PBB), pajak perolehan hak atas tanah dan bangunan (PPHTB) serta Pajak penghasilan (PPH).

2. Bagi Hasil Non Pajak

Dana bagi hasil non pajak didapatkan melalui beberapa sumber diantaranya Iuran Hak Pengusahaan Hutan (IHPH), Provisi Sumber Daya Hutan (PSDH), Dana Reboisasi Iuran Tetap/Landrent, Iuran Eksplorasi dan luran Eksploitasi (Royalti), Pendapatan Pungutan Pengusahaan Perikanan, Pendapatan Pungutan Hasil Perikanan, Pertambangan Minyak Bumi, Pertambangan Gas Alam serta Pertambangan Panas Bumi.

\section{Dana Alokasi Umum}

Dana Alokasi Umum (DAU) menurut (Bratakusumah, 2004:183) dana yang bersumber dari pemerintah pusat ke pemerintah daerah yang dimaksudkan untuk menutup kesenjangan fiskal (fiscal gap) dan pemerataan kemampuan fiskal antar daerah dalam rangka membantu kemandirian pemerintah daerah menjalankan fungsi dan tugasnya melayani masyarakat. Besaran DAU ditetapkan sekurangkurangnya 26\% dari Pendapatan Dalam Negeri (PDN) Netto yang ditetapkan dalam APBN. Contohnya biaya untuk peningkatan infrastruktur transportasi untuk mengurangi efek overload di ruasruas jalan Kabupaten.

\section{Dana Alokasi Khusus}

Menurut Yani (2009:165) Dana yang bersumber dari pendapatan pemerintah pusat yakni melalui APBN yang dialokasikan kepada daerah tertentu untuk dengan tujuan untuk membantu mendanai kebutuhan khusus yang merupakan urusan daerah dan sesuai dengan prioritas nasional. Ada tiga kriteria yaitu Kebutuhan tidak dapat diperhitungkan dengan menggunakan rumus dana alokasi 
umum, Kebutuhan merupakan komitmen atau prioritas nasional serta Kebutuhan untuk membiayai kegiatan reboisasi dan penghijauan oleh daerah penghasil. Dengan demikian DAK pada dasarnya merupakan transfer yang bersifat spesifik untuk tujuantujuan yang sudah digariskan.

3. Lain-Lain Pendapatan Yang Sah

Menurut Halim (2007) lain-lain pendapatan yang sah merupakan pendapatan yang penerimaannya berasal dari lain-lain milik pemerintah daerah. Berdasarkan Undang-Undang Nomor 33 tahun 2004 lain-lain pendapatan asli daerah yang sah meliputi:

1. Hasil penjualan kekayaan daerah yang tidak dipisahkan

2. Jasa giro

3. Pendapatan bunga

4. Keuntungan selisih nilai rupiah terhadap uang asing

5. Komisi, potongan ataupun bentuk lain sebagai akibat dari bentuk penjualan dan atau pengadaan barang dan atau jasa oleh daerah.

\subsection{Sumber Pengeluaran Daerah}


Belanja

Langsung

\section{Sumber \\ Pengeluaran \\ Daerah}

Belanja

Tidak

Langsung

\section{Gambar 5.2. \\ Sumber Pengeluaran Daerah}

Pengeluaran Daerah menurut Peraturan Pemerintah Nomor 24 Tahun 2015 tentang Standar Akuntansi Pemerintahan Pernyataan Nomor 2 adalah Semua pengeluaran dari Rekening kas umum negara/daerah yang mengurangi ekuitas dana lancar dalam

periode tahun anggaran bersangkutan yang tidak akan diperoleh pembayarannya kembali oleh pemerintah. Sumber Pengeluaran Daerah dibagi menjadi dua yaitu:

1. Belanja Langsung

Menurut permendagri Nomor 13 tahun 2006 belanja langsung adalah belanja yang dianggarkan terkait secara langsung dengan pelaksanaan program-program merupakan penjabaran kebijakan SKPD dalam bentuk upaya yang berisi satu atau lebih kegiatan dengan mengunakan sumber daya yang disediakan untuk mencapai 
hasil yang terukur sesuai dengan misi SKPD. Belanja langsung terdiri dari belanja pegawai, belanja barang dan jasa serta belanja modal.

2. Belanja Tidak Langsung

Menurut permendagri No 13 Tahun 2006 belanja tidak langsung merupakan belanja yang dianggarkan tidak terkait secara langsung dengan pelaksanaan program dan kegitan. Kelompok belanja tidak langsung dibagi menurut jenis belanja yang tediri dari : Belanja pegawai; Bunga; Subsidi; Hibah; Bantuan Sosial; Belanja bagi Hasil; Bantuan Keuangan; dan Belanja Tidak Terduga

\subsection{Pengelolaan Keuangan Daerah}

Pengelolaan keuangan daerah dilaksanakan oleh pemegang kekuasaan pengelola keuangan daerah. Kepala daerah selaku kepala pemerintah daerah adalah pemegang kekuasaan pengelolaan keuangan daerah dan mewakili pemerintah daerah dalam kepemilikan kekayaan daerah yang dipisahkan. Kepala daerah perlu menetapkan pejabat-pejabat tertentu dan para bendahara untuk melaksanakan pengelolaan keuangan daerah. Para pengelola keuangan daerah tersebut adalah:

a. Koordinator Pengelolaan Keuangan Daerah (Koordinator PKD). Koordinator PKD mempunayi tugas untuk mengkoordinasikan di bidang penyusunan dan pelaksanaan kebijakan pengelolaan APBD; penyusunan dan pelaksanaan kebijakan pengelolaan barang daerah; penyusunan rancangan APBD dan rancangan perubahan APBD; penyusunan Raperda APBD; mamantau tugas-tugas pejabat perencanan daerah; PPKD dan pejabat pengawas keuangan daerah;memimpin tim anggaran pemerintah daerah; serta penyusunan laporan keuangan daerah dalam rangka pertanggungjawaban pelaksanaan APBD

b. Pejabat Pengelola Keuangan Daerah (PPKD). PPKD mempunyai tugas menyusun dan melaksnakan kebijakan 
pengelolaan keuangan daerah; menyusun rancangan APBD dan rancangan perubahan APBD; Melaksanakan pemungutan pendapatan daerah yang telah ditetapkan dengan Peraturan daerah; melaksanakan fungsi Bendahara Umum Daerah (BUD); menyusun laporan keuangan daerah dalam rangka pertanggungjawaban pelaksanaan APBD serta melaksanakan tugas lainnya berdasarkan kuasa yang diberikan oleh Kepala Daerah.

c. Pejabat Pengguna Anggaran/Pengguna Barang (PPA/PB). PPA/PB mempunyai tugas dan wewenang dalam hal menyusun RKASKPD; menyusun DPA-SKPD; melaksanakan kegiatan yang mengakibatkan pengeluaran atas beban anggaran belanja; melaksanakan anggran SKPD yang dipimpinnya; melaksanakan pemungutan penerimaan yang bukan hasil dari pajak; mengadakan perjanjian kerjasama dengan pihak lain dalam batas anggaran yang telah ditetapkan; mengelola utang dan piutang yang menjadi tanggung jawab SKPD yang dipimpinnya; mengelola barang milik daerah atau kekayaan daerah yang menjadi tanggung jawab SKPD yang dipimpinnya; mengawasi pelaksanaan anggaran SKPD yang dipimpinnya; melaksanakan tugas-tugas penggunan anggran atau pengguna barang lainnya berdasarkan kuasa yang dilampahkan oleh Kepala Daerah. Pejabat Pengguna Anggaran dapat melimpahkan sebagian kewenangannya kepada kepala unit kerja pada SKPD selaku kuasa pengguna anggaran atau pengguna barang.

d. Pejabat Pelaksana Teknis Kegiatan (PPTK). PPTK mempunyai tugas dan fungsi dalam mengendalikan pelaksanaan kegiatan; melaporkan perkembangan pelaksanaan kegiatan; serta menyiapkan dokumen anggaran atas beban pengeluaran pelaksanaan kegiatan.

e. Pejabat Penatausahaan Keuangan Satuan Kerja Perangkat Daerah (SKPD). Pejabat Penatausahaan Keuangan SKPD memiliki tugas dan fungsi dalam mengelola keuangan daerah dalam hal meneliti kelengkapan SPP-LS yang diajukan oleh PPTK; meneliti 
kelengkapan SPP-UP, SPP-GU dan SPP-TU yang diajukan oleh bendahara pengeluaran; menyiapkan SPM; serta menyiapkan laporan keungan SKPD.

f. Bendahara Penerimaan dan Bendahara Pengeluaran. Pada bagian ini Bendahara Penerimaan dan Bendahara Pengeluaran mempunyai tugas dan fungsi melaksanakan tugas kebendaharaan dalam rangka pelaksanaan anggaran pendapatan pada SKPD; melaksanakan kebendaharaan dalam rangka pelaksnaan anggarn belanja pada SKPD; bertanggung jawab atas pelaksanaan tugasnya kepada PPKD selaku BUD.

Peraturan Pemerintah menjelaskan dalam pasalnya bahwa dalam mengelola keuangan daerah, pemerintah daerah harus berlandaskan asas umum pengelolaan keuangan daerah yang dijealsakan sebagai berikut:

1. Bahwa keuangan daerah harus dikelola secara tertib, taat pada regulasi yang berlaku, dimanfaatkan dengan sebaik-baiknya (efektif), terbuka (transparan) dan dapat dipertanggung jawabkan dengan memperhatikan rasa keadilan, kepatutan dan kebermanfaatan bagi masyarakat daerah.

2. dalam mengelola keuangan daerah harus dilaksanan dalam suatu sistem yang terintegrasi yang dapat diwujudkan bentuknya dalam APBD yang setiap tahunnya dengan peraturan Daerah. Menambhakan hal tersebut Kementerian Dalam Negeri mengeluarkan Peraturan Dalam Negeri Nomor 13 Tahun 2006 bahwa yang dimaksud dengan taat pada perundang-undangan adalah mengenai pengelolaannya, pemerintah daerah tidak boleh lepas kontrol dari peraturan yang lainnya. Sehingga Pemerintah daerah harus berpedoman pada peraturan perundang-undangan. Sedangkan yang dimaksud dengan efektif dan efisien adalah bagaimana cara pemerintah daerah agar dapat mengelola keuangan daerahnya untuk mencapai tujuannya. Dengan kata lain kemampuan 
pemerintah daerah mencapai output yang maksimal dengan menggunakan keuangan daerah yang minimal. Sedangkan yang dimaksud ekonomis merupakan pemerolehan masukan dengan kualitas dan kuantitas tertentu pada tingkat harga yang terendah. Sedangkan transparan merupakan pemberian akses secara terbuka kepada masyarakat untuk memperoleh informasi mengenai keuangan daerah. Asas umum lainnya adalah bertanggung jawab. Bertanggung jawab dapat diartikan sebagai perwujudan kewajiban pemerintah daerah untuk mempertanggungjawabkan pengelolaan dan pengendalian sumber daya dan pelaksanaan kebijakan yang dipercayaakan kepadanya dalam rangka pencapaian tujuan yang telah ditetapkan. Sedangkan Keadilan adalah berimbangnya distribusi kewenangan dan pendanaannya dan atau berimbangnya distribusi hak dan kewajiban berdasarkan pertimbangan yang obyektif. Kepatutan adalah suatu tindakan atau sikap yang dilakukan dengan wajar dan proporsional. Sedangkan asas umum yang terakhir adalah asas manfaat untuk masyarakat. Asas manfaat untuk masyarakat adalah dam mengelola keuangan daerah, pemerintah daerah harus mengutamakan kebutuhan masyarakat. Jadi ada sembilan asas umum dalam mengelola keuangan daerah bersarkan Kementerian Dalam negeri yaitu asas taat pada peraturan perundang-undangan, asas efketif, asas efisien, asas ekonomis, asas transparan, asas bertanggung jawab, asas keadilan, asas kepatutan, dan asas manfaat untuk masyarakat.

\subsection{Pemegang Kekuasaan Pengelolaan Keuangan Daerah}

Kepala daerah selaku kepala pemerintah daerah adalah pemegang kekuasaan pengelolaan keuangan daerah dan mewakili pemerintah daerah dalam kepemilikan kekayaan daerah yang dipisahkan Pemegang kekuasaan pengelolaan keuangan daerah mempunyai kewenangan. Sehingga dari pemrintah pusat yaitu presiden sebagai kekuasaan pemerintah keuangan negara yang paling tinggi 
menyerahkan sebagai bentuk penerpaan adanya sistem desentralisasi kepada Gubernur dan Bupati atau walikota memiliki otoritas dan tanggung jawab atas pengelolaan keuangan daerahnya: Menetapkan kebijakan tentang pelaksanaan anggaran pendapatan dan belanja daerah (APBD):

a. Menetapkan kebijakan tentang pengelolaan barang daerah;

b. Menetapkan kuasa pengguna anggaran/pengguna barang;

c. Menetapkan bendahara penerimaan dan/atau bendahara pengeluaran;

d. Menetapkan pejabat yang bertugas memungut penerimaan daerah;

e. Menetapkan pejabat yang bertugas mengelola utang dan piutang daerah;

f. Menetapkan pejabat yang bertugas mengelola barang milik daerah; dan

g. Menetapkan pejabat yang bertugas menguji tagihan dan memerintahkan pembayaran.

Sekretaris daerah selaku koordinator pengelolaan keuangan daerah membantu kepala daerah menyusun kebijakan dan mengkoordinasikan penyelenggaraan urusan pemerintahan daerah termasuk pengelolaan keuangan daerah Sekretaris Daerah selaku coordinator pengelolaan keuangan daerah mempunyai tugas koordinasi di bidang:

a. Penyusunan dan pelaksanaan kebijakan APBD;

b. Penyusunan dan pelaksanaan kebijakan pengelolaan barang daerah;

c. Penyusunan rancangan APBD dan rancangan perubahan APBD;

d. Penyusunan Rancangan Peraturan Daerah (Raperda) APBD, perubahan APBD, dan pertanggungjawaban pelaksanaan APBD; 
e. Tugas-tugas pejabat perencana daerah, pejabat pengelola keuangan daerah, dan pejabat pengawas keuangan daerah;

f. Penyusunan laporan keuangan daerah dalam rangka pertanggungjawaban pelaksanaan APBD.

Selain mempunyai tugas koordinasi, sekretaris daerah mempunyai tugas antara lain :

a. Memimpin TAPD (Tim Anggaran Pemerintah Daerah),

b. Menyiapkan pedoman pelaksanaan APBD,

c. Menyiapkan pedoman pengelolaan barang daerah,

d. Memberikan persetujuan pengesahan dokumen pelaksanaan anggaran (DPA-SKPD)/dokumen perubahan pelaksanaan anggaran (DPPA), dan

e. Melaksanakan tugas-tugas koordinasi pengelolaan keuangan daerah lainnya berdasarkan kuasa yang dilimpahkan oleh kepala daerah.

Koordinator pengelolaan keuangan daerah bertanggungjawab atas pelaksanaan tugastugas tersebut kepada kepala daerah.

\subsection{Pejabat Pengelola Keuangan Daerah}

Kepala SKPKD selaku PPKD mempunyai tugas:

a. Menyusun dan melaksanakan kebijakan pengelolaan keuangan daerah,

b. Menyusun rancangan APBD dan rancangan perubahan APBD,

c. Melaksanakan pemungutan pendapatan daerah yang telah ditetapkan dengan peraturan daerah,

d. Melaksanakan fungsi bendahara umum daerah (BUD),

e. Menyusun laporan keuangan daerah dalam rangka pertanggungjawaban pelaksanaan APBD, dan 
f. Melaksanakan tugas lainnya berdasarkan kuasa yang dilimpahkan oleh kepala daerah.

g. PPKD selaku BUD menunjuk pejabat di lingkungan satuan kerja pengelola keuangan daerah selaku kuasa bendahara umum daerah (Kuasa BUD). PPKD mempertanggungjawabkan pelaksanaan tugasnya kepada kepala daerah melalui sekretaris daerah.

Penunjukan kuasa BUD oleh PPKD ditetapkan dengan keputusan kepala daerah Kuasa BUD mempunyai tugas:

a. Menyiapkan anggaran kas;

b. Menyiapkan SPD;

c. Menerbitkan Surat Perintah Pencairan Dana (SP2D);

d. Menyimpan seluruh bukti asli kepemilikan kekayaan daerah;

e. Memantau pelaksanaan penerimaan dan pengeluaran APBD oleh bank dan/atau lembaga keuangan lainnya yang ditunjuk;

f. Mengusahakan dan mengatur dana yang diperlukan dalam pelaksanaan APBD;

g. Menyimpan uang daerah;

h. Melaksanakan penempatan uang daerah dan mengelola /menatausahakan investasi daerah;

i. Melakukan pembayaran berdasarkan permintaan pejabat pengguna anggaran atas beban rekening kas umum daerah;

j. Melaksanakan pemberian pinjaman atas nama pemerintah daerah;

k. Melakukan pengelolaan utang dan piutang daerah; dan

I. Melakukan penagihan piutang daerah.

PPKD selaku BUD menunjuk pejabat di lingkungan satuan kerja pengelola keuangan daerah selaku kuasa bendahara umum daerah (Kuasa BUD). PPKD mempertanggungjawabkan pelaksanaan tugasnya kepada kepala daerah melalui sekretaris daerah. 
Penunjukan kuasa BUD oleh PPKD ditetapkan dengan keputusan kepala daerah Kuasa BUD mempunyai tugas:

a. Menyiapkan anggaran kas;

b. Menyiapkan SPD;

c. Menerbitkan Surat Perintah Pencairan Dana (SP2D);

d. Menyimpan seluruh bukti asli kepemilikan kekayaan daerah;

e. Memantau pelaksanaan penerimaan dan pengeluaran APBD oleh bank dan/atau lembaga keuangan lainnya yang ditunjuk;

f. Mengusahakan dan mengatur dana yang diperlukan dalam pelaksanaan APBD;

g. Menyimpan uang daerah;

h. Melaksanakan penempatan uang daerah dan mengelola /menatausahakan investasi daerah;

i. Melakukan pembayaran berdasarkan permintaan pejabat pengguna anggaran atas beban rekening kas umum daerah;

j. Melaksanakan pemberian pinjaman atas nama pemerintah daerah;

k. Melakukan pengelolaan utang dan piutang daerah; dan

I. Melakukan penagihan piutang daerah.

\subsection{Proses Perencanaan dan Penganggaran Keuangan Daerah}

Setiap daerah memiliki kebutuhan yang berbeda, namun setiap daerah harus memiliki RPJMD. Dimana RPJPD digunakan sebagai pedoman Kepala Daerah untuk menjalankan tugasnya. RPJPD sendiri merupakan kepanjangan dari Rencana Pembangunan Jangka Panjang Daerah yang dievaluasi dan digunakan untuk 20 tahun kedepan. Namun RPJPD tidak dibuat dengan seenaknya, RPJPD yang dibuat harus mengacu pada Rencana Pembangunan Jangka Panjang Negara untuk mencapai tujuannya. Dengan RPJPD tersebut, Pemerintah Daerah dapat merencakan Rencana Pembangunan Jangka Menengah Daerah (RPJMD) sebagai turunan atau penjabaran dari RPJPD yang 
berlaku dengan masa 5 tahun sekali. Tidak hanya itu, agar dapat mencapai tujuan setiap daerah, pemerintah Daerah harus membuat kerangka kerja yang lebih konkrit dan nyata yang dapat dikerjakan dan dievaluasi setiap tahunnya. Hal tersebut merupakan RKPD yaitu Rencana Kerja Pendek Daerah. Dapat dijelaskan bahwa setiap daerah mempunyai dokumen dalam pelaksanaan tugas dan penganggaran keuangan daerah berupa dokumen RKPD setiap satu tahun sekali yang mengacu pada RPJMD, dan RPJMD setiap 5 tahun sekali yang mengacu pada RPJPD, dan RPJPD yang digunakan sebagai pedoman dalam membangun daerah selama 20 tahun sekali yang mengacu pada kerangka kerja nasional yaitu RPJPN.

Setelah semua dokumen terselesaikan, kepala daerah selaku pemimpin dari pemerintah daerah mengundang dan membahas rencana tersebut dalam rangka rapat peraturan daerah mengenai APBD dengan DPRD. Sehingga DPRD dan pemerintah daerah menyetujui rancangan dalam RAPERDA APBD tersebut menjadi PERDA APBD yang kemudian dapat dianggarkan untuk kebutuhan daerah. Sebelum merencanakan APBD tim penyusun APBD harus mempunyai prinsip-prinsip penyusunan APBD diantaranya harus sesuai dengan kebutuhan penyelenggaraan Pemerintah Daerah berdasarkan urusan dan kewenangannya; tertib, taat pada ketentuan peraturan perundang-undangan; tepat waktu dalam merencanakan dan melaksanakan; transparan; partisipatif; serta tidak bertentangan dengan kepentingan umum, dan peraturan yang lebih tinggi.

\subsection{Pelaksanaan Anggaran Pendapatan dan Belanja Daerah}

\section{(APBD)}

Anggaran pendapatan dan Belanja Daerah atau yang sering disebut dengan APBD adalah suatu perencanaan keuangan pada pemerintahan daerah yang dimusyawarahkan dan disepakati bersama oleh Pemerintah Daerah dan Dewan Perwakilan Rakyat Daerah (DPRD) yang kemudian ditetapkan dengan suatu peraturan 
daerah yang dilaksanakan pada tiap tahunnya. Dalam menyusun APBD hendaknya mempunyai asas umum yang diterapkan yaitu dalam hal penyusunan APBD, Pemerintah daerah harus menyelenggarakan kebutuhannya berdasarkan kemampuan pendapatan daerah. Pelaksanaan belanja daerah harus didasrkan apda prinsip hemat, tidak mewah (sederhana) efektif, efesien dan seseuai ketentuan perundang-undangan. Selain itu APBD mempunyai fungsi otorisasi, perencanaan, pengawasan, alokasi, distribusi, dan stabilisasi. Maka dapat dikatakan bahwa semua pengeluaran atau belanja daerah harus sesuai dengan kesepakatan APBD, tidak boleh melebihi atau menganggarkan yang bukan termasuk pada APBD. Sehingga dalam menyusun APBD, setiap anggaran yang dikeluarkan harus didukung dengan adanya kepastian dan ketersediaan sumber daya dalam penerimaan APBD dalam jumlah yang cukup. Selain itu setiap anggaran yang dikeluarkan dari APBD harus di support dengan regulasi yang mendasarinya.

Struktur APBD terdiri dari tiga komponen yaitu pendapatan daerah, belanja daerah dan pembiayaan daerah. Hal tersebut telah dijabarkan pada substansi sebelumnya. Namun dapat ditambahkan bahwasanya pembiayaan daerah yang terdiri dari adanyan penerimaan dan pengeluaran pembiayaan. Penerimaan yang disebutkan sebagaimana yang terdiri dari SILPA tahun anggaran sebelumnya, pencairan dana cadangan, hasil penjualan kekayaan daerah yang dipisahkan, penerimaan pinjaman dan penerimaan kembali pemberian pinjaman. Sedangkan yang dimaksud dari pengeluaran pembiayaan adalah semua kegiatan keuangan yang didapatkan dari pembentukan dana cadangan, penyertaan modal pemerintah daerah, pembayaran pokok utang dan pemberian pinjaman.

Dokumen-dokumen yang harus disiapkan oleh Satuan Kerja Perangkat Daerah (SKPD) dalam menggarkan keuangan daerah 
adalah dokumen mengenai rancangan DPA-SKPD yang memiliki substansi dan perincian mengenai sasaran yang akan dicapai, fungsi penganggaran tersebut, program yang dianggarkan, kegiatan yang dilaksanakan dalam anggaran, seberapa besar anggaran yang disiapkan untuk sasaran tersebut dan rencana pendapatan yang diperkirakan. Dokumen-dokumen tersebut diserahkan oleh Kepala SKPD kepada PPKD dengan masa maksimal 6 hari kerja setelah pemberitahuan dalam penyusunan dokumen.

\subsection{Kebijakan Penganggaran Terkait Anatomi Belanja dalam}

APBD

Kerangka kebijakan anggaran pembelanjaan daerah berdasarkan empat golongan belanja yaitu belanja yang diarahkan (earmark), belanja yang bersifat wajib dan mengikat, belanja yang ditentukan prosentasenya sesuai amanat perundang-undangan dan belanja pemenuhan urusan sesuai SPM. Bentuk-bentuk belanja yang diarahkan dalam pemerinatahan daerah, diantaranya: DAK, DBH-DR, DBH Cukai/ hasil tembakau, Dana Otsus untuk program, Dana BOS, Dana Insentif Daerah, Dana Penyesuaian (Tunjangan fungsional, tambahan penghasilan dll), serta bantuan keuangan yang bersifat khusus.

Sedangkan kegiatan yang termasuk belanja yang bersifat mengikat atau wajib dapat dijabarkan diantaranta belanja pegawai, belanja bunga, kegiatan DPA-L, Dukungan program prioritas nasional seperti contoh Dana Pendamping DAK, dan belanja program atau kegiatan yang bersifat rutin seperti keperluan kantor sehari-hari. Sedangkan untuk belanja yang ditentukan prosentasenya sesuai amanat perundang-undangan dapat dijabarkan seperti kegiatan belanja fungsi pendidikan sebesar $20 \%$ dari total belanja, belanja urusan kesehatan sekurang-kurangnya $10 \%$ dari total belanja diluar gaji, alokasi dana desa (ADD) sebesar $10 \%$ dari dana perimbangan, 
bagi hasil kabupaten atau kota kepada desa minimal 10\%, dan lain sebagainya.

Selain hal tersebut ada kegiatan yang dimasukkan kedalam golongan belanja untuk pemenuhan urusan sesuai SPM yaitu semua kegiatan pembelanjaan urusan wajib yang berkaitan dengan pelayanan dasar seperti pendidikan, kesehatan, pekerjaan umum \& penataan ruang, perumahan rakyat \& Kawasan permukiman, ketentaraman \& ketertiban umum serta perlindungan masyarakat dan urusan kegiatan sosial. Perlu dikatahui bahwasanyaa pembinaan dan pengawasan dalam pengelolaan keuangan daerah berada dibawah Menteri Dalam Negeri dan Gubernur.

\section{Quiz}

Kota Jayapura sebagai salah satu daerah bagian dari Provinsi Papua yang merasakan langsung kekhususan dalam pengelolaan bidang pemerintahan dan bidang fiskal sebagaimana yang diamanatkan dalam Otonomi Daerah (OTDA) dan Otonomi Khusus (OTSUS) di Papua. Implementasi Pelaksanaan OTDA dan OTSUS mengharuskan pemerintah daerah Kota Jayapura untuk menentukan prioritas program dan perencanaan pembangunan daerah dan kewenangan untuk mengatur dan mengurus daerahnya serta mampu menggali sumber-sumber keuangan untuk memenuhi kebutuhan pembiayaan pemerintahan dan pembangunan daerahnya.

Pemberian otonomi khusus didukung oleh dengan bantuan dana. Selama 2008-2018 Pemerintah pusat telah mengucurkan dana 98 triliun, ditambah dengan bagi hasil minyak dan gas sehingga total 105 triliun untuk Papua. Pembangunan infrastruktur di Papua juga gencar dilakukan Pemerintah Pusat. Namun usaha pemerintah belum mampu menyelesaikan permasalahan yang ada. 
Masalah paling krusial di tanah Papua adalah kualitas sumber daya manusia. Indeks Pembangunan Manusia di Papua adalah yang paling rendah di Indonesia. Selain itu, pertikaian antar kelompok yang masih sering terjadi membuat keadaan di Papua tidak kondusif. Ditambah dengan diskriminasi yang masih terjadi terhadap orang Papua membuat mereka minim kepercayaan terhadap NKRI. (VOA Indonesia, 10 September 2019_Penulis : Fathiyah Wardah)

\section{Studi Kasus}

Pelaksanaan Otonomi Khusus di Papua Dinilai Gagal

\section{Versi terbaru per: 10/09/2019}

Fathiyah Wardah

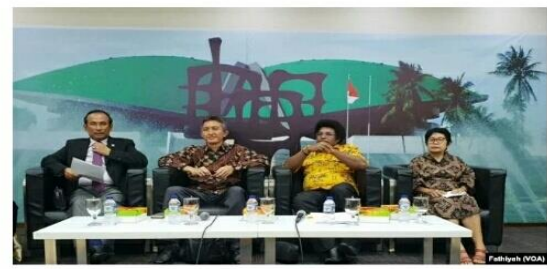

Diskusi mengenai otonomi khusus Papua di Jakarta, Selasa, 10 September 2019. (Foto: VOA/Fathiyah)

Berdasarkan uraian diatas, Jawablah beberapa pertanyaan berikut: 
1) Menurut pendapat Saudara, mengapa bantuan dana dan pembangunan infrastruktur belum efektif untuk menyelesaikan permasalahan di Papua!

2) Deskripsikan pendapat Saudara, bagaimana pendekatan yang harus dilakukan pemerintah pusat untuk meningkatkan semua aspek pembangunan di Papua?

3) Papua adalah provinsi yang terkenal dengan sumber daya alam yang melimpah. Bagaimana peran masyarakat Papua dalam mengelola sumber daya alam untuk meningkatkan pendapatan daerah! Berikan contohnya!

\section{E. Simpulan}

Hal penting lainya untuk pemerintahan daerah adalah perihal keuangan. Keuangan dianggap dapat memperlancar suatu pembangunan atau kebijakan yang direncanakan oleh pemimpin daerah. Oleh karena itu, hendaknya keuangan dapat diperoleh dengan jelas sesuai aliran keuanganya. Keuangan daerah dapat diperoleh dari tiga sumber yaitu sumber dana yang berasal dari Pendapatan Asli Daerah (PAD), sumber dana perimbangan dan dana pendapatan lainnya yang sah. Pendapatan asli daerah sendiri didapatkan oleh pemerintah daerah melalui peraturan-peraturan daerah yang dibuat, misalkan parkir berlangganan. Dana perimbangan merupakan dana yang disiapkan oleh pemrintah pusat untuk membantu keuangan pemerintah daerah. Hal tersebut dapat dimisalkan dengan sumber dana bagi hasil pajak, bagi hasil non pajak, dana alokasi umum (DAU), dan dana alokasi khusus (DAK). Sedangkan sumber pendapatan lainnya yang sah adalah pendapatan yang bersumber berdasarkan komisi, pendapatan bunga dan lain sebagainya. Untuk memproses keungan yang jelas dalam pengganggaran perencanaan suatu pembangunan atau kebijakan, pemerintah daerah harus membuat Rancangan Anggaran 
Pendapatan Belanja Daerah (RAPBD) yang kemudian dapat dicairkan dan disahkan dengan adanya Anggaran Pendapatan Belanja Daerah (APBD). Segala prosesnya dapat dijelakan dalam bab ini, sehingga mahasiswa akan mampu menguraikan bagaimana keuangan daerah dialokasikan dan bagaimana proses yang dilaluinya.

\section{F. Daftar Pustaka}

Bratakusumah, D. S. \& Solihin, D. (2004). Otonomi penyelengaraan pemerintahan daerah. Jakarta: Gramedia Pustaka Utama.

Husroh, A. D. (1990). Ilmu Negara. Jakarta: Bumi Aksara.

Muluk, Khairul, M.R. 2009. Peta konsep desentralisasi \& pemerintahan daerah. Surabaya:ITS Press.

Syamsuddin, H. (2007). Desentralisasi dan otonomi daerah: Desentralisasi, demokratisasi, dan akuntabilitas pemerintahan daerah. Jakarta: LIPI Press. 


\section{DAFTAR PUSTAKA}

Abdurrahman. (1987). Beberapa Pemikiran Tentang Otonomi Daerah. Jakarta: Media Sarana Press.

Andriansyah. (2015). Administrasi pemerintahan daerah dalam analisa. Jakarta: FISIP Universitas Prof. Dr. Moestopo Beragama.

Arenawati. (2014). Administrasi pemerintahan daerah: Sejarah konsep dan pelaksanaan di Indonesia. Yogyakarta: Graha IImu.

Budiardjo, M. (1991). Dasar-Dasar Ilmu Politik. Jakarta: Gramedia Pustaka.

Bratakusumah, D. S. \& Solihin, D. (2004). Otonomi penyelengaraan pemerintahan daerah. Jakarta: Gramedia Pustaka Utama.

Chalid, P. (2005). Otonomi Daerah : Masalah, Pemberdayaan dan Konflik. Jakarta: Kemitraan.

Cheema, G. S., \& Rondinelli, D. A. (1992). Decentralization and Development, Policy Implementation in Developing Countries. London/New Dehli: Sage Publication/Baverly Hills.

Cohen, J. M., \& Peterson, S. B. (1999). Administrative Desentralization. USA: Kumarian Perss.

Haris, S. (2007). Desentralisasi dan Otonomi Daerah : Desentralisasi, Demokrasi, dan Akuntabilitas Pemerintah Daerah. Jakarta: LIPI Press. 
Husroh, A. D. (1990). Ilmu Negara. Jakarta: Bumi Aksara.

Huda, N. (2005). Otonomi daerah filosofi, sejarah perkembangannya, dan problematikanya. Yogyakarta: Pustaka Pelajar.

Ichsan, Supriyono, \& Muluk. (2006). Variasi Cakupan dan Peran Pelayanan Publik Pemerintah Derah. Malang: Kerjasama LPM Unibraw dan Bappenas.

Imawan, R. (2004). Desentralisasi, Demokratisasi, dan Pembentukan Good Governance. Jakarta: LIPI Press.

Isjwara, F. (1974). Pengantar Ilmu Politik. Bandung: Bina Cipta.

Joeniarto. (1992). Perkembangan Pemerintahan Lokal. Jakarta : Bumi Aksara.

Kaputra, I., dkk. (2013). Dampak otonomi daerah di Indonesia: Merangkai sejarah poitik dan pemerintahan Indonesia. Jakarta: Yayasan Pustaka Obor Indonesia.

Koesoemahatmadja, R. (1979). Pengantar Kearah Sistem Pemerintahan Daerah Di Indonesia. Bandung: Bina Cipta.

Lapera, T. (2001). Otonomi Pemberian Negara, Kajian Kritis Atas Kebijakan Otonomi Daerah. Jakarta: Lapera Pustaka Utama.

Mawhood, P. (1983). Local Government in The Third World. Chicester, UK: John Wisley and Sons.

Muluk, M. R. (2006). Desentralisasi dan Pemerintah Daerah . Jakarta: Bayumedia. 
Muluk, K. M.R. (2007). Menggugat partisipasi publik dalam pemerintahan daerah. Malang: Bayumedia Publishing.

Muluk, Khairul, M.R. 2009. Peta konsep desentralisasi \& pemerintahan daerah. Surabaya:ITS Press.

Muslimin, A. (1986). Aspek-Aspek Hukum Otonomi Daerah. Bandung: Alumni.

Nasution, A. B. (2000). Federalisme Untuk Indonesia. Jakarta: Kompas.

Nurcholis, H. \& Ittihad, A. Z. (2010). Administrasi pemerintahan daerah. Jakarta: Universitas Terbuka.

Riwu, J. (2008). Prospek Otonomi Daerah di Negara Republik Indonesia . Jakarta: PT. Raja Grafindo Perkasa.

Rodinelli. (1983). Implementing Decentralization Programmes In Asia : A Comparative Analysis. Public Administration and Development, Vol. 3.

Rondinelli. (1990). Decentralization, Territorial Power and The State : A Critical Response. Development and Change, Vol. 21. 
Rondinelli, Nellis, \& Cheema. (1983). Decentralization in Developing Countries : A Review of Recent Experience. Washington: The World Bank.

Rosidin, U. (2010). Otonomi daerah dan desentralisasi. Bandung: Pustaka Setia.

Syamsuddin, H. (2007). Desentralisasi dan otonomi daerah: Desentralisasi, demokratisasi, dan akuntabilitas pemerintahan daerah. Jakarta: LIPI Press.

Said. (2005). Arah Baru Otonomi Daerah di Indonesia. Malang: UMM.

Seymour, \& Truner. (2002). Otonomi Daerah : Indonesia's Decetralisation Experiment. New Zealand Journal of Asian Studies 4, Vol. 2.

Slater. (1990). Debating Decentralisation - A Reply to Rondinelli. Development and Change Vol. 21.

Soemantri, S. (1981). Pengantar Perbandingan Antar Hukum Tata Negara. Jakarta: Rajawali.

Sujito, I. (1990). Hubungan Pemerintah Pusat dan Pemerintah Daerah. Jakarta: Rineka Cipta.

Surianingrat, B. (1981). Desentralisasi dan Dekonsentrasi Pemerintah di Indonesia, Suatu Analisa. Jakarta: Dewaruci Perss. 
Utrecht, E. (1966). Pengantar dalam Hukum Indonesia. Jakarta: Ichtiar.

Undang-Undang No. 32 Tahun 2004 Tentang Pemerintahan Daerah. 


\section{BIODATA PENULIS}

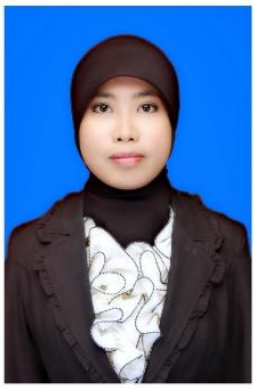

Ilmi Usrotin Choiriyah, M.AP dilahirkan di Malang, 12 Agustus 1990. Pada tahun 2012, penulis mendapatkan gelar Sarjana Administrasi Publik dari Universitas Brawijaya. Penulis melanjutkan Magister double degree dengan beasiswa fast track kerjasama dari Universitas Brawijaya dengan Burapha University, Thailand. Tahun 2014, penulis secara resmi mendapatkan gelar M.AP (Magister Administrasi Publik) dan M.Pol.Sc. (Master of Political Scince and Law). Penulis mengawali karirnya sebagai Dosen di Prodi Administrasi Publik Universitas Muhaammdiyah Sidoarjo. Beberapa penelitian yang pernah dilakukan oleh penulis adalah hibah dari Ristek Dikti dengan skeme dosen pemula pada tahun 2016, hibah institusi tahun 2016 dan 2017, serta hibah dari pemkab Sidoarjo sejak tahun 2015-2018. Selain itu, pengabdian masyarakat yang pernah dilakukan oleh penulis adalah hibah institusi tahun 2016 dan hibah pemkab Sidoarjo tahun 2016-2017.

Lailul Mursyidah, M.AP. dilahirkan di Sidoarjo, 25 Juni 1990. Pada tahun 2011, penulis mendapatkan gelar Sarjana IImu Administrasi Publik dari Universitas Brawijaya Malang. Pada tahun 2012 penulis menerima Beasiswa Unggulan BPKLN dari Kementerian Pendidikan dan Kebudayaan untuk melanjutkan Studi Magister IImu

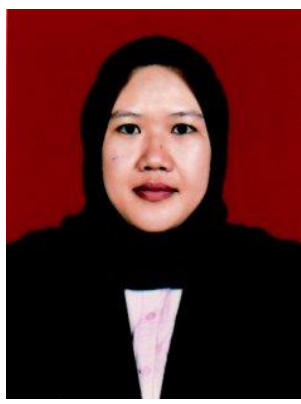
Administrasi Publik di Universitas Brawijaya Malang dengan Program Double Degree/Joint Degree. Tahun 2014, penulis secara resmi 
mendapatkan gelar M.AP. Penulis mengawali karirnya sebagai Dosen di Program Studi Administrasi Publik Universitas Muhammadiyah Sidoarjo dengan Bidang Keahlian Manajemen dan Pelayanan Publik. Selain pendidikan dan pengajaran penulis juga terlibat dalam kegiatan penelitian dan pengabdian kepada masyarakat baik didanai oleh Pemerintah, Ristekdikti maupun dana mandiri. Penulis juga aktif dalam mengikuti kegiatan-kegiatan penunjang akademik seperti seminar, workshop/ lokakarya, pelatihan serta pembimbingan tugas akhir dan kegiatan akademik. 